\title{
Platinum-Group Elements in
}

\section{Sedimentary Environments in the}

Conterminous United States

\section{U.S. GEOLOGICAL SURVEY BULLETIN 2049-A}

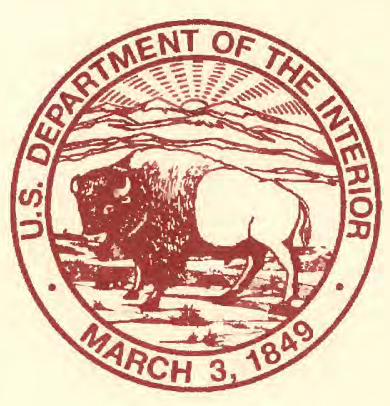





\section{Platinum-Group Elements in Sedimentary Environments in the Conterminous United States}

By Jocelyn A. Peterson

With a section on Platinum-Group Elements in Coal By Robert B. Finkelman and Susan J. Tewalt

GEOLOGY AND GEOLOGIC ENVIRONMENTS PERMISSIVE FOR PLATINUM-GROUP ELEMENTS IN THE CONTERMINOUS UNITED STATES

Michael L. Zientek and Norman J Page, Scientific Editors

U.S. GEOLOGICAL SURVEY BULLETIN 2049-A

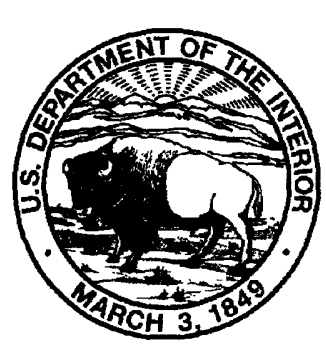

UNITED STATES GOVERNMENT PRINTING OFFICE, WASHINGTON : 1994 


\title{
U.S. DEPARTMENT OF THE INTERIOR \\ BRUCE BABBITT, Secretary
}

\author{
U.S. GEOLOGICAL SURVEY \\ Gordon P. Eaton, Director
}

For sale by

U.S. Geological Survey, Map Distribution

Box 25286, MS 306, Federal Center

Denver, CO 80225

Any use of trade, product, or firm names in this publication is for descriptive purposes only and does not imply endorsement by the U.S. Government.

Library of Congress Cataloging-in-Publication Data

Peterson, Jocelyn A.

Platinum-group elements in sedimentary environments in the conterminous United States / by Jocelyn A. Peterson ; with a section on platinum-group elements in coal by Robert B. Finkelman and Susan J. Tewalt.

p. cm. - (U.S. Geological Survey bulletin ; 2049) (Geology and geologic environments permissive for platinum-group elements in the conterminous United States ; ch. A)

Includes bibliographical references.

Supt. of Docs. no. : I 19.3:2049-A

1. Platinum ores-United States. 2. Placer deposits-United States. 3. Sedimentary basins-United States. I. Title. II. Series. III. Series: Geology and geologic environments permissive for platinum-group elements in the conterminous United States; ch. A.

QE75.B9 no. 2049

[Tn490.P7]

$557.3 \mathrm{~s}-\mathrm{dc} 20$

[553.4'22'0973] 


\section{PREFACE}

Advances in the understanding of the geochemistry of the platinum-group elements (PGE), the recognition of the diversity of environments in which they are found, and unsettled economic and political conditions throughout the world indicating a need for reliable sources of PGE have together resulted in this assessment of environments favorable for the occurrence of deposits within the United States that may contain PGE resources. A preliminary assessment delineated possible conventional and unconventional environments for the occurrence of PGE-bearing deposits (Zientek and others, 1988). This series of publications expands, refines, and provides documentation for the material presented in that preliminary report. In these reports we present descriptive deposit models that include PGE-related data, tables to augment mapped information, detailed maps of conventional and unconventional environments where PGE may be present in the conterminous United States, and a substantial bibliography documenting the background material used to produce these maps.

This compilation delineates environments in which PGE may be concentrated. To spatially define and to illustrate those environments on a series of maps, deposits and occurrences that are known to have concentrated PGE were identified. These include deposits known to have produced PGE, either as the principal commodity or as a byproduct of mining other metals, based on a review of worldwide information. Also, deposits with analytical data indicating the presence of PGE, but for which there is no recorded production, were identified. Some of the latter deposits may contain relatively high concentrations of PGE (for example, in unconformity uranium-gold or Olympic Peninsula-type volcanogenic manganese deposit types), whereas others have lower PGE levels that could only be exploited as a byproduct. A review of the geologic characteristics and geochemical associations of additional deposit types allowed them to be identified as permissive for the occurrence of PGE even though no production or analytical information is available.

In some cases, these permissive environments corresponded to descriptive models such as those presented in Cox and Singer (1986). These descriptive models generally have several parts; the first outlines the environments in which the deposit types are found and the second identifies specific characteristics of the deposit type. If enough data are available, grade-tonnage distributions, which provide quantitative information on the sizes and grades for deposits of a given type, are provided. We have augmented these published models with production and analytical information on PGE, if these data are not available in the published model, or we presented the factors that led us to believe PGE may be present in those types of deposits. For some deposit types for which there are PGE data that have not been included in the original model and which we view as being important, the models in Cox and Singer (1986) were greatly expanded and revised. If no descriptive model was available for a deposit type we recognized, we attempted to develop one.

Deposit types permissive for PGE classified by the geologic environment in which they are found

[Models numbers from Cox and Singer (1986), Bliss (1992), and Mosier and Page (1988) are shown in parentheses. Entries preceded by asterisk have recorded production of PGE; those that are italicized have concentrations that may exceed 1 ppm PGE]

Deposits associated with convergent plate margins

Deposits associated with allochthonous mafic and ultramafic rocks:

*Acoje ophiolitic nickel-copper

Limassol Forest cobalt-nickel (8c)

Podiform chromite (8a)

Other magmatic deposits:

*Alaska PGE (9)

* Syenite-hosted copper-silver-PGE

*Synorogenic-synvolcanic nickel-copper (7a)

Deposits hosted in sedimentary rocks:

Southeast Missouri lead-zinc (32a)

Carbonate-hosted gold-silver (26a)

Porphyry-related deposits:

*Porphyry copper (17)

*Volcanic-hosted copper-arsenic-antimony (22a)

Gold-bearing skarns (?)

Epithermal quartz-alunite gold (25e)

Other hydrothermal deposits:

*New Rambler copper-gold-PGE

Olympic Peninsula-type volcanogenic manganese (24c.3)

Hot-spring gold-silver (25a)

Hot-spring mercury (27a)

Kuroko massive sulfide (28a)

Low-sulfide gold-quartz veins (36a)

Polymetallic veins $(22 \mathrm{c})$

Residual or placer deposits:

*Placer gold-PGE (39a) and *PGE-gold (39b)

Lateritic nickel (38a)
Deposits associated with intracontinental rifts, anorogenic settings, and Proterozoic to Archean greenstone belts

Residual or placer deposits:

*Quartz-pebble conglomerate uranium-gold (29a)

Magmatic deposits:

* Bushveld chromium (2a)

*Dunitic nickel-copper (6b)

*Komatiitic nickel-copper (6a)

*Merensky Reef PGE (2b)

*Noril'sk copper-nickel-PGE (5b)

Duluth copper-nickel-PGE (5a)

Anorthosite titanium (32)

Bushveld iron-titanium-vanadium (3)

Stillwater nickel-copper (1)

Deposits hosted in sedimentary rocks:

*Sediment-hosted copper (30b)

Blackbird cobalt-copper (24d)

Solution-collapse breccia pipe uranium (32e)

Deposits associated with alkaline magmatism:

*Carbonatite deposits (10)

Syenite/gabbro-hosted copper-silver-PGE

Gold-silver-tellurium veins (22b)

Diamond pipes (12)

Other deposit types:

Basaltic copper (23)

Unconformity uranium-gold (37a)

Homestake gold (36b)

Deposits not restricted to any particular setting

Metalliferous black shales

Coal 
For certain ore deposit types, we found that the descriptive models were based on a single deposit or district and therefore lacked grade-tonnage distributions. Use of these very depositspecific models ignored the underlying geologic processes that could result in the formation of similar deposits in very different geologic settings from those in the descriptive model. This is particularly true for magmatic ore deposits. Although it is difficult to group enough deposits together with enough shared characteristics to construct descriptive models with grade-tonnage distributions, it was possible to describe the general environments and processes that may lead to the concentration of PGE, which we will refer to as lithotectonic terrane models. Descriptive and process-oriented summaries of magmatic sulfide and magmatic oxide deposits were used in conjunction with the lithotectonic terrane models to indicate permissive settings for deposits. Examples of deposits are summarized for each lithotectonic terrane model. For magmatic deposit types that have enough shared characteristics and many examples, conventional deposit models and grade-tonnage information are also presented.

The general geologic environments presented in the models were used to define the tracts depicted on the maps. The data and lithologic map boundaries were compiled from many sources at various levels of detail. Most of the information came from published literature but some came from conversations with experts on specific areas; only a few areas have been investigated in detail in the field by one or more of us. Considerable personal interpretation and decision making was necessary to resolve inconsistencies, contradictions, and controversies.

Maps showing permissive areas for the various deposit types were prepared at scales of 1:2.5 million, 1:7.5 million, and 1:17 million, depending upon the degree of detail needed to show the information. The general approach was to compile as many environments as possible in as much detail as possible on the large-scale map. Compilations for some of the environments were subsequently reduced to smaller scales. Most of the sedimentary environments are shown at the intermediate scale. This does not necessarily mean that they are less important, but the available information was easily shown at the smaller scale. For some environments, particularly those for which large areas are permissive for deposits of those types and little detailed informa- tion about abundance or distribution of PGE in the deposits is available, it was impractical to try to define tracts except as very generalized areas on page-sized illustrations.

Crocket (1981) provided some general ranges of concentrations of PGE in unmineralized rocks, which indicates a range of 1 to the low tens of parts per billion in ultramafic rocks, tenths to the low tens of parts per billion in mafic rocks with more variability than in ultramafic rocks, and thousandths to less than 10 parts per billion (ppb) in intermediate and felsic rocks. To form an ore body that could be exploited principally for its PGE content, PGE must be concentrated many times over crustal abundances to concentrations well in excess of 5 parts per million (ppm); however, when present with other valuable metals that are mined and processed in such a way that the PGE are concentrated, PGE can be recovered from rocks with concentrations of $1 \mathrm{ppb}$ or less.

The text in this series contains deposit models; explanatory information concerning tracts shown on the maps; tables listing the specific tracts depicted on the maps and information about those tracts, including specific references used in defining the tracts; and a reference list. The reference list includes specific references used in constructing the maps and in developing the deposit models contained in this series. This includes state and topical geologic maps used in drawing specific tracts. In addition, other literature which is not specifically cited, but which provided insight into concepts for certain deposit types, is included. However, this list is not meant to be a comprehensive list for all deposit types discussed here, so in some cases, significant papers on a given topic may not be included.

Identifying permissive areas for a given deposit type on the basis of favorable geologic characteristics is only the first step in conducting a quantitative mineral resource assessment. In addition to being able to establish favorable areas, grade-tonnage models are required, along with an estimate of the number of deposits that could be present. Unfortunately, it is currently only possible to show permissive areas and known PGE occurrences within those areas because, for most deposits and occurrences that have enough shared characteristics to be considered together as a deposit type, there simply is not enough information, particularly about PGE, to construct grade-tonnage models. In addition, without grade-tonnage models, estimates of the number of deposits in a given geologic environment cannot be made. 


\section{CONTENTS}

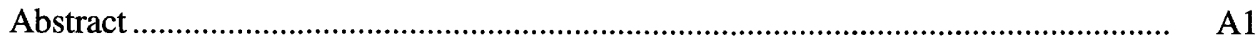

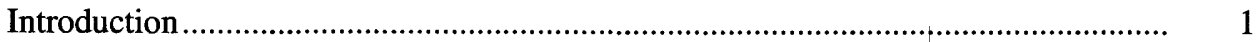

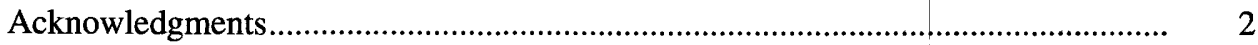

Deposit models ........................................................................................................ 2

Placer deposits ....................................................................................... 2

Regional setting .............................................................................. 2

Local setting of ore deposits ..................................................................... 2

Description of deposits ............................................................................... 3

Economic considerations .............................................................................. 3

Sediment-hosted (redbed) copper deposits ........................................................... 4

Regional setting ……............................................................................. 4

Local setting of ore deposits ..................................................................

Description of copper deposits.................................................................. 4

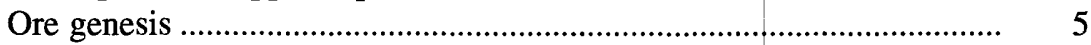

Economic considerations ........................................................................ 6

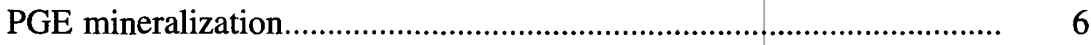

Metalliferous black shales .......................................................................... $\quad 7$

Regional setting ................................................................................. 7

Metal enrichment ..................................................................... 7

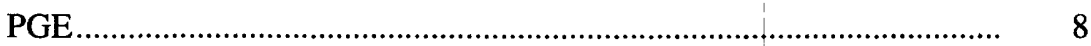

Unconformity uranium-gold deposits ......................................................

Quartz-pebble conglomerate gold-uranium deposits .......................................... 9

Regional setting .................................................................................. 9

Local setting of ore deposits ................................................................. 9

Description of deposits..................................................................... 10

Economic considerations ................................................................ 10

PGE mineralization...................................................................... 10

Blackbird cobalt-copper deposits............................................................... 11

Southeast Missouri lead-zinc deposits ..................................................... 11

Solution-collapse breccia pipe uranium deposits ............................................. 11

Platinum-group elements in coal, by R.B. Finkelman and S.J. Tewalt...................... 12

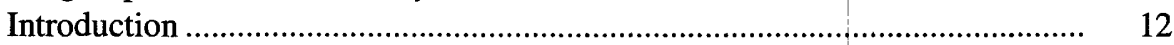

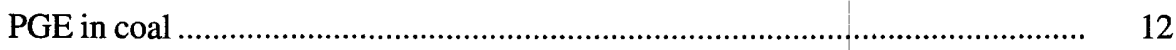

Rationale for PGE-coal basins map (fig. 1) ................................................. 14

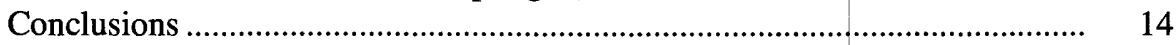

Discussion of tract designations for PGE in sedimentary environments ................... 14

Placer areas (map 1, pl. 1) .................................................................... 15

Sediment-hosted copper tracts (map 1, pl. 1) ……....................................... 15

Midcontinent region (tract 5, map 1) ................................................. $\quad 15$

Nonesuch Shale (tract 6, map 1) ............................................................. 21

New Mexico region (tract 7, map 1).................................................. 21

Belt Supergroup (tract 8, map 1) ........................................................ 21

Lisbon Valley (tract 9, map 1) ............................................................ 22

Mesozoic basins (tract 10, map 1) .......................................................... 22

Kona Dolomite (tract 11, map 1) ........................................................ 22

West Texas (tract 12, map 1)........................................................... 22

Catskill Formation (tract 13, map 1).................................................... 22

Northwestern New York (tract 14, map 1)............................................. 22 
Discussion of tract designations for PGE in sedimentary environments-Continued

Metalliferous black shale tracts (map 2, pl. 1).............................................. 22

Pennsylvanian shales of the Midwest (tract 4, map 2) ........................... 23

Shales of the eastern plains states (tract 6, map 2)............................... 23

Northern plains shales (tract 7, map 2)................................................. 23

Phosphoria Formation (tract 10, map 2) .................................................. 23

Green River Formation (tract 11, map 2) ............................................. 23

Kishenehn Formation (tract 12, map 2) .................................................. 23

Central Texas (tract 13, map 2) ............................................................... 23

Idaho shale belt (tract 14, map 2) ............................................................... 23

California Coast Ranges (tract 17, map 2) ............................................. 24

Klamath Mountains (tract 18, map 2) .................................................... 24

Apache Group (tract 19, map 2) ............................................................ 24

Atlantic and Gulf coastal plains (tract 20, map 2) ................................... 24

Unconformity uranium-gold tracts (fig. 2) ...................................................... 24

Quartz-pebble conglomerate gold-uranium tracts (map 1, pl. 1)....................... 24

Wyoming (tract 15, map 1) ................................................................... 26

Black Hills (tract 16, map 1).................................................................. 26

Michigan (tract 17, map 1) ................................................................. 26

Minnesota (tract 18, map 1) ................................................................ 26

Montana (tract 19, map 1) ................................................................... 26

Southern Idaho (tract 20, map 1) ....................................................... 26

Salt Lake region (tract 21, map 1) ..................................................... 26

Uinta Mountains (tract 22, map 1) ..................................................... 26

Blackbird cobalt-copper tract (tract 23, map 1) ................................................. 26

Southeast Missouri lead-zinc tract (tract 22, map 2) .......................................... 26

Solution-collapse breccia pipe uranium tract (tract 23, map 2) ......................... 27

Summary and conclusions ...................................................................................... 27

Selected references ....................................................................................... 27

Appendix. List of PGE-bearing minerals and their chemical compositions ........... 38

\section{PLATE}

[Plate is in pocket]

1. Permissive areas for platinum-group elements in the conterminous United States.

\section{FIGURES}

1. Coal basins in the conterminous United States and their favorability for platinum-group element enrichment ...... A13

2. Permissive tracts for unconformity uranium-gold deposits within the conterminous United States......................... 25

\section{TABLE}

1. List of and information about tracts for deposit types in the conterminous United States shown on maps 1 and 2 (pl. 1) and figure 2 


\title{
Platinum-Group Elements in Sedimentary Environments in the Conterminous United States
}

\author{
By Jocelyn A. Peterson
}

\section{ABSTRACT}

Platinum-group elements (PGE) have long been produced from placer deposits, particularly those in the Ural Mountains of Russia and in Colombia, and more recently as byproducts from mining of sediment-hosted copper deposits in the Kupferschiefer of Europe and the Copperbelt of central Africa and mining of quartz-pebble conglomerate golduranium deposits in the Witwatersrand of South Africa. Geochemical analyses of samples from other sedimentary environments including metalliferous black shales, coal, and unconformity uranium-gold terranes indicate the presence of small amounts of PGE. In addition, the geologic settings and geochemical suites within Blackbird cobaltcopper, southeast Missouri lead-zinc, and solution-collapse breccia pipe uranium deposits suggest that PGE may be present, but limited analyses to date have not found significant quantities. To gain a better understanding of the occurrence of PGE in these sedimentary environments, I present descriptive deposit models for each deposit type, based on those found in Cox and Singer (U.S. Geological Survey Bulletin 1693), that emphasize the characteristics of the occurrence of PGE or indicate that PGE might be present. The section on coal by R.B. Finkelman and S.J. Tewalt uses a factor analysis to determine the favorability of the coal basins in the conterminous United States for containing PGE and assigns a high favorability to parts of two basins in the midcontinent region, a medium favorability to parts of three basins in the Midwest and South and smaller basins scattered throughout the U.S., and a low favorability to the remaining basins. Discussions of the other sedimentary environments focus on the areas within the conterminous U.S. that are permissive for the occurrence of those environments and provide rationale for delineating each permissive tract. I have identified 4 main areas of placer occurrences; 10 areas for sediment-hosted copper deposits; 21 areas containing black shales, most of which are metalliferous; 7 areas permissive for unconformity uranium-gold deposits, although none have been identified; 8 areas of quartz-pebble conglomerates; 1 area of Blackbird cobalt-copper deposits and suggest that another major region is permissive for such
\end{abstract}

deposits; 1 area of southeast Missouri lead-zinc deposits; and 1 region of solution-collapse breccia pipes. Accompanying plate and figures show these permissive areas.

\section{INTRODUCTION}

Platinum-group elements (PGE) are found within many geologic environments, most of which are present within the conterminous U.S. Zientek and others (1988) made a preliminary assessment of PGE in the U.S. This report provides a more comprehensive overview of PGE in sedimentary environments within the conterminous U.S. by presenting mineral deposit models that emphasize PGE and by discussing specific formations or regions of the country permissive for the various types of deposits in which PGE may be found. Throughout this report these permissive formations or regions will be referred to as "tracts." I present information on PGE analyses for specific deposits or areas when such data are available. Many of the tracts shown on plate 1 and figures 1 and 2 are also permissive for other commodities, but because this report emphasizes PGE, information pertaining to other commodities is incidental and not meant to be comprehensive.

PGE are generally thought of as being associated with mafic and ultramafic rocks rather than with sedimentary rocks; however, an important source of PGE has been placer deposits, such as those in the Ural Mountains, Russia (Mertie, 1969). Placers are a rather specialized case because the PGE in many placer deposits were derived from terranes where there are large exposures of mafic and ultramafic rocks shedding PGE into stream drainages. Placer deposits are discussed first because they provide a logical transition from mafic and ultramafic environments into sedimentary environments. In addition to placer deposits, there are other sedimentary environments where geochemical, mineralogical, and mineraldeposit data indicate that PGE are or may be present. PGE are well documented in the Kupferschiefer sediment-hosted copper deposits of northern Europe (Kucha, 1982, 1983). Closely allied with sediment-hosted copper deposits in terms of mechanisms of formation (that is, deposition of metals at 
a reducing horizon) are metalliferous black shales and unconformity uranium-gold deposits, both of which contain PGE (see references in appropriate sections below). Quartz-pebble conglomerates in the Witwatersrand of South Africa have yielded PGE as byproducts from several gold deposits (Pretorius, 1981). Because it has been long known that small amounts of PGE are present in some coals, one section of the report discusses the favorability of coal basins for containing PGE deposits. Several sedimentary environments have either not been analyzed or have not yet been found to contain significant concentrations of PGE, but various characteristics of the environments indicate that they are permissive for the occurrence of PGE. These environments contain Blackbird cobalt-copper deposits, southeast Missouri leadzinc deposits, and solution-collapse breccia pipe uranium deposits. The inclusion of Blackbird cobalt-copper deposits within a sedimentary environment poses some problems. The deposits are hosted by rocks having a very large mafic volcanic component (Nash and Hahn, 1989). However, because the overall environment is sedimentary (including turbidites) and because the deposits are stratabound, the Blackbird deposits are included in this discussion.

\section{ACKNOWLEDGMENTS}

Discussions during the preliminary phase of this assessment with A.K. Armstrong, R.I. Grauch, T.S. Hayes, A.V. Heyl, B.R. Lipin, J.T. Nash, K.J. Schultz, J.F. Slack, E.W. Tooker, and others, whom I may have inadvertently omitted, provided a starting point for some of the material contained in this report. I thank K.J. Wenrich, G.A. Desborough, Jim Tucker, H.L.O. Huyck, and R.B. Schultz for providing samples for PGE analysis of solution-collapse breccia pipes, black shales, the Monterey Formation, strata near the Creta deposit, and black shales of Kansas, respectively, and to M.P. Foose for sharing PGE data for samples collected at the Blackbird Mine. Special thanks go to Jeff Mauk for giving me a tour of the White Pine Mine in 1989 and for allowing collection of samples of the Nonesuch Shale for PGE analysis.

\section{DEPOSIT MODELS}

Some of the deposit models presented below roughly follow the presentations of Cox and Singer (1986) in format and content. Others provide information about PGE only or rationale for inclusion in this compilation, if PGE data are lacking. They are presented in approximate order of decreasing knowledge of PGE for each deposit type. This does not necessarily correlate with what might be the order of importance of the deposit types relative to the possible discovery of economic quantities of PGE in the U.S.

\section{PLACER DEPOSITS}

This model expands upon those for placer gold-PGE (Yeend, 1986) and placer PGE-gold (Yeend and Page, 1986) deposits of Cenozoic age. These two types of placers differ primarily in grade and tonnage characteristics, a reflection of source terranes rather than a function of mechanisms of concentration.

Descriptive Summary: PGE and gold minerals are present in flakes, grains, and rarely nuggets in gravel- to clay-sized fractions of alluvial, beach, eolian, and glacial deposits and lithified equivalents.

General References: Yeend (1986); Yeend and Page (1986); Boyle (1979); Mertie (1969).

\section{REGIONAL SETTING}

Tectonic Setting: Placers commonly form in shield areas that have produced multicycle sediments, areas of accreted terranes and convergent plate margins, areas containing high-level terrace gravels, and conglomerate near major fault zones.

Regional Lithologic Characteristics: To generate placer deposits of any kind, suitable source rocks must be exposed in the drainage basins. For accumulation of PGE in alluvial placer deposits, mafic and ultramafic rocks exposed within the basins, such as Alaskan-type ultramafic complexes, suggest a greater likelihood that PGE might accumulate in placers; however, because PGE can be derived from other sources, a lack of these rocks does not necessarily preclude the presence of PGE in placers.

Age: Most placer deposits are Quaternary; some are Tertiary. Older deposits, especially those from more rugged terranes, are not commonly preserved. An exception to this is the quartz-pebble conglomerates of Proterozoic age that are host to gold-uranium deposits (see model below).

\section{LOCAL SETTING OF ORE DEPOSITS}

Rock Types: Unconsolidated gravel and conglomerate of fluvial, glaciofluvial, and beach origin, particularly, but not limited to, those containing heavy minerals indicative of ultramafic source terranes (PGE) and low-grade metamorphic source terranes (gold), are the main hosts of placer deposits. Sand or sandstone are less important. If bedrock is highly fractured or shattered, placer material may be present in the upper meter or so.

Depositional Environment: Placers are deposited in streams where gradients flatten and velocities lessen, in 
beaches where winnowing of the surf causes heavy minerals to concentrate, in eolian environments, and as residual products of in situ weathering.

\section{DESCRIPTION OF DEPOSITS}

Size and Shape: Placers vary in size from small uneconomic accumulations a few centimeters thick to deposits tens of meters thick and tens of kilometers long yielding several million tonnes of ore, as in large PGE placers in Russia. Deposits may be tens of meters to nearly $5 \mathrm{~km}$ wide. Placers commonly accumulate near the bedrock or directly above a finer grained or more compacted layer, thus causing many deposits to have a tabular form, but other ore configurations such as small pockets are also found.

Mineralogy: Source terrane plays a significant role in determining what minerals may accumulate in placer deposits. Common heavy minerals found in placer accumulations include gold and gold-silver alloys, PGE and platinum-iron alloys, magnetite, ilmenite, hematite, zircon, chromite, pyrite, garnet, rutile, corundum, monazite, cassiterite, wolframite, scheelite, cinnabar, and sulfide minerals. Less commonly, other minerals including several gemstones may accumulate in placers. High (and low) specific gravity minerals that accumulate in placers have these features in common: (1) physical resistance to abrasion and comminution, (2) chemical resistance to solution in surficial waters, and (3) general equidimensional shape (Boyle, 1979). The dominant PGE mineral is platinum-iron alloy with inclusions of osmium-iridium alloys. Numerous minor and rare minerals may be present, generally as inclusions or intergrowths with the platinum-iron alloys. PGE minerals in some placers are included in other detrital grains such as magnetite or chromite. Cabri and Harris (1975) determined that PGE in placers derived from alpine deposits are dominated by osmium-iridium alloys and low $\mathrm{Pt} /(\mathrm{Pt}+\mathrm{Os}+\mathrm{Ir})$ ratios whereas placers derived fromAlaskan-type zoned intrusions (see Page and Gray, 1986) have high $\mathrm{Pt} /(\mathrm{Pt}+\mathrm{Os}+\mathrm{Ir})$ ratios.

Ore Controls: Source rock is the most important control of the minerals that accumulate in any given placer. Weathering can also be important; for example, gold may be dissolved and reprecipitated on gold nuclei in residuum or alluvium. In streams with favorable source terranes, trapping mechanisms are required to concentrate the heavy minerals. These include clayey or other less permeable beds which prevent the particles from migrating downward, riffles in the streambed, fractured bedrock transverse to stream flow, or other structures such as bedding or schistosity perpendicular to stream flow.

Ore Texture and Size: PGE and gold particles are generally flakes or flattened particles with rounded edges; they are rarely equidimensional nuggets. Grains are typi- cally small-clay to sand sized, usually less (to far less) than $1 \mathrm{~mm}$. Generally, the farther detrital minerals have traveled from their source the smaller and more rounded they become (Boyle, 1979; Raicevic and Cabri, 1976). PGE nuggets are rare and generally are found close to their source rocks. The largest nugget, found in the Ural Mountains, Russia, reportedly weighed more than $11 \mathrm{~kg}$ (Mertie, 1969).

Geochemical Indicators: The best indicator of placer deposits are the minerals themselves. Stream sediments from placers may contain anomalous $\mathrm{Ag}, \mathrm{As}, \mathrm{Hg}, \mathrm{Sb}, \mathrm{Cu}$, $\mathrm{Fe}, \mathrm{S}$, or $\mathrm{Cr}$.

\section{ECONOMIC CONSIDERATIONS}

Grade and Tonnage Models: Grade-tonnage models are found in Orris and Bliss (1986) and Singer and Page (1986) for placer gold-PGE and placer PGE-gold, respectively. Subsequently, Bliss and others (1987) showed that gold grade and placer volume, in some cases, depend more on mining method than on traditional placer classifications. They presented revised grade-tonnage models for gold constructed on the basis of mining method. Gold-PGE deposits tend to be larger (about 0.002 to 200 million $t$ ) than PGEgold deposits (about 0.0016 to about 7 million $t$ ). The PGEgold placer grade-tonnage models were constructed using placer data from the Ural Mountains, Russia, where the placers are particularly large; thus, the grade-tonnage models may be inappropriate for application to the U.S. Gold grades are typically less in PGE-gold placers than in goldPGE placers, but high gold grades in PGE-gold deposits overlap with low gold grades in gold-PGE deposits (see below). Platinum grades are not given for gold-PGE placers; in PGE-gold placers they range from about 0.07 to $15 \mathrm{ppm}$. Gold is present in about 30 percent of the PGE-gold deposits and osmium, iridium, and palladium are found in about 10-20 percent of deposits in concentrations ranging from about $1.5 \mathrm{ppb}$ (the low for Pd) to about $500 \mathrm{ppb}$ (the high for Os). The individual large alluvial-fan gold placers of the Sierra Nevada have produced from 15.6 to about 208.4 $\mathrm{kg}$ PGE at grades ranging from 0.32 to $59 \mathrm{ppb}$ PGE (data from Mineral Resources Data System). Recorded production from other conterminous U.S. placers has been minor.

Other Distinctions Between gold-PGE and PGE-gold Placers: In PGE-gold placers, the gold may be incidental. The PGE lodes from which they are derived have essentially no gold, and the Au:PGE ratio increases away from the PGE lode source suggesting dilution by gold supplied from other sources and dropping out of PGE close to sources. In contrast to gold-PGE deposits, in which $A u: P G E=500: 1$ to 1,000:1, PGE-gold placers have very low Au:PGE ratios $(0: 1$ to $50: 1)$. Sources of PGE in some gold-PGE placers may include unconventional deposit types such as low-sulfide gold-quartz veins. 
Exploration Guides: Presence of other placer material, particularly gold, and suitable source terrane for PGE are the primary exploration guides. Other geochemical indications are probably less useful than finding the placer materials themselves.

Possible Associated Deposits: Various PGE lode deposits, particularly those in zoned Alaskan-type plutons, upstream from placer accumulations may be spatially associated with PGE-bearing placers (Ural Mountains, Russia), although in the U.S., many of the associated lode deposits, if they remain, have eluded discovery.

\section{SEDIMENT-HOSTED (REDBED) COPPER DEPOSITS}

This model expands upon that of Cox (1986b).

Descriptive Summary: Deposits are characterized by disseminated, stratabound copper-sulfide minerals, with or without lesser concentrations of other metals, in reduced rocks overlying a redbed sequence. The reduced rocks represent a major marine transgression in an area of intracontinental rifting or in a basin undergoing rapid subsidence.

General References: Cox (1986b); Gustafson and Williams, (1981); Hayes (1985); Boyle and others (1989) including a summary paper by Kirkham; Kucha $(1982,1983)$.

\section{REGIONAL SETTING}

Tectonic Setting: Deposits formed in depressions thought to be associated with failed continental rifts and passively but rapidly subsiding basins (Borg and others, 1988; Gustafson and Williams, 1981). Examples of the former include Kupferschiefer and Zaire-Zambian Copperbelt and of the latter, Creta, Oklahoma, where a rift association is less obvious. In a very general sense, deposits associated with rift valleys seem to have more extensive and more complex mineralization than do those in passively subsiding basins.

Basin Characteristics: Basins are typically deep (greater than 1,000 m) and cover hundreds of square kilometers (Jowett and others, 1987; Borg and others, 1988). However, a large proportion of the rocks within the basins formed from shallow-water deposits derived from deltaic and other near-shore sediments (Hayes and Einaudi, 1986; LaPoint, 1979; Johnson, 1976) that were shed into a subsiding basin. The basin is typically filled with a sequence of bimodal (Gregor Borg, unpub. data; Hayes, 1985) or predominantly basaltic (Gustafson and Williams, 1981; Kirkham, 1989) volcanic rocks and sedimentary rocks characterized by a prominent continental redbed sequence overlain by rocks representing a major marine transgression (Gustafson and Williams, 1981; Hayes, 1985). Individual basins differ, but volcanic rocks are more common in rifted basins and are generally most abundant near the basin floor, below and interbedded with the redbeds. Rocks of the marine transgression commonly contain thin organic-carbon-rich reduced shales or sandstones that host ores bodies; carbonate assemblages may also be present and, in some deposits, host the ores (Hayes, 1985). Commonly, evaporite deposits are present in the middle of the basins (Copperbelt deposits, Kupferschiefer, midcontinental U.S.).

Basement Rocks: Surrounding the basins is continental crust commonly composed of granitoids and metamorphosed rocks.

Age: Ages range from Proterozoic to Holocene, although Proterozoic and Carboniferous to Permian deposits are most common (Kirkham, 1989).

Metamorphism: Regional greenschist-facies metamorphism is characteristic of several of the basins (for example, metasedimentary rocks of the Belt Supergroup (Hayes and Einaudi, 1986)), whereas rocks in other basins (midcontinental U.S.) are not metamorphosed. The metamorphism, although post mineralization, may have, in some cases, remobilized and concentrated metals into deposits that may not otherwise have been economic (J.M. Whipple, written commun., 1991). Metamorphism resulted primarily in in situ recrystallization of sulfide minerals and conversion of primary gangue minerals to new minerals, which makes identification of primary mineral zonation more difficult.

\section{LOCAL SETTING OF ORE DEPOSITS}

Stratigraphic and Lithologic Setting: The common feature to most deposits is that ores have been deposited in rocks of the first major marine transgression over continentally derived redbeds. Hayes (1985) indicated three major local sedimentary environments that host these copper deposits: carbonaceous algal dolomite (White Pine, Michigan), sandstone (Spar Lake, Montana), and shale (Creta, Oklahoma). The ores typically, but not always, are found in reduced rocks stratigraphically above the redbed sequences, where organic compounds or reduced mineral assemblages are present or thought to have been present.

Basinal Setting: Most deposits are located near basin margins or basement highs rather than in the centers of the basins (Borg and others, 1988; Jowett and others, 1987).

\section{DESCRIPTION OF COPPER DEPOSITS}

Size and Shape: Most of these deposits are laterally extensive and may cover many square kilometers, but they are also usually very thin, commonly only centimeters thick. Those in sandstones are tongue shaped. This deposit morphology corresponds with the commonly thin beds of many of the host rocks and, in some cases, the ore minerals are found only in specific horizons of the host rocks (for exam- 
ple, PGE in the Kupferschiefer lie within a few centimeters of the bottom of the host black shale (Kucha, 1982)).

Mineralogy and Zoning: Chalcocite is the dominant economic sulfide in most deposits, although in some of the Zambian and Zaire deposits chalcopyrite or bornite are important and minor amounts of covellite, digenite, native copper, and cuprite are present (Hayes, 1985; Sweeney and others, 1986; Bartholomé and others, 1973). Uranium and cobalt minerals (carrollite) are present in economic amounts in some deposits (particularly in the Zaire-Zambian Copperbelt). Galena, sphalerite, PGE minerals (see below), and metal-rich organic compounds are associated with some deposits (Kucha, 1982; Hayes, 1985; Gustafson and Williams, 1981). A distinct mineralogic zoning has been noted at many deposits, the notable exceptions being those deposits in the midcontinent U.S. and some in New Mexico, where zoning is not as pronounced (Gustafson and Williams, 1981; Hayes, 1985). Zoning typically cuts across bedding at low angles. Toward the center of deposits from laterally outside and generally also from above, the zones are as follows (see Hayes, 1985; Hayes and others, 1989): pyrite, leucoxene; trace galena, trace sphalerite, chalcopyrite, pyrite, leucoxene; chalcopyrite, trace pyrite, possible carrollite, leucoxene; bornite, digenite, hematite; digenite, chalcocite, hematite. In deposits where distinctive zoning is lacking (for example, Creta), chalcocite disappears into weakly pyritic fringes as carbon-rich facies pinch out. Zoning covers kilometers laterally and meters or less vertically. The characteristic zones of these deposits suggest a paragenetic sequence resulting from a single influx of ore fluids into reactive host rocks in which pyrite is replaced by galena and sphalerite; pyrite is replaced by chalcopyrite and carrollite; and remnant pyrite and chalcopyrite are replaced by bornite, digenite, and chalcocite (see Hayes, 1985). This sequence suggests continuous addition of copper-rich solutions from sources nearer the chalcocite-rich base of the zoned assemblage.

Form of Mineralization: Ore minerals ordinarily are disseminated. In some deposits they replace organic matter or pyrite (Gustafson and Williams, 1981), whereas in other deposits, like Spar Lake (Hayes and Einaudi, 1986), the ore minerals occupy former pore spaces between detrital grains. Locally, small veinlets are present, and, in the case of deposits in the Lisbon Valley area, Utah, redbed-derived fluids deposited vein material along faults when reduced aquifers higher in the stratigraphic section were encountered (Morrison and Parry, 1986).

Alteration: Diagenetically related changes in mineralogy and chemistry have accompanied ore formation. Such changes are best described for Spar Lake, which has several zones associated with the sulfide mineralization (see above); similar diagenetic changes can be expected in other deposits. Development of diagenetic-related gangue minerals from top (outside) to bottom (center) include calcite, chlorite, and ankerite (Hayes and Einaudi, 1986). The paragenetic sequence of cementing materials consists of (1) rims of oxides, clays, or pyrite developed around detrital grains, (2) overgrowth of potassium-feldspar and quartz, and (3) pore-space filling by carbonate and sulfide minerals (Hayes and Einaudi, 1986).

Structures: Some ores are associated with minor faulting that was contemporaneous with diagenesis, but most ores are not generally associated with major structures except in the case of Lisbon Valley, where major faults allowed the ore fluids to migrate upward into reduced rock above the redbed source of the ore fluids (Morrison and Parry, 1986). The most important, albeit indirect, structural control is the location of basement highs and lithologic control of more permeable versus less permeable beds.

Post Depositional Changes: Some deposits have undergone regional metamorphism. Weathering of the copper-sulfide minerals primarily forms azurite and malachite, but in the Copperbelt of Zambia and Zaire, copper-phosphate and -silicate minerals also formed (Clemmy, 1974; Annels and others, 1983).

\section{ORE GENESIS}

Timing: Theories range from syngenetic to epigenetic; however, the most recent view is that these deposits form during late diagenesis along with cementation and lithification (see Jowett and others, 1987, for discussion of the Kupferschiefer; also see Hayes, 1985; Hoeve and Quirt, 1989) and are termed syndiagenetic.

Ore Fluid Characteristics: Characteristics of ore fluids are poorly known. Temperatures were probably quite low (less than $75^{\circ} \mathrm{C}$ to a maximum of possibly $250^{\circ} \mathrm{C}$ but almost always less than $150^{\circ} \mathrm{C}$ ) (see Hayes, 1985; Gustafson and Williams, 1981; Rose, 1989; Bartholomé and others, 1973). $\mathrm{pH}$ was acid to neutral. Intermediate $\mathrm{f}_{2}$ is expected. No quantitative fluid-inclusion data are available, but ore solutions must have been very saline, as dilute low-temperature fluids cannot transport large quantities of copper. Several chloride-bearing crystals (containing magnesium, calcium, sodium, and potassium) have been identified in fluid inclusions at the Shinkolobwe deposit (De Magnée and Francois, 1988). This suggests a possible connection to marine evaporite brines.

Mechanisms of Ore Deposition: Ores are deposited at a redox boundary usually immediately above the redbed sequence (Jowett and others, 1987; Hayes, 1985; Gustafson and Williams, 1981). Sulfur isotope studies indicate that sulfate-reducing bacteria were associated with the redox reactions, even where organic matter is no longer present in the host rocks. There have been several models proposed for the generation and migration of fluids. The two most often called upon mechanisms are: (1) convection cells that form during late diagenesis, when waters move up from the middle, deeper, parts of the basin and are then recycled back into the basins (Borg and others, 1988) and (2) sabkha processes 
in which, again, fluids move up from the deeper parts of the basins but are evaporated rather than recycled (for example in Zambia (Annels, 1974)). In both cases, however, when the fluids pass into the more reduced rocks, the sulfide minerals are deposited.

Sources of the Metals: There are three possible sources for the metals (see Hayes, 1985; Gustafson and Williams, 1981): (1) the underlying mafic volcanic rocks within the basin, which should have relatively high concentrations of the copper and cobalt that could be leached by migrating fluids (see Annels, 1974); (2) the sediments themselves, from which metals could be leached as the fluids migrate through them; and (3) rocks outside the basin, which could be leached of metals as waters move through them into the basins.

\section{ECONOMIC CONSIDERATIONS}

Grade and Tonnage Models: See Mosier and others (1986) for copper, silver, and cobalt grade and tonnage models. Median tonnage is 22 million $t$ and median grade is 2.1 percent $\mathrm{Cu}$. Ranges of averages for the deposits used to construct the model are 0.2 to 1,600 million $t$ and 0.7 to 10 percent $\mathrm{Cu}$. Average silver and average cobalt are economic as byproducts in about 2 percent of deposits. Average silver grades are 1 to $200 \mathrm{ppm}$ and average cobalt grades are 0.16 to $0.5 \mathrm{ppm}$. PGE, uranium, and gold are byproducts of production in some Kupferschiefer and Zambian deposits (N.J Page, oral and written commun., 1988, 1989).

Geochemical Signatures: Copper is the best geochemical indicator for these deposits. Some deposits have associated silver, lead, zinc, or cobalt anomalies and some are weakly radioactive.

Exploration Guides: Geochemistry and location near basin margins or basement highs in reduced sedimentary rocks above redbed sequences are best guides to deposits.

Possible Associated Deposits: There may be spatially associated evaporites and basaltic copper deposits and possibly a distal association with sandstone-hosted uranium and lead and perhaps Mississippi Valley or carbonatehosted lead-zinc deposits (Kirkham, 1989). A genetic association of these deposits is not necessarily implied.

\section{PGE MINERALIZATION}

Much of the following information has come from Kucha (1982, 1983), who has studied the PGE occurrences in the Kupferschiefer. PGE information for other regions is limited, although PGE are known to be present and even produced as a byproduct in some Copperbelt (Zambian and Zaire) deposits, as at Musonoi.

Host Rocks and Lithologic Controls: PGE are found in reduced layers above redbeds but more laterally and stratigraphically restricted than copper mineralization. PGE generally are found with digenite and covellite rather than with chalcocite. They are in the same zone as copper mineralization in zoned deposits. In the Kupferschiefer, PGE are within a few centimeters of the bottom of the host shale. Factors such as clay mineralogy and organic chemistry may be important for localizing PGE.

Mineralogy: PGE are present in many different compounds such as organic matter, base-metal sulfide structures, selenides and arsenides, and PGE minerals. Some of the documented occurrences in the Kupferschiefer include platinum-rich kerogen (an organic compound), alloys of PGE, alloys with gold, native palladium, admixtures in mooihoekite and haycockite, sobolevskite, palladium arsenides, nickel and cobalt arsenides, disseminated in unnamed copper-iron-silver sulfide compounds, and a variety of PGE-bearing arsenides and sulfarsenides that have no formal mineral names. At the Musonoi deposit in Zaire, two palladium-bearing selenide minerals have been identified, oosterboschite $\left((\mathrm{Pd}, \mathrm{Cu})_{7} \mathrm{Se}_{5}\right)$ and cuproan palladian trogtalite $\left(\left(\mathrm{Co}_{0.64} \mathrm{Cu}_{0.31} \mathrm{Pd}_{0.10}\right)_{\Sigma=1.05} \mathrm{Se}_{1.95}\right)(\mathrm{Cabri}, 1981$; Cabri and Laflamme, 1981).

Associated Metals: $\mathrm{Au}, \mathrm{Ag}, \mathrm{Hg}$, and $\mathrm{Bi}$; also $\mathrm{Pb}, \mathrm{Se}$, and numerous transition metals may accompany the PGE.

Geochemical Aspects of PGE Deposition: This discussion is based on Kupferschiefer. There seems to be a positive correlation of precious metals with phosphate content, with clay-rich shale in which illite is the main clay, and with bituminous shale. The concentration of metals (including PGE) at the base of the black shale suggests that the metals acted as catalysts of oxidation and desulfurization of the organic material. Kucha $(1982,1983)$ has suggested that gamma radiation from uranium-bearing organic material may have been important in stimulating chemical reactions that resulted in concentration of PGE and gold.

PGE Concentrations: Concentrations vary depending on specific host rock. Kucha $(1982,1983)$ analyzed several types of rock and organic compounds from the Kupferschiefer. His data are presented below.

\begin{tabular}{lll}
\hline Element & Concentration & \multicolumn{1}{c}{ Medium analyzed } \\
\hline $\mathrm{Pt}+\mathrm{Pd}$ & $1 \mathrm{ppm}$ (max.) & Base of black shale \\
$\mathrm{Pt}+\mathrm{Pd}$ & $10-20 \mathrm{ppm}$ & Dilution of pitchy shale in $\mathrm{HCl}$ and $\mathrm{HF}$ \\
$\mathrm{Pt}$ & $700 \mathrm{ppm}$ & Kerogen (an organic compound) \\
$\mathrm{Pd}$ & $400 \mathrm{ppm}$ & \\
$\mathrm{Pt}$ & $30 \mathrm{ppm}$ & Phosphatic shale \\
$\mathrm{Pd}$ & $30 \mathrm{ppm}$ & \\
$\mathrm{Pt}$ & $30 \mathrm{ppm}$ & Limestone \\
$\mathrm{Pd}$ & $60 \mathrm{ppm}$ & Pb-Ag-Hg-Cu-rich shale \\
$\mathrm{Pd}$ & $20 \mathrm{ppm}$ & Precious-metal-bearing shale \\
$\mathrm{Pt}$ & $10-370 \mathrm{ppm}$ & \\
$\mathrm{Pd}$ & $10-120 \mathrm{ppm}$ & \\
\hline
\end{tabular}

Kucha $(1982,1983)$ also mentioned the presence of iridium but did not give concentrations. The Musonoi deposit in 
Zaire contains $6 \mathrm{ppm} \mathrm{Pd}$ and $750 \mathrm{ppb} \mathrm{Pt}$ in ore-grade rocks (N.J Page, written commun., 1988). Analyses of eight samples collected from Zambian deposits show a maximum of $18 \mathrm{ppb} \mathrm{Pt}$ and $38 \mathrm{ppb} \mathrm{Pd}$.

\section{METALLIFEROUS BLACK SHALES}

Descriptive Summary: Black shales are fissile, exceptionally rich in organic material and iron-sulfide minerals, and only rarely contain fossils (Pettijohn, 1975). They generally form layers millimeters to tens of meters thick within thicker sedimentary sequences and typically have a high organic-carbon content. The elements that are anomalously concentrated in many black shales include $\mathrm{Ag}, \mathrm{Mo}, \mathrm{Zn}, \mathrm{Ni}$, $\mathrm{Cu}, \mathrm{Cr}, \mathrm{V}$, and more. Recent analytical work has shown that PGE are present in some mineralized shales.

General References: Huyck (1990); Pettijohn (1975); Vine and Tourtelot (1970).

Definitions: Black shales are typically dark-colored (though not necessarily black), fine-grained, laminated sedimentary rocks that are typically argillaceous and contain greater than 0.5 wt percent carbon (Huyck, 1990). Some contain particularly carbon-rich or phosphatic layers that may be only millimeters thick. Thin laminations are common, whereas evidence of bioturbation is rare. Most fossil fauna present were derived by settling. Metalliferous black shales are those that are enriched in a given metal by a factor of $2 \times$ (with some exceptions) relative to the U.S. Geological Survey standard SDO-1 (Huyck, 1990). Metalliferous black shales, as used in this report, exclude those that host sediment-hosted copper deposits associated with redbed sequences, although they fit Huyck's definition.

Composition: As much as 15 percent organic carbon can be present as solid carbon compounds, spores, plant fragments, or waxy-bituminous or oily material. The claysized fraction consists largely of illite or sericite, authigenic feldspar, quartz, and carbonate minerals. Pyrite or marcasite usually is present, commonly to several percent (Bell, 1978). Micas, apatite, and barite are also common in black shales (Vine and Tourtelot, 1970).

Sources of Mineral Constituents: Minerals may be detrital (quartz, feldspar, micas, clay), precipitated in situ (calcite, dolomite, biogenic silica, apatite), authigenic or diagenetic (clay minerals, feldspar, barite, pyrite), or weathering products (iron oxides, sulfates, carbonates) (Vine and Tourtelot, 1970).

\section{REGIONAL SETTING}

Depositional Environment: Black shales were deposited under anaerobic conditions. In what environment these conditions were achieved is less certain. It appears that black shales can form in virtually any sedimentary environment except desert-eolian. They are associated with restricted marine, or less commonly lacustrine, basins in which there is a sharp salinity increase with depth or they are found along continental margins where high biological productivity and organic decay reduce the bottom to an anoxic state (Bell, 1978). Such environments include areas of low-energy transgressions, intersection of oxygenminimum zones with the sedimentary surface, areas of upwelling, silled basins, coastal swamps, and alluvial plains (Meissner and others, 1984). Requirements for oilshale (organic-carbon-rich shale) deposition include a high-energy oxygenated environment that encouraged high organic productivity, a low-energy anoxic environment in which the organic matter was preserved, and a lack of dilution by other constituents (Meissner and others, 1984). Preservation is accomplished by separating the site of organic productivity from that of deposition through mechanisms such as stratified layers of water.

Basin Characteristics: Basins are generally less than $1,500 \mathrm{~m}$ deep and commonly contain cool to cold water (Bell, 1978). Sediment input to the basins is very low either because of a low sedimentation rate or because the sediment is trapped before it reaches the basins, but the input of organic matter into these basins is high. The water mass is poorly circulated because of factors such as a sharp salinity increase with depth or low tides. The bottoms of the basins are generally smooth and featureless, which reduces turbulence generated by storms and tides.

Age: Black shales may be any age. Though uncommon, Archean black shales are known (Ripley and Nicol, 1981; Strauss, 1986). There is a preponderance of Paleozoic black shales in the eastern U.S.

\section{METAL ENRICHMENT}

Several definitions have been proposed for metalliferous black shales, none of which are completely satisfactory for various reasons (see discussion in Huyck, 1990). The definition provided above (from Huyck, 1990) allows comparison of black shales with a well-characterized standard for easy determination of whether the black shale in question is metalliferous. Metal enrichment can occur in black shales deposited in any environment. In their study of metalliferous black shales, Vine and Tourtelot (1970) provided insights into the characteristics of and mechanisms of enrichment to produce metalliferous black shales. The following discussion is based on their work.

Metals in Shale Components: Certain elements tend to be associated with various components of the shale. $\mathrm{Al}$, $\mathrm{Ti}, \mathrm{Ga}, \mathrm{Zr}, \mathrm{Sc}$, and, in some cases, $\mathrm{Be}, \mathrm{B}, \mathrm{Ba}, \mathrm{Na}, \mathrm{K}, \mathrm{Mg}$, and $\mathrm{Fe}$ are found with detrital minerals. $\mathrm{Ca}, \mathrm{Mg}, \mathrm{Mn}$, and $\mathrm{Sr}$ are enriched in the carbonate fraction. The organic-carbon fraction locally can contain $\mathrm{Ag}, \mathrm{Mo}, \mathrm{Zn}, \mathrm{Ni}, \mathrm{Cu}, \mathrm{Cr}$, and $\mathrm{V}$, and less commonly $\mathrm{Co}, \mathrm{Pb}, \mathrm{La}, \mathrm{Y}, \mathrm{Se}, \mathrm{U}$, and $\mathrm{Tl}$. This is also the likely locus of PGE enrichment, which is discussed in more detail below. 
Comparison to Unenriched Shales: Often, the only way to distinguish an enriched from an unenriched shale is through chemical analyses, as they are otherwise indistinguishable.

Variables That May Affect Metal Content: Sea-water composition, metal content of the rocks supplying detrital material, sedimentary facies and depositional environment, the types of organic matter and organisms present, and paleotectonic setting all influence metal content. These factors, together, help determine whether metals are being supplied to the system and, if present, whether conditions are favorable for their extraction and concentration. Unfortunately, these factors are nearly impossible to measure.

Mechanisms of Enrichment: Metals may be derived syngenetically by (1) extraction from seawater by organisms, (2) metabolism of organisms, (3) adsorption onto decaying organisms, and (4) decaying organisms supplying a sulfur source for sulfide precipitation. All syngenetic mechanisms have problems generating the quantity and variety of metals present in many shales. Metals may also be introduced during diagenesis (see sediment-hosted copper model) or later epigenetically; as waters pass through the rocks, metals are deposited in the reducing environment of the shale. It is usually difficult to distinguish diagenetic from epigenetic enrichment because the only significant difference is the derivation of the fluids from either inside or outside of the sedimentary system, respectively.

Uraniferous Black Shale: (See Bell, 1978; McKelvey, 1955; Nininger, 1954; Durham, 1987.) These are a special subset of metalliferous black shales. They form large-volume low-grade uranium deposits, which are currently uneconomic. Uranium is typically most concentrated in carbonaceous shales containing abundant plant material, sulfide minerals (pyrite or marcasite), and less commonly phosphate minerals, and no, or very little, calcium carbonate. Nearly all uraniferous shales are Paleozoic or older, a noted exception being the Miocene Monterey Formation of California (Durham, 1987). Uranium is finely disseminated in the organic-carbon-rich or clay fraction and may be present as organic complexes and is thought to be syngenetic. There seems to be an inverse relation between petroleum and uranium in black shales although small amounts of petroleum are present in all uranium-bearing black shales (Nininger, 1954).

Examples: Mecca Quarry Shale Member of the Linton Formation, Indiana (Rainer and Richardson, 1963); Phosphoria Formation, western U.S. There are many, many other black shales.

\section{PGE}

There are few PGE studies of black shales. Recently, however, Grauch and others (1991) reported the presence of PGE in black shales in China and Canada. Lower Cambrian black shales in China host molybdenum- and nickel- rich deposits that contain an average (for seven samples) of $570 \mathrm{ppb} \mathrm{Pt}, 660 \mathrm{ppb} \mathrm{Pd}$, and $550 \mathrm{ppb} \mathrm{Au}$ in a single layer generally between 2 and $15 \mathrm{~cm}$ thick (R.I. Grauch, written commun., 1991). Although only the deposits near Songlin, Zunyi County, Guizhow Province are being mined presently, the mineralized area extends discontinuously for $1,600 \mathrm{~km}$ (Coveny and Chen, 1990). Thus far, PGE have not been recovered from these deposits but stockpiles may be mined for them in the future (Coveny and Chen, 1990). In the Yukon Territory of Canada, Devonian nickel-rich sulfide layers lithologically similar to, but less complex than, those in China contain an average (for three samples) of $430 \mathrm{ppb}$ Pt and $230 \mathrm{ppb}$ Pd (R.I. Grauch, written commun., 1991). Analyses of eight representative black shale samples from the western U.S. ranging in age from Middle Proterozoic to Permian yielded a maximum value of 17 ppb Pt, 19 ppb Pd, and 1 ppb Ru (G.A. Desborough through M.L. Zientek, written commun., 1989). PGE were not detected in six core samples from the Monterey Formation (J.A. Peterson, unpub. data, 1990). In a retrieval of PGE analyses from the PLUTO geochemical data base of the U.S. Geological Survey, five samples of the Meade Peak Phosphatic Shale Member of the Phosphoria Formation are reported to contain 1.6 to $2.0 \mathrm{ppm} \mathrm{Pd;} \mathrm{the} \mathrm{accu-}$ racy of this information has not been verified. Orth and others (1988) reported PGE anomalies in a 3-m section of Lower Mississippian black shale in Oklahoma. Their maximum values for PGE are $0.56 \mathrm{ppb}$ Ir, $150 \mathrm{ppb} \mathrm{Pt}$, and 7.5 $\mathrm{ppb}$ Os. They attributed the anomalies to precipitation from sea water, bacterial enrichment, and detritus derived from ultramafic sources, depending on the host rock analyzed.

Analogy of metalliferous black shales, as used in this report, to some sediment-hosted copper environments (Kucha, 1982, 1983) and inferences made from geochemical suites that are associated with black shales (Vine and Tourtelot, 1970) further suggest that PGE should be present in this environment. If Kupferschiefer is a valid analogy, concentrations of PGE might be in the tens of parts per million in the highly enriched areas, which are likely to be the very organic-carbon-rich parts of the shales where PGE may be contained in organic compounds as well as minerals. Palladium and iridium contents of some deep-sea sediments of silt and clay size average 3.7 and $0.35 \mathrm{ppb}$, respectively, and the data suggest that the palladium content of sediments of terrestrial origin is similar to or slightly enriched over that of the source region (Crocket and others, 1973). If this is also true for black shales, concentrations of PGE in the low parts per billion range might also be expected in most shales.

\section{UNCONFORMITY URANIUM-GOLD DEPOSITS}

Uranium mineralization in unconformity-type deposits consists of fracture and breccia filling in metapelites, 
metapsamites, and quartz arenites below, above, or across an unconformity between Early and Middle Proterozoic rocks (Grauch and Mosier, 1986). Nutt and others (1986) suggested that structural controls may, in some cases, be more important than the unconformity itself in localizing these deposits. Recently, a model has been proposed for these deposits in which the mineral deposits formed at a redox boundary below redbed sequences during "intense" diagenesis (Hoeve and Quirt, 1989), making them somewhat similar to sediment-hosted copper deposits except that the reducing environment lies below rather than above the redbeds.

Occurrences of PGE in unconformity uranium-gold deposits have been reported at Cluff Lake and in the Beaverlodge area, Athabasca basin, Saskatchewan, Canada, and at Coronation Hill and Jabiluka in Australia. In the D Zone at Cluff Lake, uranium is associated with $\mathrm{Co}, \mathrm{Ni}$, $\mathrm{Cu}, \mathrm{Pb}, \mathrm{S}, \mathrm{Se}, \mathrm{Te}, \mathrm{As}, \mathrm{Bi}, \mathrm{Au}$, and PGE (Hoeve and Sibbald, 1978). The mineralized rocks contain uraninite; native platinum-group metals; and silver, gold, and copper minerals (Morton, 1976). Although no grades or analyses of PGE at Cluff Lake have been published, "significant amounts of gold and platinum" have been reported (Robertson and Lattanzi, 1972). PGE in the Beaverlodge area have been reported at the Nicholson \#2 Zone. Here, uranium-gold-PGE mineralization is present in steeply dipping, carbonate-filled shear and fracture zones at the contact between white dolomitic quartzite and red ferruginous quartzite breccia of the Murmac Bay Formation. The highest PGE values are from a pitchblende-bearing shear zone juxtaposed with peridotite of the Nicholson Bay Ultramafic Complex. The mineralized zone has a minimum strike length of $50 \mathrm{~m}$ and a width of 5 to $50 \mathrm{~cm}$. Average grades are $136 \mathrm{ppm} \mathrm{Au}, 17.3 \mathrm{ppm} \mathrm{Pd}, 13.8 \mathrm{ppm}$ $\mathrm{Pt}$, and $0.4 \mathrm{ppm} \mathrm{Rh}$; there are also high concentrations of silver and bismuth (Hulbert, 1987). Other work in the Nicholson area has reported Pt values of 6.51 to $12 \mathrm{ppm}$ and Pd of $14.06 \mathrm{ppm}$ for three intercepts 0.9 to $1.6 \mathrm{~m}$ long (Kasner Group, 1987).

The Coronation Hill deposit in the South Alligator River area of Australia has platinum and palladium grades of 187 and $845 \mathrm{ppb}$, respectively (Wilde and others, 1989) with announced inferred resources, in 1986, of $34 \mathrm{t} \mathrm{Au}$ and about $2.5 \mathrm{t} \mathrm{Pt}$ and $5.3 \mathrm{t} \mathrm{Pd}$ (Hoatson and Glaser, 1989). Other deposits in the Coronation Hill area also contain PGE (Hoatson and Glaser, 1989). The Jabiluka deposit of the Pine Creek geosyncline, Australia, contains PGE and gold. Of 101 samples analyzed for PGE, 41 contain measurable platinum and 43 contain measurable palladium. The average Pt and Pd values for those 41 and 43 samples are 6.0 and $682 \mathrm{ppb}$, respectively. In the same suite, 53 samples contain measurable gold and have an average value of $15.4 \mathrm{ppm}$ (R.I. Grauch, written commun., 1991). The PGE and gold are present together in paragenetically late $\mathrm{Si}-\mathrm{U}-\mathrm{Te}-\mathrm{Re}$-rich veins (Grauch and others, 1985). Spatial and textural rela- tions suggested to Wilde and others (1989) that uranium, gold, and PGE were deposited during the same mineralizing event, transported in oxidized, slightly acidic, chloride-rich brines derived from Middle Proterozoic hematitic clastic rocks overlying the deposits; deposition occurred as these fluids were reduced in graphitic zones in the host rocks. Grauch and others (1985), however, have indicated that the age of the PGE mineralization is less well constrained and could be, but is not necessarily, much younger than the uranium mineralization.

\section{QUARTZ-PEBBLE CONGLOMERATE GOLD-URANIUM DEPOSITS}

This model expands upon that of Cox (1986a).

Descriptive Summary: Archean to Early Proterozoic placer deposits of gold, uranium, and PGE formed prior to oxidation of the atmosphere, which allowed the preservation and concentration of detrital pyrite and uranium minerals. Detrital minerals were locally remobilized or texturally modified during diagenesis and metamorphism. The famous Witwatersrand in South Africa will be used in most of the discussion below.

General References: Cox (1986a); Pretorius (1981); Tankard and others (1982).

\section{REGIONAL SETTING}

Tectonic Setting: Deposits of this type were formed on slowly subsiding cratons within epicontinental basins or half grabens. In some cases, such as in the stratigraphically high deposits in the Witwatersrand, multiple sedimentation cycles are evident (Tankard and others, 1982).

Regional Lithologic Characteristics: Clastic sedimentary rocks including sandstones, shales, and conglomerates comprise the sedimentary sequence within the basins. The sands are fluvial and lacustrine. Deposition occurred in alluvial fans within complex braided-stream systems rather than in a marine environment. Cross bedding is common and evidence of current or wave winnowing of the sediments is prominent. Volcanic units may be interbedded with the typically thick sedimentary units. Basement rocks are generally Archean granites or greenstones.

Age: Most deposits formed in the Late Archean to Early Proterozoic, before free oxygen became a major component of the Earth's atmosphere (Pretorius, 1981; Houston and Karlstrom, 1979).

\section{LOCAL SETTING OF ORE DEPOSITS}

Rock Types: Quartz-pebble conglomerate, and less commonly sandstone, host the deposits. These conglomerates are typically oligomictic and mature within a thick sequence 
of less mature conglomerate and sandstone. Conglomerates have a bimodal clast size of pebbles and matrix, where the matrix is composed of quartz, micas, chlorite, pyrite, and, in some conglomerates, fuchsite. Granitic clasts are absent.

Depositional Environment: Generally large alluvialfan systems, where stream gradients and bed load lessen, and ancient beaches that were winnowed by wave action are where deposits formed. Within the fan systems, gold and uranium ores are generally found in four sites (Guilbert and Park, 1985): (1) fan head or mid fan in sandy (plus pebbly) matrix at and near the base of fluvial conglomerate in channel fill; (2) midfan in pyritic trough cross-bedded sandstones, in erosion-deposition channels with ore minerals on forsets, in bottom-set spoons and scours, and in basal lag deposits; (3) midfan or upper-fan base as lag deposits in sheets of cross-bedded sandstones formed by winnowing of quartz to leave thin layers of heavy minerals, also along unconformities at the base of sedimentary units; and (4) fan base in carbonaceous layers on unconformities, in scour pools, and in algal mats.

\section{DESCRIPTION OF DEPOSITS}

Size: As with modern placers, the sizes of ancient placers vary. To be economic, however, the deposits generally must be large.

Mineralogy: Feather (1976) and Feather and Koen (1975) stated that about 70 ore minerals have been found in the Witwatersrand, 40 of which are of detrital origin. The most common and important minerals include gold, pyrite, uraninite, zircon, chromite, monazite, leucoxene, osmiumiridium alloys, isoferroplatinum, and sperrylite. Many mineral grains exhibit post-depositional alteration and some minerals are of secondary origin.

Ore Textures: The ore minerals are commonly disseminated throughout the matrix of the host conglomerate but rarely are also found along parting planes between minor unconformities and in quartz veins and dikes. Gold particles are typically 0.005 to $0.5 \mathrm{~mm}$ in diameter (Feather, 1976). They have been largely recrystallized during diagenesis and metamorphism.

Zoning: On a large scale at Witwatersrand, uraninite is found basinward of the gold distribution, but there is considerable overlap in location of the two commodities (Tankard and others, 1982). More locally within fans, the amount of conglomerate decreases and the amount of sandstone increases down gradient (Guilbert and Park, 1985). Along with this lithologic change, pyrite concentrations and grain size decrease, as does that of gold; net uranium and U:Au ratios increase; and algal material increases. The copperuranium-gold-rich layers may be only a few millimeters thick but are high grade (Guilbert and Park, 1985).

Ore Controls: Initial deposition of ore minerals was determined largely by characteristics of stream flow that govern the deposition of heavy minerals, as in modern placers. Carbonaceous layers, which may have been algal mats, at the bases of fans have uranium and fine gold (Cox, 1986a) but a genetic link between the carbon and the ore has not been substantiated. Many of the minerals are authigenic appearing and are not always concentrated in the conglomerate where expected on the basis of sedimentation hydraulics (Boyle, 1979), which suggests that minerals underwent later mobilization during diagenesis and metamorphism and were concentrated after relatively local migration into favorable porous sites within the host conglomerates.

\section{ECONOMIC CONSIDERATIONS}

Grade and Tonnage Models: Grade and tonnage models for these deposits have not yet been developed. The Witwatersrand represents uniquely enormous deposits of this type. Since its discovery in 1886, the six major gold fields with about 150 individual mines have produced about 55 percent of all the gold ever mined (Pretorius, 1976). About $700 \mathrm{t}$ of gold is produced annually along with significant amounts of uranium and byproduct PGE and silver. Average grades are $10 \mathrm{ppm} \mathrm{Au}, 280 \mathrm{ppm} \mathrm{U}$, and 3.5 ppb PGE.

Exploration Guides: Late Archean quartz-pebble conglomerates, especially if they represent multicycle deposits or if they are radioactive, are likely host rocks. Provenance may be important in determining whether gold, PGE, or uranium were available during sedimentation (Boyle, 1979).

Possible Associated Deposits: Homestake gold or low-sulfide gold-quartz veins in basement rocks may provide a source area for the gold. Some deposits are overlain by Proterozoic iron formation. Modern placers may have formed from erosion of fossil placer ores.

\section{PGE MINERALIZATION}

This information comes from the studies of Feather and Koen (1975) and Feather (1976) on the Witwatersrand deposits, where PGE are extracted as a byproduct of gold mining.

Economics: PGE were discovered in Witwatersrand in 1892 but they are extremely rare. They have an estimated combined grade of $3.5 \mathrm{ppb}$. Cousins (1973) indicated grades for PGE of 1.1 to $212 \mathrm{ppb}$ from deposits within the Witwaterstrand, but only 4 of the 57 deposits cited have grades greater than $15 \mathrm{ppb}$. Where PGE are abundant, Au:PGE is 100:1 and elsewhere, Au:PGE may be as high as $8,000: 1$.

Origin and Association: Ore minerals were originally detrital but subsequent alteration and remobilization 
resulted in the formation of secondary PGE minerals. PGE are associated with uraninite, chromite, and other heavy minerals.

Mineralogy: The most common PGE minerals are osmium and iridium alloys and native metals. Less common are ruthenosmiridium, ruthenian iridium, and traces of iridian ruthenium. Zoning and intergrowth textures are common, with osmium-rich cores and iridium- and, less commonly, platinum-rich outer parts where platinum-iron alloys are found (usually $\mathrm{Pt}_{3} \mathrm{Fe}$ ). Some altered PGE minerals contain unaltered inclusions of rhodium-platinum alloy, michenerite, moncheite, laurite, $\mathrm{RhS}_{2}$, palladium telluride, pentlandite, geversite, and ultramafic rocks. Sperrylite commonly surrounds alloy grains. Less commonly, hollingworthite, iridarsenite, and rutharsenite coat alloys and are themselves coated with sperrylite. Braggite and cooperite have been reported but not verified.

Geochemistry: Osmium and iridium are the most prevalent PGE. It is postulated that paladium, platinum, rhodium, and ruthenium were mostly lost during weathering and transportation to give a very mature osmium+iridium-rich sediment. Eighty percent of the PGE resides in iridium-osmium-ruthenium alloys and 15 to 20 percent is sperrylite and isoferroplatinum.

Ore Textures: Minerals are irregular to well rounded and rare crystal faces can be seen. The average grain size is 80 micrometers. The rounded grains are likely due to chemical leaching or accretion after deposition (in situ formation) rather than to abrasion during transport because of observed concentric phase zoning in some particles and the small sizes of some well rounded grains that are too small to have formed by rounding during transport (Cousins, 1973).

\section{BLACKBIRD COBALT-COPPER DEPOSITS}

Middle Proterozoic Blackbird cobalt-copper deposits contain massive and disseminated pyrite, pyrrhotite, arsenopyrite, cobaltite, chalcopyrite, magnetite, and minor amounts of other sulfide minerals in stratabound lenses and stringers and in quartz-tourmaline hydrothermal breccias hosted by metasedimentary rocks having a large mafic volcanic component (Earhart, 1986; Nash and Hahn, 1989). Several other papers provide background information about the Blackbird type of deposit, including Bennett (1977), Hahn and Hughes (1984), Hughes (1983), and Nash and Hahn (1986, 1989). Modreski (1985) described these deposits as being somewhat midway between volcanogenic massive sulfide and sediment-hosted copper deposits in their genesis, with the unusual characteristic of being highly enriched in cobalt. The presence of PGE was suggested by the copper and cobalt, with which PGE are commonly associated in other ore-forming environments. To date, however, PGE have not been found in substantial con- centrations in Blackbird cobalt-copper deposits. Analyses of seven samples from the area (M.P. Foose, oral commun. to M.L. Zientek, 1988) indicated $11 \mathrm{ppb} \mathrm{Pt}$ in one sample and $1 \mathrm{ppb} \mathrm{Pt}$ and $1 \mathrm{ppb} \mathrm{Pd}$ in another. The same set of samples has 2.3 to 9.4 percent $\mathrm{Co}, 0.53$ to 6.6 percent $\mathrm{Cu}$, and as much as $5 \mathrm{ppm}$ Au. The Sheep Creek deposit within the Belt Basin (Himes and Peterson, 1990) has a similar geochemical suite to the Blackbird deposits and opens up the possibility for the presence of Blackbird type deposits in rocks of the Belt Supergroup.

\section{SOUTHEAST MISSOURI LEAD-ZINC DEPOSITS}

These stratabound, carbonate-hosted deposits contain mostly galena, sphalerite, and lesser amounts of chalcopyrite in porous rocks located in reefs on paleotopographic highs (Snyder and Gerdeman, 1968; Briskey, 1986). Although Mississippi Valley-type lead-zinc deposits are widespread throughout the midcontinent of the U.S., the deposits in the Viburnum Trend and around Fredericktown in southeastern Missouri are of particular interest with respect to PGE because of their unusually high cobalt and nickel contents relative to Mississippi Valley-type deposits elsewhere. Jessey (1983) and Pignolet and Hagni (1983) provided details about cobalt-nickel mineralization. Siegenite is the most common cobalt-nickel mineral, but carrollite, nickelian carrollite, fletcherite, polydymite, vaesite, and bravoite are also present. The cobalt minerals commonly coat earlier-formed sulfide minerals such as chalcopyrite, marcasite, and pyrite. Spinels at lower stratigraphic levels within any given ore body contain relatively more copper and cobalt, whereas those higher in the sequence are more nickel rich. Grades have been reported as 0.2 percent $\mathrm{Cu}, 0.01$ to low tenths of a percent $\mathrm{Co}$, and 0.02 to 0.7 percent $\mathrm{Ni}$ (Heyl, 1982). A single sample collected from the Bonneterre Formation at the Sweetwater Mine in Madison County, Missouri, contains $16 \mathrm{ppb} \mathrm{Pd}$ with no detection of other PGE; the same sample contains greater than 2 percent $\mathrm{Cu}, 5,000 \mathrm{ppm} \mathrm{Ni}, 500 \mathrm{ppm} \mathrm{Co}$, and greater than 1 percent As (M.L. Zientek, oral commun., 1991).

\section{SOLUTION-COLLAPSE BRECCIA PIPE URANIUM DEPOSITS}

Sollution-collapse breccia pipes on the Colorado Plateau contain uraninite and associated sulfide, arsenide, sulfate, and arsenic-sulfosalt minerals disseminated or as replacements along fractures within the pipes (Wenrich, 1985; Wenrich and others, 1988, 1990; Finch, 1992). Grade and tonnage models have been developed based on data gathered from eight of the mineralized breccia pipes (Finch and others, 1992). PGE data for these deposits have not 
previously been reported; however, 25 samples submitted for analysis yielded some PGE values from the parts per billion to low tens of parts per billion range for $\mathrm{Pt}, \mathrm{Pd}, \mathrm{Rh}, \mathrm{Ru}$, and Ir; Os was not analyzed (K.J. Wenrich, written commun. to M.L.Zientek, 1989). The geochemical suite, particularly the cobalt and nickel in these deposits, and similarities in mineralogy and in possible fluid compositions to unconformity uranium-gold deposits suggested that PGE might be present. Mountain and Wood (1988a, b) and Wood and others (1989) have demonstrated that PGE may be transported and deposited from various hydrothermal fluids, including the kind of fluids that may have deposited minerals in the breccia pipes.

\section{PLATINUM-GROUP ELEMENTS IN COAL}

\author{
By Robert B. Finkelman and Susan J. Tewalt
}

\section{INTRODUCTION}

The map of U.S. coal basins (fig. 1) depicts the theoretical likelihood of PGE mineralization within each basin. The map is intended to portray areas in which PGE concentrations may be above background level for coal. Because there are an insignificant number of PGE analyses for coal, the map was constructed essentially from geological and geochemical principles believed to govern PGE behavior. Although the map is not intended to convey any economic significance, it may indicate areas where coal could be a host to PGE or, more likely, an indicator of PGE mineralization.

Coal may present an ideal environment for trapping and accumulating available PGE. Several reasons support this contention; among them are:

1. The abundance of sulfide minerals in coal and the strong siderophile nature of PGE (Goldschmidt, 1954). Sulfide minerals constitute about 2 wt percent of all U.S. coals. Some coals, however, contain as much as 10 wt percent sulfide minerals. Almost 30 sulfide minerals have been reported from coal, pyrite and marcasite being, by far, the most common. Sphalerite and galena are present in most coals and are major components of some midcontinent coals. Commonly, sulfide minerals are found in the cleat or fractures in coal and are, therefore, readily separated. Some waste products of coal-cleaning plants contain in excess of $40 \mathrm{wt}$ percent sulfide minerals (Wewerka and others, 1978).

2. The abundance of chalcophile elements in coal. Buchanan (1988) noted that PGE readily combine with antimony, bismuth, selenium, and tellurium. These are among the most highly concentrated elements in coal with respect to crustal abundances (unpub. data from the U.S. Geological Survey's National Coal Resources Data System).

3. The propensity for organic matter to form PGE complexes. Ong and Swanson (1969) speculated that colloidal platinum in contact with organic acid would form colloidal precipitates. Also, plants themselves can take up PGE.
Dunn (1986) demonstrated the relative enrichment of platinum and palladium in twigs and trunks of several types of trees. He suggested that biogeochemical prospecting could be a useful tool for locating concealed PGE deposits. It is logical to assume that coal (fossil plants) can be used for the same purpose.

4. The natural filtering and baffling action of plants and peat. Fine-grained water-transported PGE-bearing particles could be physically trapped either by plants or by peat. This process may have contributed to the inclusion of detrital gold (Finkelman, 1981) and even detrital diamonds (Finkelman and Brown, 1988) in coal.

5. Interaction of carbonaceous material with PGEbearing solutions. Macdonald (1987) implied that organic matter may have played a key role in the formation of many late-diagenetic/epithermal PGE deposits. Kucha (1982) suggested that PGE in the Kupferschiefer shales were concentrated during late-diagenetic fluid flow by auto-oxidation and desulfurization of the organic matter. Even in metamorphosed areas, carbonaceous material in schists may have acted as a reductant to precipitate PGE (Needham and StuartSmith, 1987).

The association of platinum with organic matter is discussed by Parnell (1988), who found submicrometer particles of native platinum in a pyrobitumen from New York.

\section{PGE IN COAL}

Despite these compelling reasons to look for PGE associated with coal, few data exist. Older literature, based primarily on spectrographic analyses of coal ash by Goldschmidt and Peters (1933), reported several hundred to $1,000 \mathrm{ppb} \mathrm{Pt}$ in the ash. Values for osmium, palladium, and rhodium generally were between 20 and $500 \mathrm{ppb}$ in the ash. Because many coals have about 10 wt percent ash, these data indicate concentrations of PGE in coal of 2 to $100 \mathrm{ppb}$. Block and Dams (1975) found 7 to 9 ppb iridium in Belgian coals. Ruch and others (1979) analyzed 18 U.S. coals and their residues from coal liquefaction processes. In all their samples, platinum values were below the $5 \mathrm{ppb}$ detection limit. Palladium values were less than 3 $\mathrm{ppb}$ from most samples, with one coal having $47 \mathrm{ppb}$.

Finkelman and Aruscavage (1981) found platinum to be less than $2 \mathrm{ppb}$ in six of the eight U.S. coal samples they analyzed. The other two coals, from North Carolina and Indiana, had $6 \mathrm{ppb}$ Pt. The coals from North Carolina also had $3 \mathrm{ppb}$ Pd. Palladium and rhodium were below the limit of detection (1.0 and $0.5 \mathrm{ppb}$, respectively) in all the other samples. Chyi (1982) analyzed for platinum in 65 low-temperature ash samples from the Kentucky No. 9 coal. He found platinum above the detection limit of $1 \mathrm{ppb}$ in 25 samples with a maximum of $210 \mathrm{ppb}$, calculated to a coal basis. Chyi concluded that platinum was enriched in coal by a factor of 18 compared to crustal abundances ( $2 \mathrm{ppb})$. 


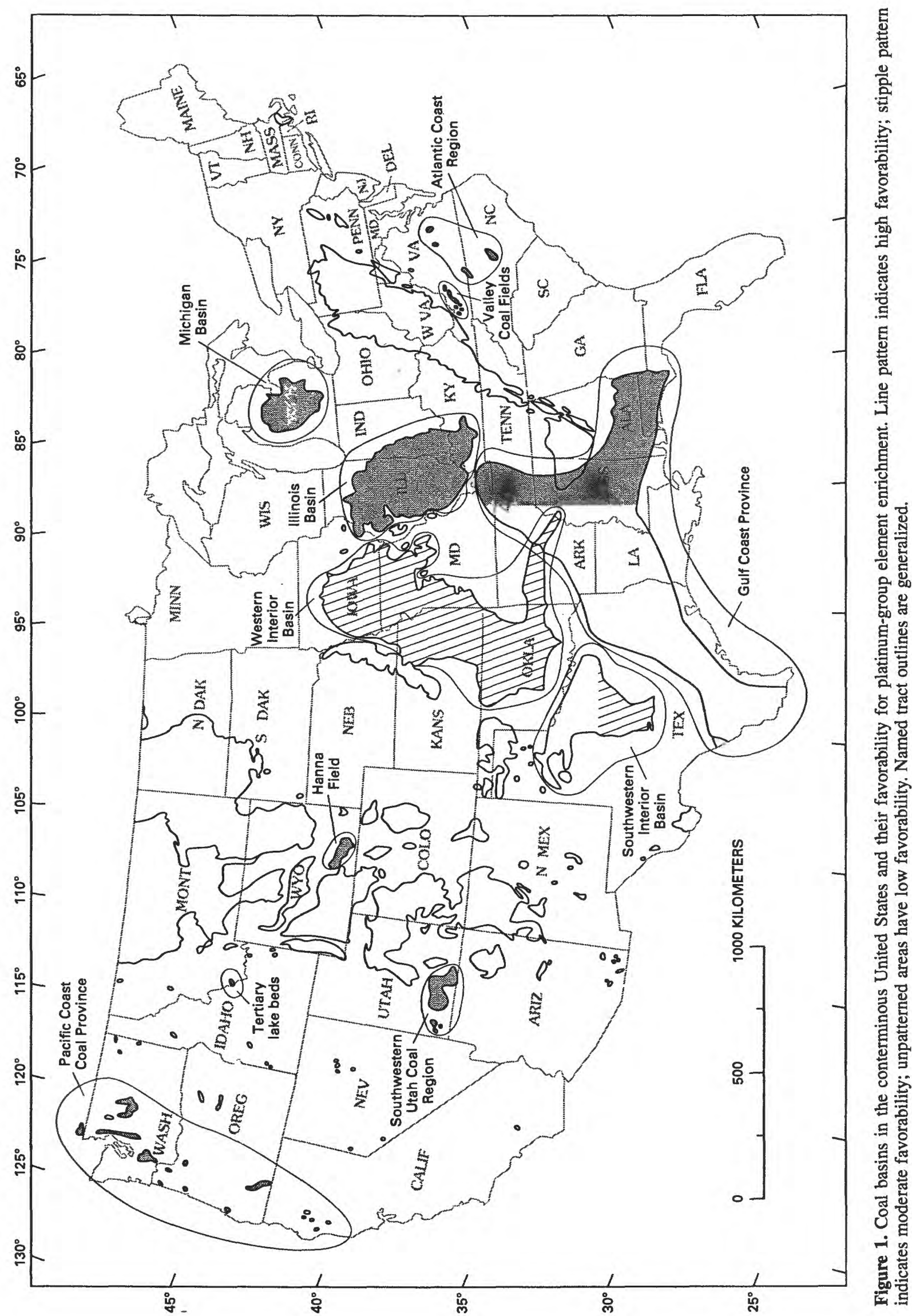


Van Der Flier-Keller (1990) summarized results (Van Der Flier-Keller and Fyfe, 1987; Van Der Flier-Keller and Goodarzi, 1988; Van Der Flier-Keller, 1991) on 97 coal samples from seven Cretaceous and Tertiary coal deposits in Canada. She concluded that most of the PGE concentrations were below the limits of detection (less than or equal to 5 $\mathrm{ppb})$. Anomalously high concentrations were found in samples from the Quinette deposit in British Columbia (B.C.) and from the Blackburn Mine, Tulameen, B.C., near the platinum-rich Tulameen ultramafic complex.

The high PGE concentrations (1,700 ppb Pt and 180 $\mathrm{ppb} \mathrm{Rh}$ ) in the Quinette samples were found in the uppermost coal, in contact with overlying conglomerates. The high concentrations (greater than $10,000 \mathrm{ppb} \mathrm{Pt}$ and 6,100 $\mathrm{ppb}$ Pd) in the Blackburn Mine were found in fault-related coal samples. Van Der Flier-Keller (1990) suggested that the porous conglomerates and the permeable fault zones enhanced groundwater flow, resulting in greater contact between the coal and PGE in the water.

The high PGE concentrations in the Blackburn Mine samples were determined by lead fire-assay direct-current spectroscopy. Splits of these samples analyzed by nickelsulfide fire-assay neutron activation analysis showed no PGE enrichment. Van Der Flier-Keller (1990) suggested that these differences may be related to within-sample variability and (or) variations in sample preparation and analytical procedures.

During the past few years the controversy concerning the Cretaceous-Tertiary (K-T) boundary has focused on the iridium anomaly in the boundary clay. Several terrestrial occurrences of the boundary clay have been found in western North America. In some of these locations, the boundary clay is associated with coal. Analyses of these coals indicate iridium background levels of 0.005 to $0.1 \mathrm{ppb}$; near the boundary clay the iridium levels are as high as $0.3 \mathrm{ppb}$ (C.L. Pillmore and C.J. Orth, oral commun., Feb. 1989). Gilmore and others (1984) noted that, at all of the five nonmarine K-T boundary areas they studied, the highest iridium values were found in the coal above the boundary clay. They attributed this displacement to a physical mixing of iridium-bearing particles with plant matter and to chemical migration of the iridium in the acid environment associated with the transformation of plant matter to coal.

The low (less than $0.1 \mathrm{ppb}$ ) values for PGE in coal associated with (but not adjacent to) the boundary clay may be typical of low-sulfur coal having no marine influence. Coals having higher sulfur (greater than $1 \mathrm{wt}$ percent) values and (or) marine influence may have PGE values in the 1 to $100 \mathrm{ppb}$ range.

\section{RATIONALE FOR PGE-COAL BASINS MAP} (FIG. 1)

The absence of more complete analytical data on PGE in coal required that we base our map on fundamental geo- logic and geochemical principles. Using information in the National Coal Resource Data System, we determined for each coal basin the average values for the following factors: (1) organic sulfur content (dry basis); (2) pyritic sulfur content (dry basis); (3) the sum of nickel, cobalt, copper, and vanadium content; (4) the sum of lead and zinc content; (5) the silver content; (6) proximity to areas of known PGE mineralization (based on data from Blair and others, 1977).

We identified the basins having the highest values for each of these factors, which were given equal weight. The Western Interior coal basin and the southern part of the Southwestern Interior basin have high values for four of the factors and are, therefore, considered to have a high likelihood of PGE enrichment. The Illinois Basin, eastern part of the Gulf Coast Province, Pacific Coast Coal Province, Tertiary lake beds in Montana, Valley Coal Fields, Atlantic Coast Region, Michigan Basin, Hanna Field, and Southwestern Utah Coal Region all have high values for one or two of the factors. These basins are considered to have a moderate likelihood for PGE mineralization. All the remaining coal basins have a low likelihood of PGE mineralization.

\section{CONCLUSIONS}

The association of PGE with coal presents several opportunities. The remote possibility exists for ore-grade concentrations of PGE in coal. Alternatively, processes could be developed to extract PGE and other byproducts from coal or coal wastes. Unfortunately, there is little information on the PGE content of coal wastes. As the ash yield of coal is commonly 5 to 15 percent, it is likely that PGE would be relatively enriched in the waste products. Although current PGE data are too sparse for firm conclusions concerning PGE coal geochemistry, it appears likely that coal would be more useful as a biogeochemical indicator of PGE mineralization than as a host. Although coal has the potential for complexing and concentrating PGE, a key factor influencing PGE abundances in coal would be their availability (mobility) during the development of the coal and its peat precursor. Even if none of the possibilities discussed above occur, the association of PGE with coal should help us to better understand the low-temperature geochemistry of these elements.

\section{DISCUSSION OF TRACT DESIGNATIONS FOR PGE IN SEDIMENTARY ENVIRONMENTS}

The sections that follow provide a brief statement of the rationale for delineating particular tracts (shown on plate 1, maps 1 and 2) as permissive for PGE in specified 
deposit types in sedimentary rocks. The tracts shown on the plate and figure 2 do not extrapolate into the subsurface except in the case of the solution-collapse breccia pipes, because doing so would have greatly complicated the compilation and its presentation. References are not generally cited in the discussion below; however, table 1 provides references for the geologic maps and geologic literature. It also gives mineral deposit information and locations used in constructing the tracts. The table is organized according to deposit type in the same order as presented in the models above, and entries under each deposit type roughly present the more important environments first, where such a distinction can be made. Additional explanations, to supplement table 1 , for specific tracts are included in the following text. This includes information about PGE analyses for localities within the tracts where such data are available. Samples collected from deposits within many of the tracts have not been analyzed for PGE; unless specific data are presented, assume that no PGE data are available for a given tract. In some cases, comparisons of a particular deposit type or specific tract are made with foreign deposits known to contain PGE to emphasize important differences or similarities; in other cases, unique features of certain tracts are noted.

\section{PLACER AREAS (MAP 1, PL. 1)}

Known PGE-bearing gold placer deposits (table 1) are abundant in the Sierra Nevada of California (tract 1, map 1) and the Klamath Mountains of California and Oregon (tract 2, map 1). Two other areas that have numerous PGE-bearing placer accumulations are Pacific coastal sands (tract 3, map 1) and northeastern Oregon (tract 4, map 1). Scattered localities elsewhere throughout the U.S. are reported to have small PGE-bearing placer accumulations. Of particular note are the PGE occurrences in North Carolina and Georgia that have been found in a region of former gold placering and the single occurrence in New York. Because the North Carolina and Georgia occurrences are also in a region of mafic and ultramafic rocks, further investigation of stream sediments may reveal a more widespread distribution of PGE. Likewise, the occurrence in New York came from a glacial erratic, suggesting that till deposited in the state may have been picked up in a suitable source region and may contain other occurrences of PGE. Many PGE minerals in placers are not traceable to specific lode deposits or source areas. An exception is reported PGE in placers associated with the New Rambler and Centennial Ridge districts in southeastern Wyoming.

The main placer areas in the western U.S. have been variously delineated, and specific placer localities have been marked with a dot (map 1). These placers have been derived from both modern stream gravel and, particularly in the Sierra Nevada, from Tertiary gravels remaining from older drainage systems. To delineate areas permissive for modern placer gravels in the Klamath Mountains, Sierra Nevada, and northeastern Oregon, the rivers shown on the compilation base map are highlighted along their drainage from exposed ultramafic rocks within the drainage basin to the base of the range (or to the ocean), where gradients significantly decrease. This does not necessarily indicate that all the PGE in placers are derived from ultramafic rocks, because it is likely, particularly in the Sierra Nevada, that PGE came from other sources such as lowsulfide gold-quartz veins. Some placers in scattered localities are described in the literature as if gold does not accompany the PGE. However, the geologic settings for most of these placers are dissimilar to settings from which important PGE-gold placers are derived, and those few that do have appropriate source terranes do not fit the grade and tonnage characteristics of the PGE-gold placers as defined by Singer and Page (1986).

\section{SEDIMENT-HOSTED COPPER TRACTS (MAP 1, PL. 1)}

Using descriptive characteristics of sediment-hosted copper deposits (see model above) and locations of known sediment-hosted copper occurrences within the U.S., 10 permissive regions were defined (map 1; table 1). Some of the regions have had productive copper deposits; others contain uneconomic copper concentrations; one has no known copper occurrences, but the sedimentary succession suggests an appropriate environment for such deposits. None of these areas are presently known to contain more than a few parts per billion PGE, but well-known environments of this type in Poland and Germany (Kupferschiefer) and Zambia and Zaire (Copperbelt) contain sufficient PGE to constitute byproducts of some mining operations. Thus, it is important to recognize and examine similar environments in the U.S. However, the known sediment-hosted copper deposits in the U.S., based on descriptions in the literature, appear to have simpler ore mineralogy than the large, well-known foreign deposits, and they lack signifcant concentrations of associated commodities such as cobalt. Without detailed chemical analyses of samples from U.S. deposits, it cannot be determined whether the seemingly simpler mineralogy is also associated with a geochemical suite less favorable for the presence of PGE.

\section{MIDCONTINENT REGION (TRACT 5, MAP 1)}

Permian redbed sequences in the midcontinent extend from central Texas into southern Nebraska and include several formations known to contain copper concentrations, the most important being the Flowerpot Shale, 


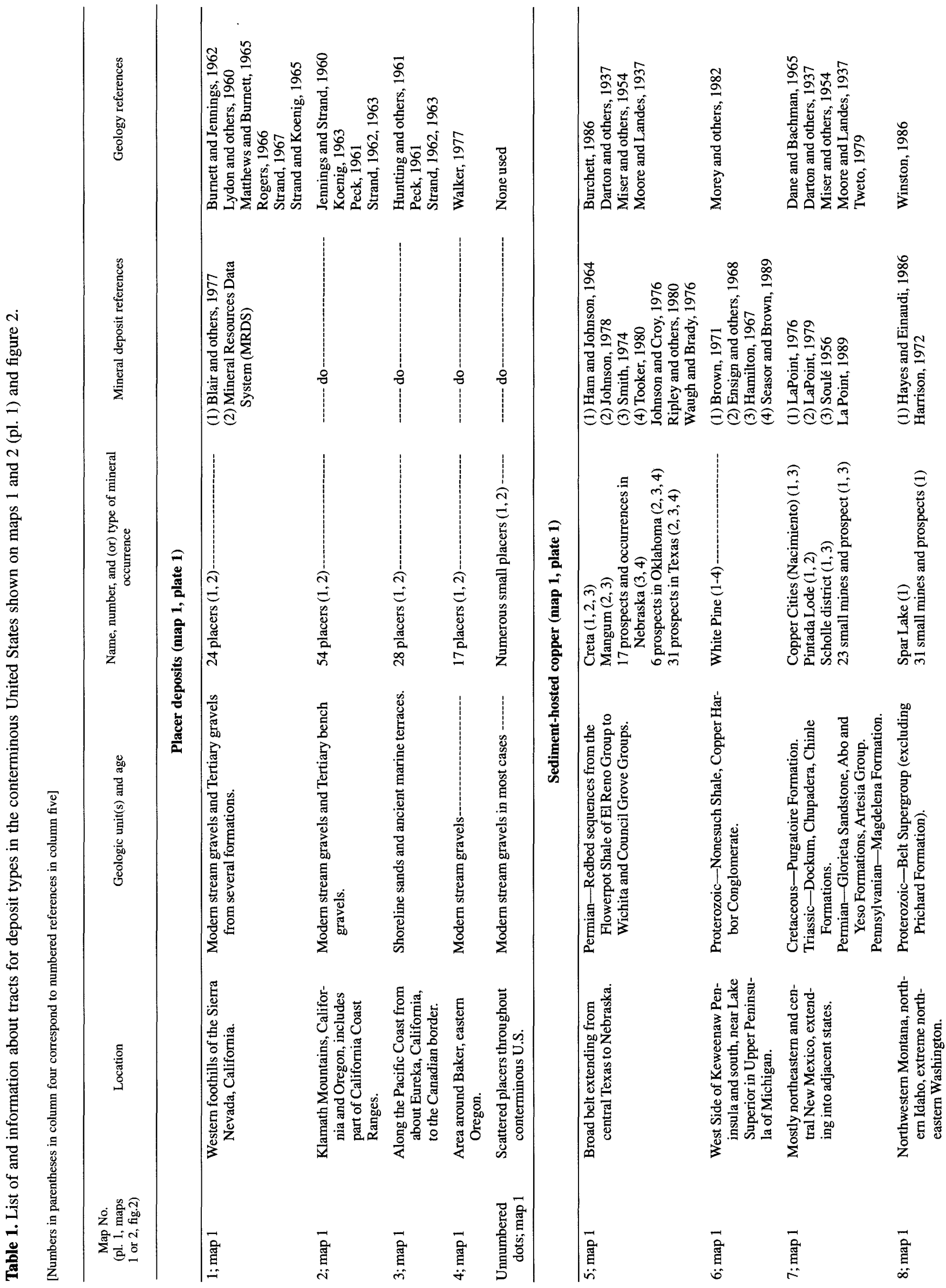



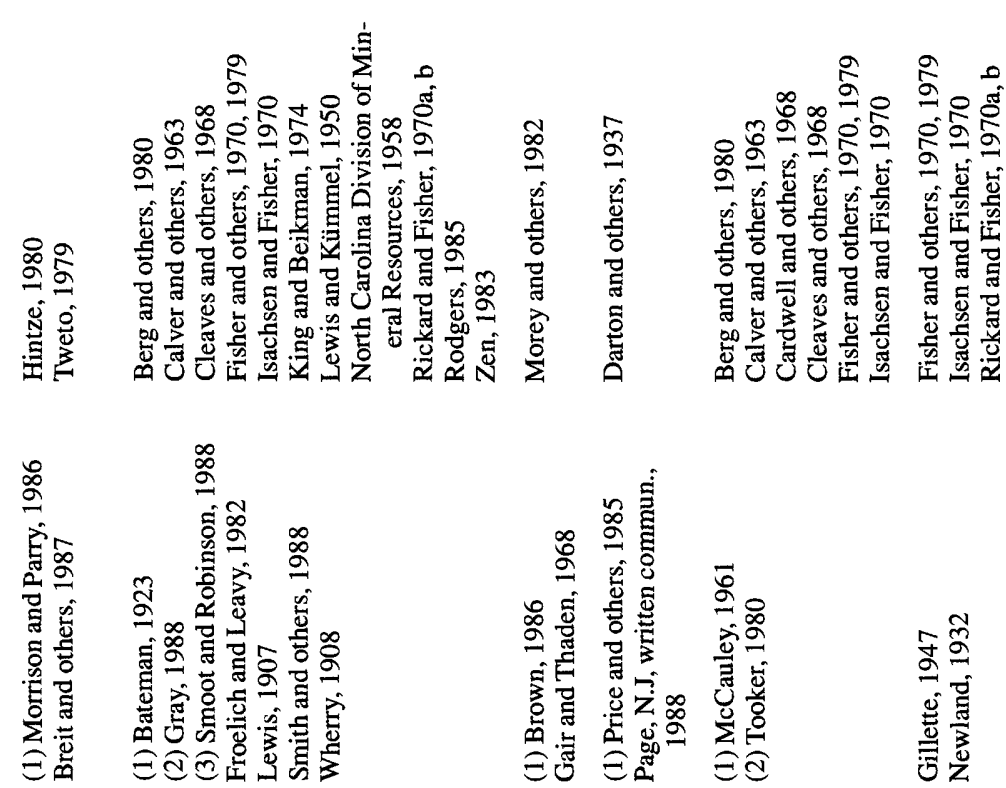

|con
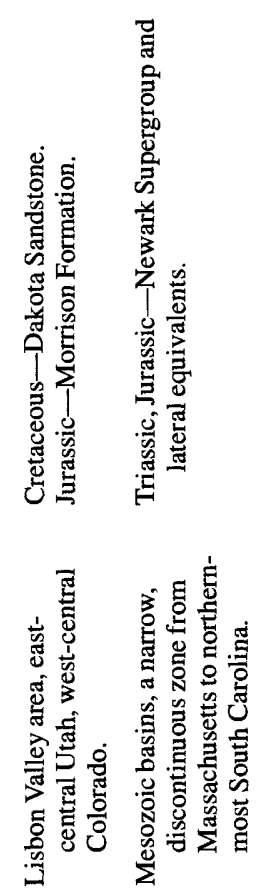

$\begin{array}{ll}\overrightarrow{0} & \overline{0} \\ \text { 鄫 } \\ \text { a }\end{array}$

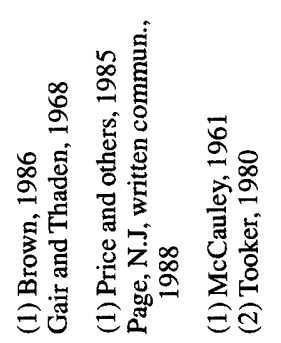

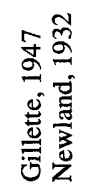
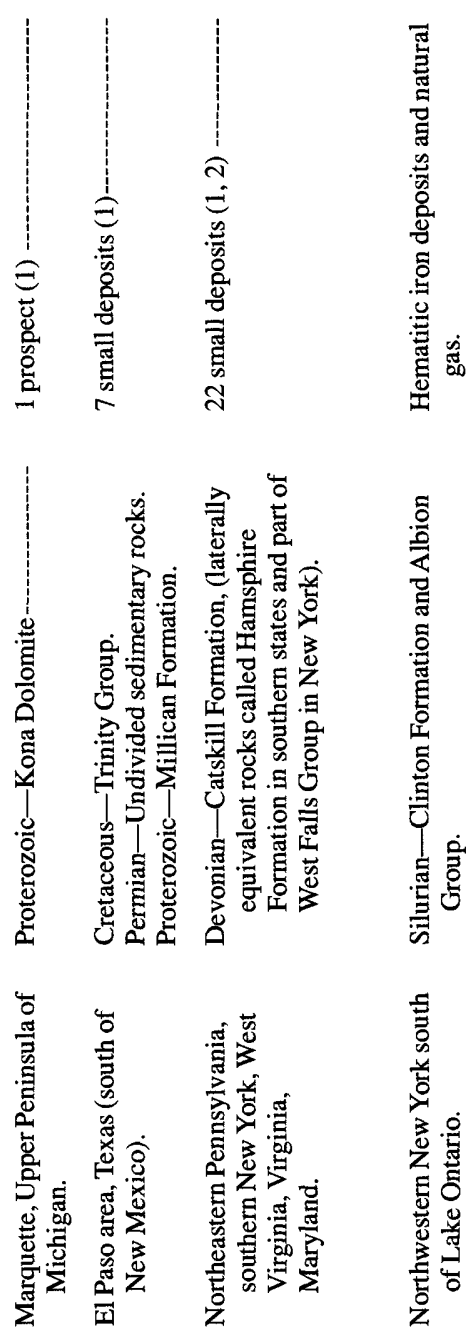

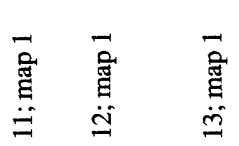
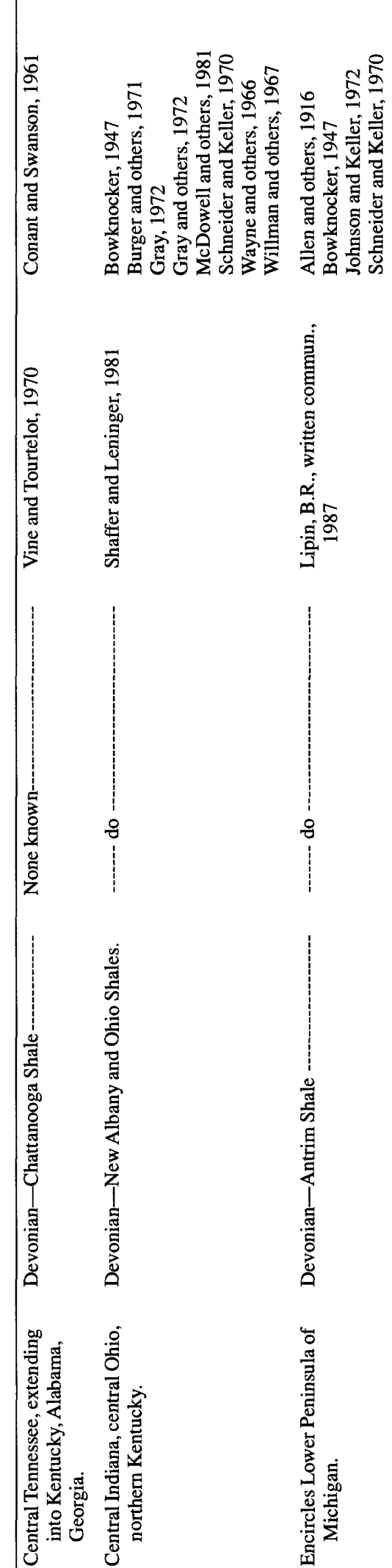

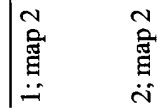




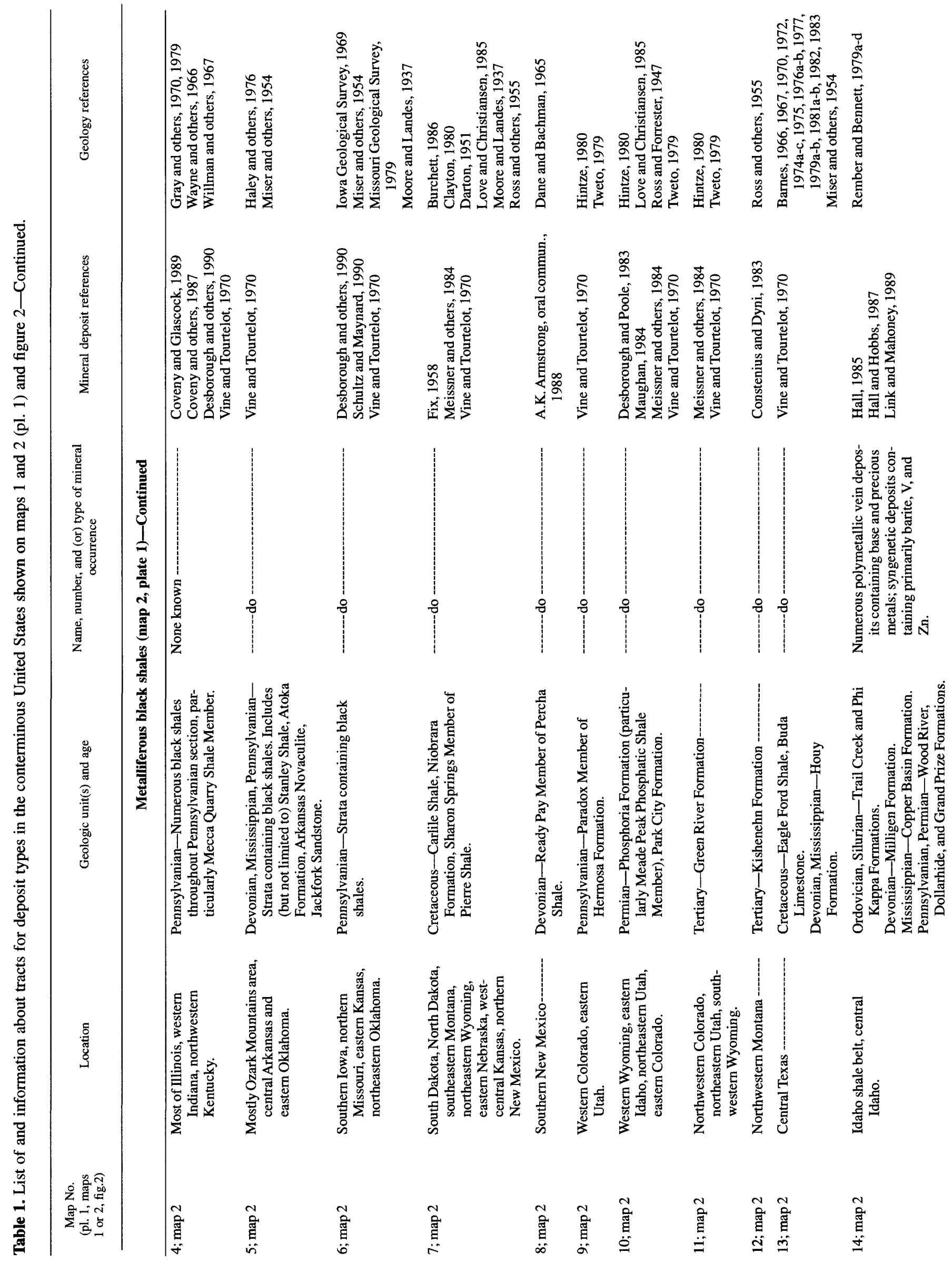




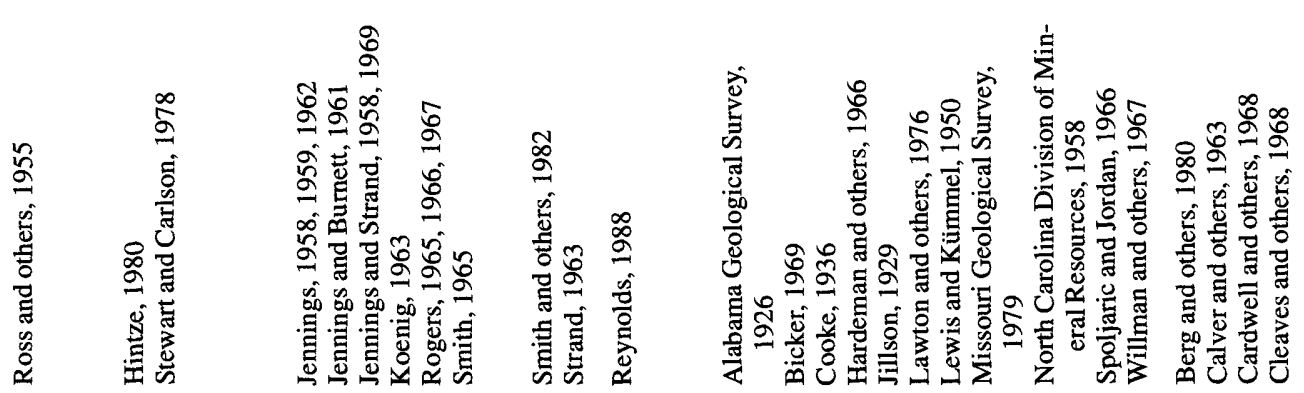
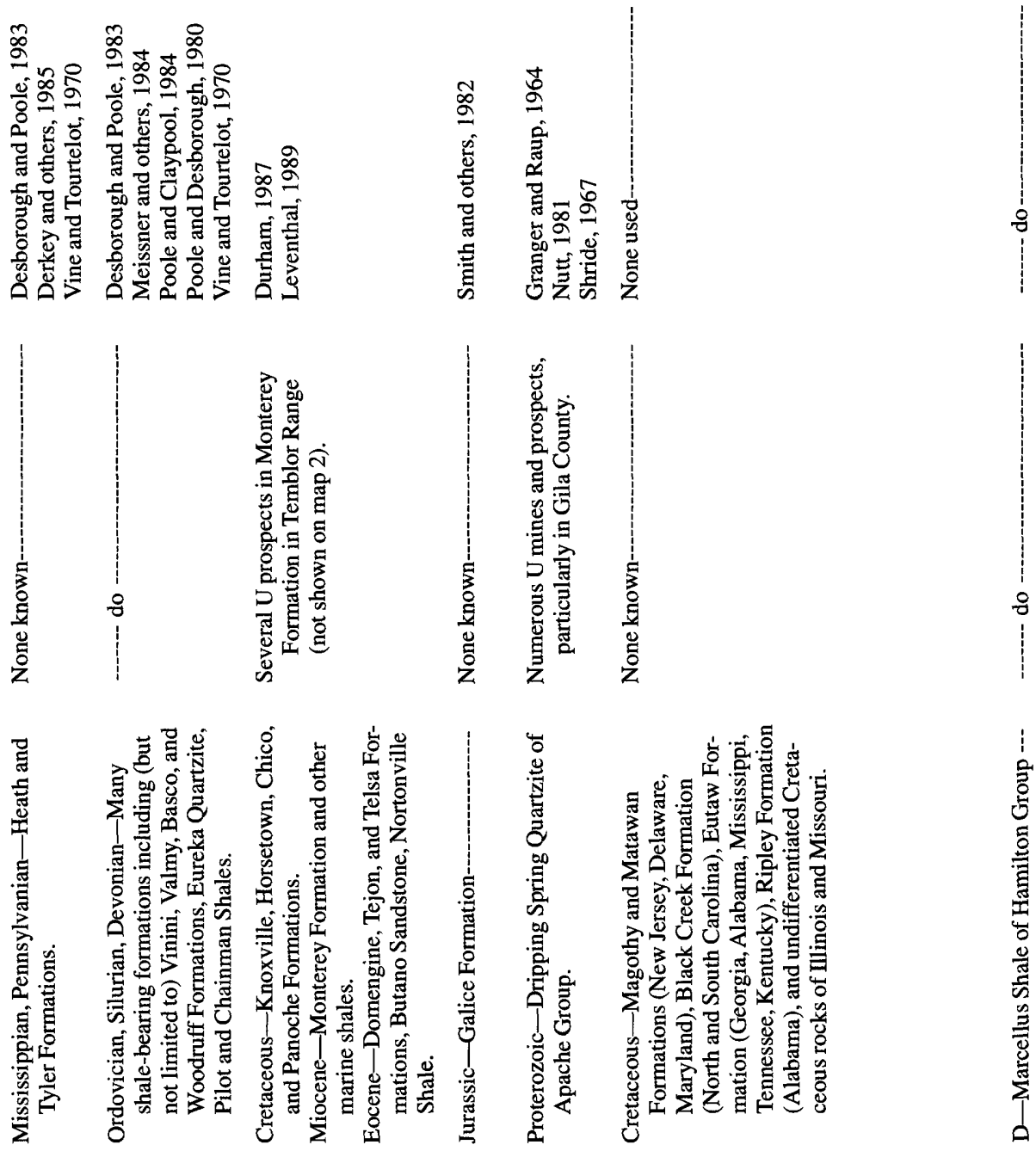

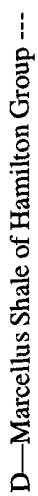

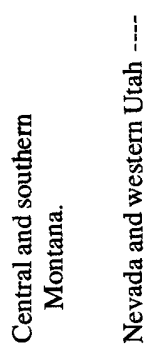
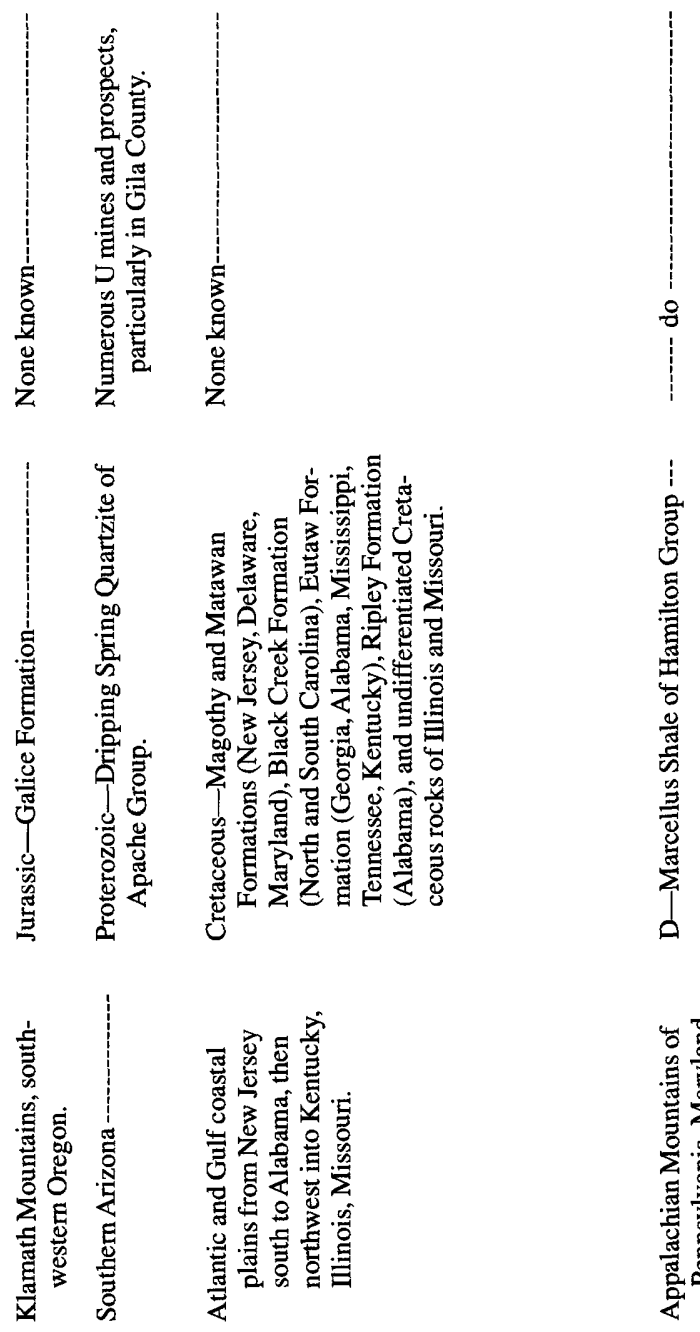

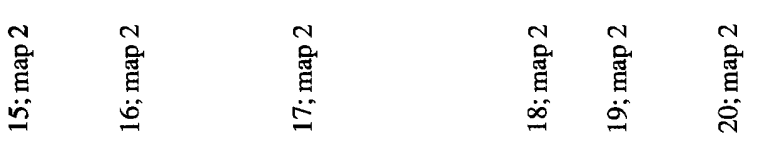

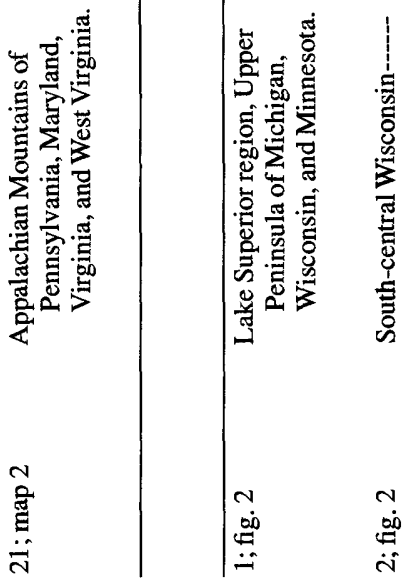




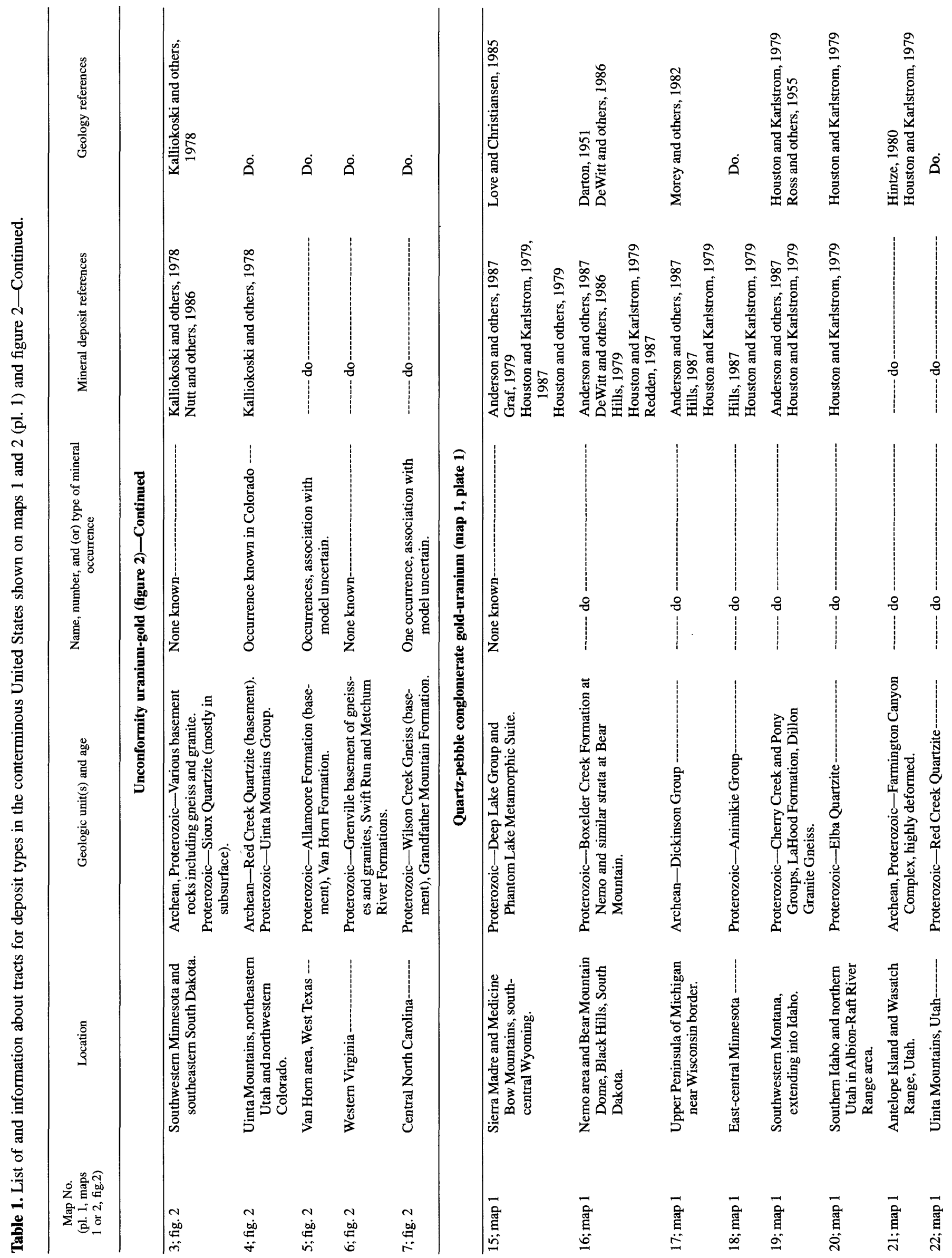


which is host to the formerly productive Creta and Mangum deposits (map 1, deposits a and b). There are also several other organic-carbon-rich black shales within the redbed section. Most of the mines and prospects are in Texas and Oklahoma, and although small prospects and occurrences are also present in southern Kansas, the stratigraphic interval over which known copper occurrences are present is greater in Oklahoma and Texas. Analyses of 13 samples from near Creta indicate that PGE are present in small quantities. Nine samples have 0.7 to $1.2 \mathrm{ppb} \mathrm{Pt}$ and two have $0.8 \mathrm{ppb}$ Pd. Additionally, one mill concentrate contained $11 \mathrm{ppb}$ Pt, $8.5 \mathrm{ppb}$ Pd, and 2 ppb Rh.

\section{NONESUCH SHALE (TRACT 6, MAP 1)}

The Proterozoic Nonesuch Shale in the Keweenaw Peninsula of the Upper Peninsula of Michigan contains the White Pine deposit (map 1, deposit c). Plate 1 depicts only the Nonesuch Shale, but the uppermost part of the underlying Copper Harbor Conglomerate is also mineralized (Hamilton, 1967; Seasor and Brown, 1989). Other deposits have not yet been found in the Nonesuch Shale. The shale possibly underwent two stages of mineralization, an earlier chalcocite stage and a later native-copper stage (Jeff Mauk, oral commun., 1989). The native-copper mineralization may have been part of the basaltic copper mineralization of the underlying Portage Lake Volcanics. Of nine samples analyzed from the Nonesuch Shale, platinum values are 1.1 to $3.3 \mathrm{ppb}$ and palladium values are 1.4 to $4.0 \mathrm{ppb}$.

\section{NEW MEXICO REGION (TRACT 7, MAP 1)}

This area includes numerous redbed formations ranging in age from Pennsylvanian through Cretaceous that crop out mostly in central and northeastern New Mexico and extend into adjacent parts of Texas, Colorado, Oklahoma, and Kansas. Because of the complex geology of New Mexico, parts of the units shown on plate 1 have been generalized and simplified to retain usability. The region includes several important copper deposits and districts, including Copper Cities (Nacimiento), Pintada Lode, and Scholle (map 1, deposits d, e, and f), hosted by Permian and Triassic strata. Mineralization in sequences of other ages (Pennsylvanian and Cretaceous) is less well developed and generally uneconomic.

\section{BELT SUPERGROUP (TRACT 8, MAP 1)}

The Proterozoic Belt Supergroup of Montana, Idaho, and Washington is composed of a thick sedimentary sequence known to contain numerous copper occurrences and deposits. The Prichard Formation, lowermost unit of the Belt, is not known to contain copper mineralization and does not appear to be favorable for sediment-hosted 
copper deposits; therefore, it is not shown for this deposit type. The Revett Formation within the Ravalli Group contains the known economic deposits (Harrison, 1972). Belt strata overlying the Ravalli Group contain copper concentrations which are currently uneconomic. The Spar Lake deposit (map 1, deposit g), an important copper deposit in the Belt, has received recent careful study of the diagenetic nature of the formation of the deposit (Hayes and Einaudi, 1986).

\section{LISBON VALLEY (TRACT 9, MAP 1)}

The area surrounding Lisbon Valley in eastern Utah and western Colorado presents a unique type of sedimenthosted copper deposit in which the mineralizing fluids migrated along major faults out of the redbed sequence and into younger host rocks. In this case, the fluids are thought to have been derived from the Pennsylvanian Hermosa Formation and moved into the Jurassic Morrison Formation and the Cretaceous Dakota Sandstone (Morrison and Parry, 1986; Breit and others, 1987). Both host formations are extensive throughout the western U.S. but are shown as sedimenthosted copper tracts only in the vicinity of Lisbon Valley near areas of known mineralization, where the units are probably underlain by the Hermosa Formation.

\section{MESOZOIC BASINS (TRACT 10, MAP 1)}

The Mesozoic Basins in the eastern U.S. extend from Massachusetts to North Carolina subparallel to the Atlantic coastline. These basins contain several types of mineral deposits including some that have been classified as sediment hosted (Smith and others, 1988; Smoot and Robinson, 1988). However, the geologic environment of the basins differs in one important aspect from the classic sediment-hosted copper environment; sediment-hosted deposits are most commonly deposited in the first major marine transgression overlying the redbed sequence (see model), whereas the Mesozoic basins are filled with lacustrine sequences. It is not known what, if any, effect this might have had on associated mineral deposits.

\section{KONA DOLOMITE (TRACT 11, MAP 1)}

The Kona Dolomite, part of the Proterozoic Chocolay Group, is located in the Upper Peninsula of Michigan near Marquette. The presence of one copper prospect and similarities to the dolomitic host rocks in the Copperbelt of Zambia and Zaire suggest that this unit should be considered with the sediment-hosted copper environment. Similarities of the Kona Dolomite with the Copperbelt rocks include stromatolytic dolomite suggesting an intertidal environment, interbeds of slate, presence of pyrite and other sulfide minerals, and mineral deposition in a sabkha environment.

\section{WEST TEXAS (TRACT 12, MAP 1)}

The westernmost part of Texas south of New Mexico contains several redbed sequences (see table 1). Although the known copper deposits in this area are veins, geologic characteristics of the redbed sequences led a team of U.S. Geological Survey scientists in a preliminary unpublished mineral assessment of the areas to delineate these units as being permissive for sediment-hosted copper deposits (N.J Page, written commun., 1988).

\section{CATSKILL FORMATION (TRACT 13, MAP 1)}

The Catskill Formation, although relatively unmineralized when compared to the tracts discussed above, has permissive lithologic characteristics such as redbeds and reduced horizons and small copper-uranium prospects (McCauley, 1961), which merit its inclusion as an area permissive for sediment-hosted copper deposits.

\section{NORTHWESTERN NEW YORK (TRACT 14, MAP 1)}

The Silurian Clinton Formation and Albion Group south of Lake Ontario have been included as permissive for sediment-hosted copper deposits because they contain minor redbed sequences and black shales. However, the shales do not directly overlie the redbeds but are commonly interbedded with other sandstones and calcareous rocks above the redbed sequence. Above these units the Salina Group consists of evaporite deposits. No copper occurrences are currently known in these units but hematitic iron deposits are common in the Clinton Formation and natural gas has been produced from rocks of the Albion Group (Newland, 1932; Gillette, 1947).

\section{METALLIFEROUS BLACK SHALE TRACTS (MAP 2, PL. 1)}

Innumerable black-shale units are present throughout the U.S. that range in age from Ordovician to Tertiary. All are thin units impossible to show at the scale of map 2. Therefore, black-shale tracts are shown as the major stratigraphic units within which the shales are found. In some cases, particularly for Pennsylvanian strata, which contain many black shales, the entire stratigraphic sequence was outlined to show the general area in which the shales are present. Probably some areas underlain by black shales have inadvertently been omitted, because a comprehensive knowledge of the geology of the entire country would be 
needed to delineate all black shales. I also did not include metamorphosed shales such as the Ledbetter Slate in the Metaline district of Washington or the slates of the Carolina slate belt even though these and similar slates may be metamorphosed equivalents of organic-carbon-rich shales. However, I did include most of those shales studied by Vine and Tourtelot (1970) and by Desborough and Poole (1983), other shales that were noted as organic-carbon rich in the literature, and units on state geologic maps that could possibly fit the model for shales permissive for PGE.

I have delineated 21 areas of black shales. One black shale known to contain PGE is a Mississippian unit in southeastern Oklahoma (in tract 5, map 2) (Orth and others, 1988). Few black shales in the U.S. have been analyzed for PGE. The areas outlined on plate 2 do not repeat black shales associated with redbed sequences that are included in tracts for sediment-hosted copper deposits. Only selected tracts are discussed below; see table 1 for the general information about each tract.

\section{PENNSYLVANIAN SHALES OF THE MIDWEST (TRACT 4, MAP2)}

The Pennsylvanian section of Illinois, Indiana, and northwestern Kentucky contains many thin black shale units, at least one of which (the Mecca Quarry Shale Member of the Linton Formation of Rainer and Richardson, 1963) is known to be enriched in metals (Coveny and Glascock, 1989). Because the shales are thin and because they are found throughout the entire Pennsylvanian section, the complete section was delineated on the map. The black shales of interest comprise only a small part of the area shown.

\section{SHALES OF THE EASTERN PLAINS STATES (TRACT 6, MAP 2)}

Southern Iowa, northern Missouri, and eastern Kansas have extensive outcrops of Pennsylvanian strata containing black shale. Equivalent strata extend into northeastern Oklahoma and cross the state. The delineated area was rather arbitrarily cut off in northeastern Oklahoma because it was difficult to determine from the state geologic map of Oklahoma whether the black shales within the Pennsylvanian strata there continued to the south. Thus, the area of black shales may extend farther south than shown. Twelve analyses of shales from Kansas yielded low parts per billion (less than $10 \mathrm{ppb}$ ) values for platinum and palladium in most samples and low parts per billion values for ruthenium in three samples.

\section{NORTHERN PLAINS SHALES (TRACT 7, MAP 2)}

The Cretaceous Carlile and Niobrara Formations and Pierre Shale are extensive throughout the northern plains states. It was difficult to trace these units into North
Dakota, where glacial cover is present nearly everywhere except in major stream drainages, and into Minnesota, where all Paleozoic and younger units are very generalized on geologic maps.

\section{PHOSPHORIA FORMATION (TRACT 10, MAP 2)}

The Permian Phosphoria Formation presented somewhat of a dilemma in classifying it with a particular deposit type. There are some red sandstones within it; yet, the unit is not commonly included in discussions of sediment-hosted copper environments. The large phosphate content sets it apart from most sequences in which black shales are found. However, its Meade Peak Phosphatic Shale Member has a high organic-carbon content and was considered a black shale by Vine and Tourtelot (1970). Therefore, I have included it with black shales. As noted in an earlier section, five samples of this member contain 1.6 to $2.0 \mathrm{ppm}$ Pd. Map 2 shows generalized locations of the outcrops of the Phosphoria Formation; the organic-carbon-rich member is only a small part of it.

\section{GREEN RIVER FORMATION (TRACT 11, MAP 2)}

The Tertiary Green River Formation of lacustrine rather than marine origin is known not only as a black shale but also as an oil shale (Meissner and others, 1984).

\section{KISHENEHN FORMATION (TRACT 12, MAP 2)}

Oil shale within the Oligocene Kishenehn Formation (Constenius and Dyni, 1983) has been compared to that in the Green River Formation. There is no data on the trace metal content of the shale.

\section{CENTRAL TEXAS (TRACT 13, MAP 2)}

Vine and Tourtelot (1970) studied three black shales in Texas, the Devonian and Mississippian Houy Formation and the Cretaceous Eagle Ford Shale and Buda Limestone. West of the Eagle Ford Shale, the Buda Limestone, in large part, has a very sinuous and sometimes sporadically distributed outcrop pattern. The Houy Formation crops out only in a small area in central Texas. Parts of the Eagle Ford Shale and most of the Buda Limestone are limestone according to geologic map descriptions; the extent of the black shale within the units is likely much smaller than the areas shown.

\section{IDAHO SHALE BELT (TRACT 14, MAP 2)}

The black-shale mineral belt of central Idaho encompasses nearly the entire Paleozoic section. Numerous 
formations contain thin carbonaceous shale beds, many of which contain mineral deposits. Some of the mineral deposits formed syngenetically, whereas others are epigenetic. These strata include both unmetamorphosed shale and phyllitic shale. It was not practical to distinguish the two at the scale of map 2 .

\section{CALIFORNIA COAST RANGES (TRACT 17, MAP 2)}

Numerous marine shales of Cretaceous through Tertiary age are found in the California Coast Ranges along with ophiolite sequences, melange, and other rock types. One of the more extensive marine shales is in the Miocene Monterey Formation, which has been investigated for uranium resources. Analysis of six samples from the Monterey Formation failed to detect PGE above the limits of analytical determination ( $2 \mathrm{ppb}$ for $\mathrm{Pt}, \mathrm{Pd}$, and $\mathrm{Rh} ; 1 \mathrm{ppb}$ for Ru and Ir). On map 2, the Monterey Formation is included in the Miocene marine beds.

\section{KLAMATH MOUNTAINS (TRACT 18, MAP 2)}

In the Klamath Mountains of southwestern Oregon is the Jurassic Galice Formation composed primarily of shale, some of which contains organic material. The Galice Formation is part of one of the several accreted terranes that make up the Klamath Mountains, which suggests that other accreted terranes might have organic-carbon-rich shales permissive for the accumulation of PGE.

\section{APACHE GROUP (TRACT 19, MAP 2)}

The upper part of the Dripping Spring Quartzite within the Apache Group contains uraniferous carbonaceous siltstone known to host chalcopyrite, pyrrhotite, pyrite, molybdenite, and galena as well as uranium-bearing minerals (Nutt, 1981). Although remobilized during metamorphism associated with widespread diabase intrusion, the uranium is thought to have been concentrated and deposited initially during diagenesis.

\section{ATLANTIC AND GULF COASTAL PLAINS (TRACT 20, MAP 2)}

Upper Cretaceous rocks along the Atlantic and Gulf coastal plains locally contain black shale units in a similar stratigraphic position as the Eagle Ford Shale of Texas. These black shales have not been discussed in the context of metal concentrations but were included here to provide continuity with the black shales of Texas and to indicate that it might be worthwhile to analyze these shales to see whether or not they have been mineralized.

\section{UNCONFORMITY URANIUM-GOLD TRACTS (FIG. 2)}

The U.S. does not have any known unconformity uranium-gold deposits of the type found in Saskatchewan and Australia. However, there are numerous areas scattered throughout the U.S. of Proterozoic rocks at unconformities. Kalliokoski and others (1978) developed a model for known deposits, which is similar to that of Grauch and Mosier (1986). Kalliokoski and others (1978) compared areas of Proterozoic rocks within the conterminous U.S. to their model and categorized them as having a high, medium, or low degree of similarity to the model. Figure 2 shows those areas which obtained a "high" rank (table 1) in that study. The unconformities themselves are much more restricted than the areas depicted on the figure. The interpretations of Nutt and others (1986) that structural controls are perhaps more important than unconformities and the importance of redox reactions below redbed sequences (Hoeve and Quirt, 1989) might lessen the favorability of some of these areas.

\section{QUARTZ-PEBBLE CONGLOMERATE GOLD-URANIUM TRACTS (MAP 1, PL. 1)}

Proterozoic quartz-pebble conglomerates that could host detrital concentrations of uraninite, pyrite, gold, and PGE are widespread in the U.S. but relatively small; most of the eight areas outlined on map 1 show the larger sedimentary units within which the generally thin and fairly limited quartz-pebble conglomerates are found. These conglomerates have received the greatest scrutiny in terms of their uranium potential (Houston and Karlstrom, 1979) and most have not been studied in detail for gold or PGE. Gold was analyzed for but not found in the Middle Proterozoic conglomerates of the Apache Group in Arizona (C.T. Wrucke, oral commun., 1991). However, the analyses have high detection limits, which would not have detected small gold concentrations. Nevertheless, the Apache Group rocks have not been given the status of a quartz-pebble conglomerate tract because of their young age. Fossil placers have not been mined in any of the areas except for minor amounts in the Black Hills, and geochemical data are generally lacking. The tracts are delineated because of the presence and recovery as a byproduct of PGE in the Witwatersrand of South Africa (Feather, 1976). However, comparison of possible U.S. fossil placer areas to the Witwatersrand may not be warranted because of the enormous size of the Witwatersrand compared to the known quartz-pebble conglomerates in the U.S. and because provenance is critical to the formation of placer PGE, and in some cases the potential source terranes are unknown. Fossil placers of other ages may have been preserved, but I did not undertake a comprehensive search to 


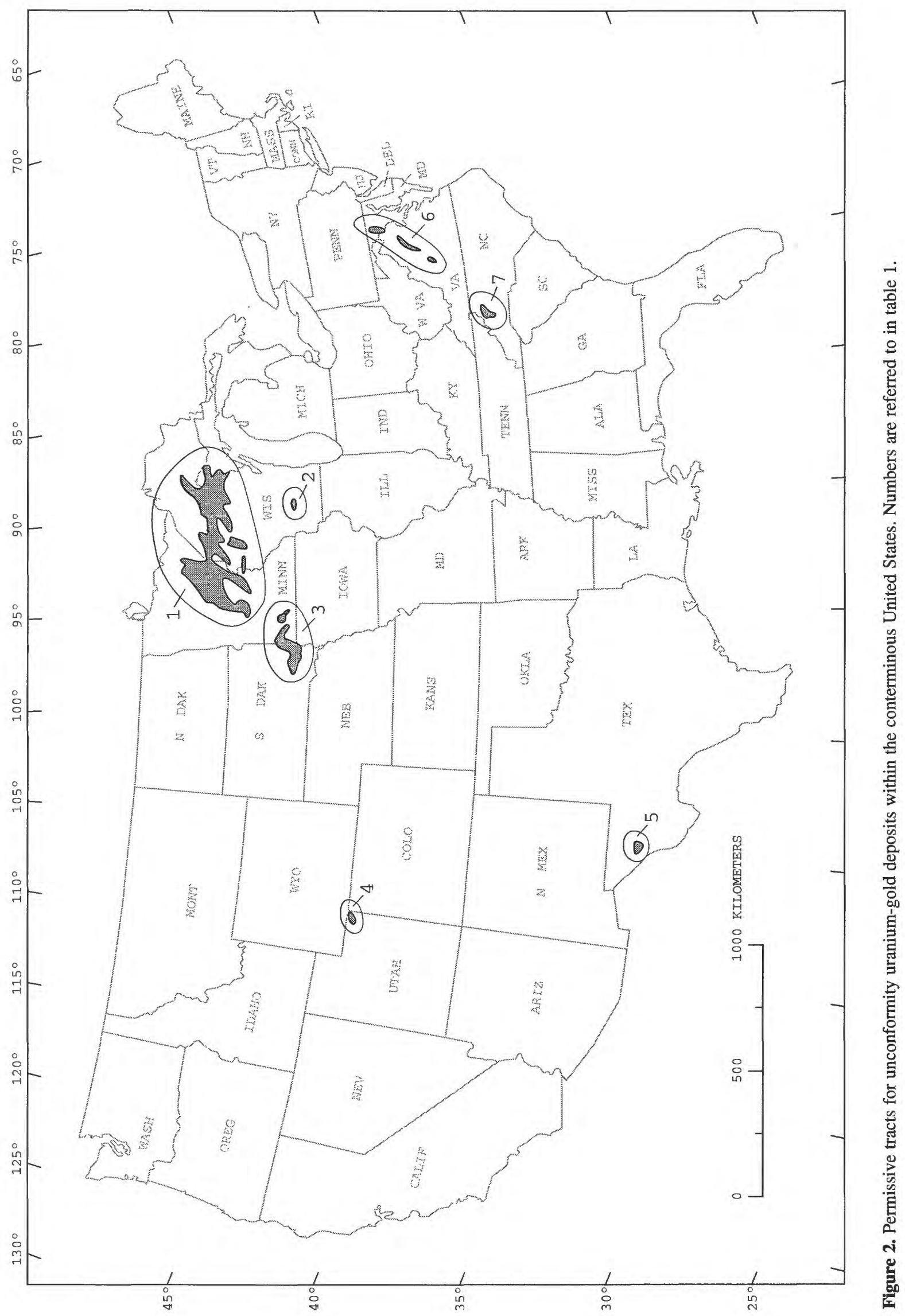


find all possible fossil placers because it is likely that most would be small and of little economic significance, except for the Tertiary deposits of California discussed in the placer section above.

\section{WYOMING (TRACT 15, MAP 1)}

The Sierra Madre and Medicine Bow Mountains of southeastern Wyoming are perhaps the best known of the quartz-pebble conglomerate areas within the U.S. The tracts show the metasedimentary Deep Lake Group and Phantom Lake Metamorphic Suite (Karlstrom and Houston, 1979), both of which contain quartz-pebble conglomerate. Some of the conglomerates have above-background radioactivity.

\section{BLACK HILLS (TRACT 16, MAP 1)}

The Nemo and the Bear Mountain Dome areas in the Black Hills of South Dakota have quartz-pebble conglomerates in the Boxelder Creek Formation, Estes Formation, and other similar rocks (Hills, 1979; DeWitt and others, 1986). Uranium has not been found in conglomerates of the Estes Formation as originally thought. Although these conglomerates are in a productive gold region (Homestake Mine), only small amounts of gold have been mined from them.

\section{MICHIGAN (TRACT 17, MAP 1)}

The tract outlines the latest Archean Dickinson Group, near the Wisconsin border in the Upper Peninsula of Michigan, which contains quartz-pebble conglomerates. These rocks are older than those generally known to contain uranium mineralization (Houston and Karlstrom, 1979), but they are permissive for other detrital material such as gold and PGE.

\section{MINNESOTA (TRACT 18, MAP 1)}

The lower units of the Proterozoic Animikie Group of east-central Minnesota contain quartz-pebble conglomerates below iron formation-bearing strata. The conglomerates may be too young for uranium mineralization but may contain other detrital material.

\section{MONTANA (TRACT 19, MAP 1)}

The southwest corner of Montana and small areas extending into Idaho have several Proterozoic units (table 1) that contain minor quartz-pebble conglomerate beds or metamorphosed equivalents. These areas may be more favorable for gold and PGE than for uranium mineralization because the units are possibly too young to contain detrital uranium minerals and pyrite (Anderson and others, 1987).

\section{SOUTHERN IDAHO (TRACT 20, MAP 1)}

A small part of southern Idaho and northern Utah in the Raft River Range area contains exposures of the Elba Quartzite, which may be too young to host uranium deposits (Houston and Karlstrom, 1979) but remains permissive for gold and PGE.

\section{SALT LAKE REGION (TRACT 21, MAP 1)}

Highly deformed Archean and Early Proterozoic metasedimentary rocks of the Farmington Canyon Complex crop out in the Wasatch Range and on Antelope Island in the Great Salt Lake. Quartz-pebble conglomerates are present in the complex.

\section{UINTA MOUNTAINS (TRACT 22, MAP 1)}

The Late Archean Red Creek Quartzite, exposed in the Uinta Mountains, contains beds of quartz-pebble conglomerate.

\section{BLACKBIRD COBALT-COPPER TRACT (TRACT 23, MAP 1)}

The Yellowjacket Formation of Proterozoic age, which correlates with the older formations within the Belt Supergroup, is widespread in central Idaho and southwestern Montana. Only a small part of the formation in the area of the Blackbird Mine is known to contain mineral deposits like that at the Blackbird Mine (map 1, deposit h). Most of the mineral occurrences in this area are in the middle unit (Unit B of Hughes, 1983) of the Yellowjacket Formation, and the area has been designated as permissive for Blackbird cobaltcopper deposits. This may be a unique area because of the presence of volcaniclastic rocks and gabbroic sills, and similar deposits are probably not present elsewhere in the Yellowjacket Formation. However, the similar Sheep Creek deposit in the Belt Basin (tract 8, map 1) implies that the Belt Supergroup (part of which is shown as a sediment-hosted copper tract) is also permissive for Blackbird-type deposits.

\section{SOUTHEAST MISSOURI LEAD-ZINC TRACT (TRACT 22, MAP 2)}

The small areas encompassing the Viburnum Trend and Fredericktown in southeastern Missouri are designated as permissive for PGE mineralization because of the com- 
mon presence of cobalt-nickel minerals. A small amount of platinum was detected in a sample from the region (see model above). Other areas of Mississippi Valley-type deposits are also reported to contain cobalt and nickel in cobalt-nickel and nickel minerals but in quantities too small for any economic interest.

\section{SOLUTION-COLLAPSE BRECCIA PIPE URANIUM TRACT (TRACT 23, MAP 2)}

The area outlined for solution-collapse breccia pipes includes all exposures of Mississippian Redwall Limestone through Triassic Chinle Formation where the Redwall Limestone is exposed or present in the subsurface (McKee and Gutschick, 1969). The major mineralized pipes are also shown on map 2. In well explored, sparsely vegetated areas the density of breccia pipes can exceed one per $13 \mathrm{~km}^{2}$, but most of the pipes are not mineralized. Pipes have not yet been found in all parts of the tracts, either because they are absent or because factors such as forest cover have prevented their identification.

\section{SUMMARY AND CONCLUSIONS}

This paper has provided a substantial amount of background material about the occurrence of PGE in a variety of sedimentary environments with which certain deposit types are associated. I used that material to outline tracts within the conterminous U.S. where such deposits have been or may be found. I identified tracts permissive for eight deposit types (also see coal section above), some of which contain deposits of the type in question and some of which do not but which have permissive characteristics. Thus far, there have been only a few analyses for PGE within these environments, most of which indicate the presence of PGE in the low parts per billion range. Although this may sound discouraging for future PGE exploration, most of the analyses have been for samples collected for other purposes and do not represent a thorough search for PGE. A more systematic approach to the search for PGE in these environments and sampling at what may be more favorable horizons within a sedimentary package could lead to the discovery of PGE in greater concentrations than have been found.

It was not my purpose to rank the favorability of given deposit types or of tracts within each deposit type, but some generalizations can be made as to PGE favorability. In light of current research and exploration interest and of knowledge about PGE in similar environments throughout the world, areas of metalliferous black shales and sediment-hosted copper deposits should be a major focus of PGE studies. Although placer deposits have been important historically, those in the U.S. are small by com- parison and the productive ones have generally had very low concentrations of PGE relative to gold. The geochemical characteristics of Blackbird cobalt-copper, southeast Missouri lead-zinc, and sollution-collapse breccia pipe uranium deposits make these environments interesting, but the known permissive areas are rather small relative to black shales and sediment-hosted copper tracts and the few PGE data available are not overly encouraging. Because unconformity uranium-gold and quartz-pebble conglomerate gold-uranium tracts are not even known to contain deposits of those types and because they are so small, these areas are of little interest currently, but future geochemical data or mineral deposit information may alter this conclusion, and the areas should not yet be ignored.

\section{SELECTED REFERENCES}

Alabama Geological Survey, 1926, Geologic map of Alabama: Alabama Geological Survey in cooperation with the U.S. Geological Survey, scale 1:500,000.

Allen, R.C., Smith, R.A., and Barrett, L.P., 1916, Geological map of Michigan: Michigan Geological and Biological Survey Publication 23, scale 1:750,000.

Anderson, J.R., Goodknight, C.S., Sewell, J.M., and Riley, J.K., 1987, Favorability of Precambrian quartz-pebble conglomerates in the United States as uranium hosts, in Uranium deposits in Proterozoic quartz-pebble conglomerates: Vienna, Austria, International Atomic Energy Agency, p. 7-40.

Annels, A.E., 1974, Some aspects of the stratiform ore deposits of the Zambian Copperbelt and their genetic significance, in Bartholomé, Paul, ed., Gisements stratiformes et provinces cupriferes: Société Geologique de Belgique, p. 235-254.

Annels, A.E., Vaughan, D.J., and Craig, J.R., 1983, Conditions of ore mineral formation in certain Zambian Copperbelt deposits with special reference to the role of cobalt: Mineralium Deposita, v. 18, p. 71-88.

Banas, Marian, 1980, Zechstein copper deposits in Poland, in Jankovic, S., and Sillitoe, R.H., eds., European copper deposits, Proceedings of an international symposium held at Bor, Yugoslavia, 18-22 Sept. 1979: Society for Geology Applied to Mineral Deposits Special Publication No. 1, p. 136145.

Barnes, V.E., Project director, 1966, Geologic atlas of Texas, Texarcana sheet: Bureau of Economic Geology, The University of Texas at Austin, scale 1:250,000.

1967 , Geologic atlas of Texas, Sherman sheet: Bureau of Economic Geology, The University of Texas at Austin, scale $1: 250,000$.

1970, Geologic atlas of Texas, Waco sheet: Bureau of Economic Geology, The University of Texas at Austin, scale $1: 250,000$.

1972, Geologic atlas of Texas, Dallas sheet: Bureau of Economic Geology, The University of Texas at Austin, scale $1: 250,000$.

1974a, Geologic atlas of Texas, Austin sheet: Bureau of Economic Geology, The University of Texas at Austin, scale $1: 250,000$. 
Barnes, V.E. Project director, 1974b, Geologic atlas of Texas, San Antonio sheet: Bureau of Economic Geology, The University of Texas at Austin, scale 1:250,000.

-1974c, Geologic atlas of Texas, Seguin sheet: Bureau of Economic Geology, The University of Texas at Austin, scale $1: 250,000$.

1975, Geologic atlas of Texas, San Angelo sheet: Bureau of Economic Geology, The University of Texas at Austin, scale $1: 250,000$.

1976a, Geologic atlas of Texas, Brownwood sheet: Bureau of Economic Geology, The University of Texas at Austin, scale $1: 250,000$.

1976b, Geologic atlas of Texas, Pecos sheet: Bureau of Economic Geology, The University of Texas at Austin, scale $1: 250,000$.

1977, Geologic atlas of Texas, Del Rio sheet: Bureau of Economic Geology, The University of Texas at Austin, scale $1: 250,000$.

1979a, Geologic atlas of Texas, Emory Peak-Presidio sheet: Bureau of Economic Geology, The University of Texas at Austin, scale 1:250,000.

1979b, Geologic atlas of Texas, Marfa sheet: Bureau of Economic Geology, The University of Texas at Austin, scale $1: 250,000$.

1981a, Geologic atlas of Texas, Llano sheet: Bureau of Economic Geology, The University of Texas at Austin, scale $1: 250,000$.

-1981b, Geologic atlas of Texas, Sonora sheet: Bureau of Economic Geology, The University of Texas at Austin, scale $1: 250,000$.

1982, Geologic atlas of Texas, Fort Stockton sheet: Bureau of Economic Geology, The University of Texas at Austin, scale $1: 250,000$.

1983, Geologic atlas of Texas, Van Horn-El Paso sheet: Bureau of Economic Geology, The University of Texas at Austin, scale 1:250,000.

Bartholomé, P., Evard, P., Katekesha, F., Lopez-Ruiz, J., and Ngongo, M., 1973, Diagenetic ore-forming processes at Kamoto Katanga, Republic of the Congo, in Amstutz, G.C., and Bernard, A.J., eds., Ores in sediments: New York, SpringerVerlag, p. 21-41.

Bateman, A.M., 1923, Primary chalcocite: Bristol copper mine, Connecticut: Economic Geology, v. 18, p. 122-166.

Bell, R.T., 1978, Uranium in black shales-a review, in Kimberley, M.M., ed., Short course in uranium deposits: their mineralogy and origin: Mineralogical Association of Canada Short Course Handbook, v. 3, p. 307-329.

Bennett, E.H., 1977, Reconnaissance geology and geochemistry of the Blackbird Mountain-Panther Creek region, Lemhi County, Idaho: Idaho Bureau of Mines and Geology Pamphlet $167,108 \mathrm{p}$.

Berg, T.M., chief compiler, and others, 1980, Geologic map of Pennsylvania: Pennsylvania Bureau of Topographic and Geologic Survey, scale 1:250,000.

Berry, W.B.N., and Wilde, Pat, 1978, Progressive ventilation of the oceans-an explanation for the distribution of the lower Paleozoic black shales: American Journal of Science, v. 278, p. 257-275.

Bicker, A.R., Jr., compiler, 1969, Geologic map of Mississippi: Mississippi Geological Survey, scale 1:500,000.
Blair, W.N., Page, N.J, and Johnson, M.G., 1977, Map and list of reported occurrences of platinum-group metals in the conterminous United States: U.S. Geological Survey Miscellaneous Field Studies Map MF-861, scale 1:5,000,000.

Bliss, J.D., ed., 1992, Developments in mineral deposit modeling: U.S. Geological Survey Bulletin 2004, 168 p.

Bliss, J.D., Orris, G.J., and Menzie, W.D., 1987, Changes in grade, volume and contained gold during the mining life-cycle of gold placer deposits: Canadian Institute of Mining Bulletin, v. 80 , no. 903 , p. $75-80$.

Block, Chantal, and Dams, Richard, 1975, Inorganic composition of Belgian coals and coal ashes: Environmental Science and Technology, v. 9, no. 2, p. 146-150.

Borg, G., Tredoux, M., Maiden, K.J., Sellschop, J.P.F., and Wayward, O.D.F., 1988, PGE- and Au-distribution of rift-related volcanics, sediments, and stratabound $\mathrm{Cu} / \mathrm{Ag}$ ores of Middle Proterozoic age in central SWA/Namibia, in Prichard, H.H., Potts, P.J., Bowles, J.F.W., and Cribb, S.J., eds., Proceedings of the symposium Geo-Platinum 87 held at the Open University, Milton-Keynes, Great Britain, April 22-23, 1987, Basking, Essex, Great Britain, Elsevier, p. 303-317.

Bornhorst, T.J., Rose, W.I., Jr., and Paces, J.B., 1983, Field guide to the geology of the Keweenaw Peninsula, Michigan: 29th Annual Institute on Lake Superior Geology, Houghton, Michigan Technological University, $116 \mathrm{p}$.

Bownocker, J.A., 1947, Geologic map of Ohio: Geological Survey of Ohio, scale 1:500,000.

Boyle, R.W., 1979, The geochemistry of gold and its deposits: Geological Survey of Canada Bulletin 280, p. 310-333.

Boyle, R.W., Brown, A.C., Jefferson, C.W., Jowett, E.C., and Kirkham, R.V., eds., 1989, Sediment-hosted stratiform copper deposits: Geological Association of Canada Special Paper 36, $710 \mathrm{p}$.

Bradley, W.W., 1921, Platinum, in California mineral production for 1920: California Division of Mines and Geology Bulletin 90 , p. 68-69.

Breit, G.N., Meunier, J.D., Rowan, E.L., and Goldhaber, M.B., 1987, Alteration related to red bed copper mineralizing brines and other fault-controlled solutions in Lisbon Valley, Utah, and the Slick Rock district, Colorado: U.S. Geological Survey Circular 995, p. 7-8.

Briskey, J.A., 1986, Descriptive model of southeast Missouri $\mathrm{Pb}-\mathrm{Zn}$, in Cox, D.P., and Singer, D.A., eds., Mineral deposit models: U.S. Geological Survey Bulletin 1693, p. 220221.

Brown, A.C., 1971, Zoning in the White Pine copper deposit, Ontonagon County, Michigan: Economic Geology, v. 66, p. 543-573.

1986, Marquette district, lower Proterozoic copper and iron, in Brown, A.C., and Kirkham, R.V., eds., Field trip 1 Guidebook, Proterozoic sediment-hosted stratiform copper deposits of Upper Michigan and Belt Supergroup of Idaho and Montana: Geological Association of Canada, 72 p.

Brown, A.C., and Chartrand, F.M., 1986, Diagenetic features at White Pine (Michigan), Redstone (N.W. Territories, Canada) and Kamoto (Zaire). Sequence of mineralization in sediment-hosted copper deposits (Part 1), in Friedrich, G.H., Genkin, A.D., Naldrett, A.J., Ridge, J.D., Sillitoe, R.H., and Vokes, F.M., eds., Geology and metallogeny of copper deposits: New York, Springer-Verlag, p. 390-411. 
Buchanan, D.L., 1988, Platinum-group element exploration: Developments in Economic Geology, v. 26, New York, Elsevier, $185 \mathrm{p}$.

Burchett, R.R., 1986, Geologic bedrock map of Nebraska: Nebraska Geological Survey, scale 1:1,000,000.

Burger, A.M., Forsyth, J.L., Nicoll, R.S., and Wayne, W.J., 1971, Geologic map of the $1^{\circ} \times 2^{\circ}$ Munice quadrangle, Indiana and Ohio, showing bedrock and unconsolidated deposits: Indiana Geological Survey, Regional Geologic Map No. 5, scale $1: 250,000$.

Burnett, J.L., and Jennings, C.W., 1962, Geologic map of California, Chico sheet: California Division of Mines and Geology, scale 1:250,000.

Cabri, L.J., 1981, The platinum-group minerals, in Cabri, L.J., ed., Platinum-group elements: mineralogy, geology, recovery: Canadian Institute of Mining and Metallurgy Special Volume 23, p. 83-150.

Cabri, L.J., and Harris, D.C., 1975, Zoning in Os-Ir alloys and the relation of the geological and tectonic environment of the source rocks to the bulk $\mathrm{Pt}: \mathrm{Pt}+\mathrm{Ir}+\mathrm{Os}$ ratio for placers: Canadian Mineralogist, v. 13, p. 266-274.

Cabri, L.J., and Laflamme, J.H.G., 1981, Analyses of minerals containing platinum-group elements, in Cabri, L.J., ed., Platinum-group elements: mineralogy, geology, recovery: Canadian Institute of Mining and Metallurgy Special Volume 23, p. $151-173$.

Calver, J.L., Hobbs, C.R.B., Jr., Milici, R.C., Spiker, C.T., Jr., and Wilson, J.M., eds., 1963, Geologic map of Virginia: Virginia Division of Mineral Resources, scale 1:500,000.

Cardwell, D.H., Erwin, R.B., Woodward, H.P., and Lotz, C.W., 1968, Geologic map of West Virginia: West Virginia Geological and Economic Survey, scale 1:250,000, 2 sheets.

Carlson, C.A., Wilson, S.A., Carlson, R.R., Bradley, L.A., Cornell, J., Gent, C.A., Gross, W.D., Groeneboer, H., Haffty, J., Haubert, A.W., Love, A.H., McDade, J.M., Moore, R.F., Riley, L.B., Moring, B.C., Singer, D.A., and Page, N.J, 1985, Analyses for platinum-group elements in samples from podiform chromite deposits, California and Oregon: U.S. Geological Survey Open-File Report 85-442, 14 p.

Chyi, L.L., 1982, The distribution of gold and platinum in bituminous coal: Economic Geology, v. 77, p. 1592-1597.

Clayton, Lee, 1980, Geologic map of North Dakota: North Dakota Geological Survey, scale 1:500,000.

Cleaves, E.T., Edwards, Jonathan, Jr., and Glaser, J.D., 1968, Geologic map of Maryland: Maryland Geological Survey, scale $1: 250,000$.

Clemmy, H., 1974, Sedimentary geology of a Late Precambrian copper deposit at Kitwe, Zambia, in Bartholomé, Paul, ed., Gisements stratiformes et provinces cupriferes: Société Geologique de Belgique, p. 255-265.

Conant, L.C., and Swanson, V.E., 1961, Chattanooga Shale and related rocks of central Tennessee and nearby areas: U.S. Geological Survey Professional Paper 357, 91 p.

Constenius, K.N., and Dyni, J.R., 1983, Lacustrine oil shales and stratigraphy of part of the Kishenehn Basin, northwestern Montana: Mineral and Energy Resources, v. 26, no. 4, p. 116.

Cooke, C.W., 1936, Geology of the coastal plain of South Carolina: U.S. Geological Survey Bulletin 867, p. 25-32, pl. 2, scale $1: 500,000$.
Coombes, J.S., 1990, Platinum 1990: London, Johnson Matthey Public Limited Company, 64 p.

Cousins, C.A., 1973, Platinoids in the Witwatersrand system: Journal of the South African Institute of Mining and Metallurgy, v. 73, p. 184-199.

Cousins, C.A., and Vermaak, C.F., 1976, The contribution of southern African ore deposits to the geochemistry of platinum-group metals: Economic Geology, v. 71, p. 287-305.

Coveny, R.M., Jr., and Glascock, M.D., 1989, A review of the origins of metal-rich Pennsylvanian black shales, central U.S.A., with an inferred role for basinal brines: Applied Geochemistry, v. 4, p. 347-367.

Coveny, R.M., Jr., Levanthal, J.S., Glascock, M.D., and Match, J.R., 1987, Origins of metals and organic matter in the Mecca Quarry Shale Member and stratigraphically equivalent beds across the Midwest: Economic Geology, v. 82, p. 915-933.

Coveny, R.M., Jr., and Chen, Nansheng, 1990, Nickel-molybdenum-platinum-gold deposits in black shales of southern China-a new ore type with possible analogs in Pennsylvanian rocks of the U.S.A., in Grauch, R.I., and Huyck, H.L.O., eds., Metalliferous black shales and related ore depositsProceedings, 1989 United States Working Group Meeting, International Geological Correlation Program Project 254: U.S. Geological Survey Circular 1058, p. 9-11.

Cox, D.P., 1986a, Descriptive model of quartz pebble conglomerate $\mathrm{Au}-\mathrm{U}$, in Cox, D.P., and Singer, D.A., eds., Mineral deposit models: U.S. Geological Survey Bulletin 1693, p. 199. 1986b, Descriptive model of sediment-hosted $\mathrm{Cu}$, in Cox, D.P., and Singer, D.A., eds., Mineral deposit models: U.S. Geological Survey Bulletin 1693, p. 205.

Cox, D.P., and Singer, D.A., eds., 1986, Mineral deposit models: U.S. Geological Survey Bulletin 1693, 379 p.

Cressman, E.R., 1985, The Prichard Formation of the lower part of the Belt Supergroup (Middle Proterozoic), near Plains, Sanders County, Montana: U.S. Geological Survey Bulletin $1553,64 \mathrm{p}$.

Crocket, J.H., 1981, Geochemistry of the platinum-group elements, in Cabri, L.J., ed., Platinum-group elements: mineralogy, geology, recovery: Canadian Institute of Mining and Metallurgy Special Volume 23, p. 47-64.

Crocket, J.H., Macdougall, J.D., and Harriss, R.C., 1973, Gold, palladium and iridium in marine sediments: Geochimica et Cosmochimica Acta, v. 37, p. 2547-2556.

Dane, C.H., and Bachman, G.O., 1965, Geologic map of New Mexico: U.S. Geological Survey, scale 1:500,000.

Darton, N.H., 1951, Geologic map of South Dakota: U.S. Geological Survey, scale 1:500,000.

Darton, N.H., Stephenson, L.W., and Gardner, Julia, 1937, Geologic map of Texas: U.S. Geological Survey, scale 1:500,000.

De Magnée, I., and Francois, A., 1988, The origin of the Kipushi $(\mathrm{Cu}, \mathrm{Zn}, \mathrm{Pb})$ deposit in direct relation with a Proterozoic salt diapir. Copperbelt of central Africa, Shaba, Republic of Zaire in Friedrich, G.H., and Herzig, P.M., eds., Base metal sulfide deposits in sedimentary and volcanic environments: Society for Geology Applied to Mineral Deposits Special Publication 5, p. 74-93.

Derkey, P.D., Abercrombie, F.N., Vuke, S.M., and Daniel, J.A., 1985, Geology and oil shale resources of the Heath Formation, Fergus County, Montana: Montana Bureau of Mines and Geology Memoir 57, 100 p. 
Desborough, G.A., Hatch, J.R., and Leventhal, J.S., 1990, Geochemical and mineralogical comparison of the Upper Pennsylvanian Stark Shale member of the Dennis Limestone, east-central Kansas, with the Middle Pennsylvanian Mecca Quarry Shale member of the Carbondale Formation in Illinois and of the Linton Formation in Indiana, in Grauch, R.I., and Huyck, H.L.O., eds., Metalliferous black shales and related ore deposits-Proceedings, 1989 United States Working Group Meeting, International Geological Correlation Program Project 254: U.S. Geological Survey Circular 1958, p. 12-30.

Desborough, G.A., and Poole, F.G., 1983, Metal concentrations in some marine black shales of the United States, in Shanks, W.C., III, ed., Cameron volume on unconventional mineral deposits: New York, American Institute of Mining, Metallurgical, and Petroleum Engineers, Inc., p. 99-110.

Desborough, G.A., Poole, F.G., Hose, R.K., and Radtke, A.S., 1979, Metals in Devonian kerogenous marine strata at Gibellini and Bisoni properties in southern Fish Creek Range, Eureka County, Nevada: U.S. Geological Survey Open-File Report 79-530, 31 p.

DeWitt, Ed, Redden, J.A., Wilson, A.B., and Buscher, David, 1986, Mineral resource potential and geology of the Black Hills National Forest, South Dakota and Wyoming: U.S. Geological Survey Bulletin 1580, p. 58-66.

Donnell, J.R., 1976, Environments of deposition of oil shale [abs.]: American Association of Petroleum Geologists Bulletin, v. 60 , p. 666.

Durham, D.L., 1987, Uranium in the Monterey Formation of California: U.S. Geological Survey Bulletin 1581-A, 29 p.

Dunn, C.E., 1986, Biogeochemistry as an aid to exploration for gold, platinum and palladium in the northern forests of Saskatchewan, Canada: Journal of Geochemical Exploration, v. 25 , p. $21-40$.

Earhart, R.L., 1986, Descriptive model of Blackbird $\mathrm{Co}-\mathrm{Cu}$, in Cox, D.P., and Singer, D.A., eds., Mineral deposit models: U.S. Geological Survey Bulletin 1693, p. 142.

Emmons, W.H., and Calkins, F.C., 1913, Geology and ore deposits of the Philipsburg quadrangle, Montana: U.S. Geological Survey Professional Paper 78, 271 p.

Ensign, C.O., Jr., White, W.S., Wright, J.C., Patrick, J.L., Leone, R.J., Hathaway, D.J., Trammell, J.W., Fritts, J.J., and Wright, T.L., 1968, Copper deposits in the Nonesuch Shale, White Pine, Michigan, in Ridge, J.D., ed., Ore deposits in the United States 1933/1967, Graton-Sales Volume I: American Institute of Mining, Metallurgical, and Petroleum Engineers, p. $460-488$.

Feather, C.E., 1976, Mineralogy of platinum-group minerals in the Witwatersrand, South Africa: Economic Geology, v. 71, p. $1399-1428$.

Feather, C.E., and Koen, G.M., 1975, The mineralogy of the Witwatersrand reefs: Minerals Science and Engineering, v. 7, no. 3, p. 189-224.

Finch, W.I., 1992, Descriptive model of solution-collapse breccia pipe uranium deposits, in Bliss, J.D., ed., Developments in mineral deposit modeling: U.S. Geological Survey Bulletin 2004, p. 33-35.

Finch, W.I., Pierson, C.T., and Sutphin, H.B., 1992, Grade and tonnage model of solution-collapse breccia pipe uranium deposits, in Bliss, J.D., ed., Developments in mineral deposit modeling: U.S. Geological Survey Bulletin 2004, p. 36-38.
Finkelman, R.B., 1981, Modes of occurrence of trace elements in coal: U.S. Geological Survey Open-File Report 81-99, $322 \mathrm{p}$.

Finkelman, R.B., and Aruscavage, P.J., 1981, Concentration of some platinum-group metals in coal: International Journal of Coal Geology, v. 1, p. 95-99.

Finkelman, R.B., and Brown, R.D., 1988, Mineral resources and geochemical exploration potential of coal that has anomalous metal concentrations [abs.], in Schindler, K.S., ed., USGS research on mineral resources-1989, program and abstracts: U.S. Geological Survey Circular 1035, p. 18-19.

Fisher, D.W., Isachen, Y.W., and Rickard, L.V., 1970, Geologic map of New York, Hudson-Mohawk sheet: New York State Museum and Science Service Map and Chart Series No. 15, scale $1: 250,000$.

1979, Geologic map of New York, Lower Hudson sheet: New York State Museum and Science Service Map and Chart Series No. 15, scale 1;250,000.

Fix, C.E., 1958, Selected annotated bibliography of the geology and occurrence of uranium-bearing marine black shales in the United States: U.S. Geological Survey Bulletin 1059-F, p. 263-325.

Froelich, A.J., and Leavy, B.D., 1982, Map showing mineral resources of the Culpeper Basin, Virginia and Maryland: availability and planning for future needs: U.S. Geological Survey Miscellaneous Geologic Investigations Map I-1313B, scale 1:125,000.

Gair, J.E., and Thaden, R.E., 1968, Geology of the Marquette and Sands quadrangles, Marquette County, Michigan: U.S. Geological Survey Professional Paper 397, 77 p.

Gillette, Tracy, 1947, The Clinton of western and central New York: New York State Museum Bulletin 341, 191 p.

Gilmore, J.S., Knight, J.D., Orth, C.J., Pillmore, C.L., and Tschudy, R.H., 1984, Trace element patterns at a non-marine Cretaceous-Tertiary boundary: Nature, v. 307, no. 5948, p. 224-228.

Goldschmidt, V.M., 1954, Geochemistry: London, Oxford Press, $730 \mathrm{p}$.

Goldschmidt, V.M., and Peters, C.L., 1933, Über die anreicherung seltener Elemente in Steinkohlen: Nachrichte Gesellschaft Wissenschaft Gottingen, Math.-Physik, Klasse, Heft 4, p. 371386.

Gornitz, Vivien, and Kerr, P.F., 1970, Uranium mineralization and alteration, Orphan Mine, Grand Canyon, Arizona: Economic Geology, v. 65, p. 751-768.

Graf, Paul, 1979, A review of the stratigraphy and uranium potential of Early Proterozoic (Precambrian X) metasediments in the Sierra Madre, Wyoming: Contributions to Geology, University of Wyoming, v. 17, no. 2, p. 149-157.

Granger, H.C., and Raup, R.B., Jr., 1964, Stratigraphy of the Dripping Spring Quartzite, southeastern Arizona: U.S. Geological Survey Bulletin 1168, 119 p.

Grauch, R.I., 1989, Early-Middle Proterozoic unconformities: unconventional sources for platinum group and precious metals [abs.], in Schindler, K.S., ed., USGS research on mineral resources-1989, program and abstracts: U.S. Geological Survey Circular 1035, p. 26.

Grauch, R.I., Coveney, R.M., Jr., Murowchick, J.B., and Chen, Nansheng, 1991, Black shales as hosts for unconventional platinum-group-element resources? Examples from southern 
China and the Yukon, Canada, and implications for U.S. resources [abs.], in Good, E.E., Slack, J.F., and Kotra, R.K., eds., USGS research on mineral resources-1991, program and abstracts: U.S. Geological Survey Circular 1062, p. 33.

Grauch, R.I., and Mosier, D.L., 1986, Descriptive model of unconformity U-Au, in Cox, D.P., and Singer, D.A., eds., Mineral deposit models: U.S. Geological Survey Bulletin 1693, p. 248-249.

Grauch, R.I., Nutt, C.J., and McAleese, I., 1985, Observations on the distribution of uranium at the Jabiluka 1 and 2 deposits; Northern Territory, Australia, in Sibbald, T.I.I., and Petruk, W., eds., Geology of uranium deposits: Canadian Institute of Mining and Metallurgy Special Volume 32, p. 263.

Gray, H.H., 1972, Geologic map of the $1^{\circ} \times 2^{\circ}$ Louisville quadrangle, Indiana, showing bedrock and unconsolidated deposits: Indiana Geological Survey, Regional Geologic Map No. 6 , scale $1: 250,000$.

Gray, H.H., Bleuer, N.K., Hill, J.R., and Lineback, J.A., 1979, Geologic map of the $1^{\circ} \times 2^{\circ}$ Indianapolis quadrangle, Indiana and Illinois, showing bedrock and unconsolidated deposits: Indiana Geological Survey, Regional Geologic Map No. 1, scale 1:250,000.

Gray, H.H., Forsyth, J.L., Schneider, A.F., and Gooding, A.M., 1972 , Geologic map of the $1^{\circ} \times 2^{\circ}$ Cincinnati quadrangle, Indiana and Ohio, showing bedrock and unconsolidated deposits: Indiana Geological Survey, Regional Geologic Map No. 7, scale 1:250,000.

Gray, H.H., Wayne, W.J., and Wier, C.E., 1970, Geologic map of the $1^{\circ} \times 2^{\circ}$ Vincennes quadrangle and parts of adjoining quadrangles, Indiana and Illinois, showing bedrock and unconsolidated deposits: Indiana Geological Survey, Regional Geologic Map No. 3, scale 1:250,000.

Gray, N.H., 1988, The origin of copper occurrences in the Hartford Basin, in Froelich, A.J., and Robinson, G.R., Jr., eds., Studies of the early Mesozoic basins of the eastern United States: U.S. Geological Survey Bulletin 1776, p. 341-349.

Guilbert, J.M., and Park, C.F., Jr., 1985, The geology of ore deposits: New York, W.H. Freeman and Company, p. 754-770.

Gustafson, L.B., and Williams, Neil, 1981, Sediment-hosted stratiform deposits of copper, lead, and zinc: Economic Geology 75th Anniversary Volume, p. 139-178.

Hahn, G.A., and Hughes, G.J., Jr., 1984, Sedimentation, tectonism, and associated magmatism of the Yellowjacket Formation in the Idaho cobalt belt, Lemhi County, Idaho, in Hobbs, S.W., ed., The Belt: Montana Bureau of Mines and Geology Special Publication 90, p. 65-67.

Haley, B.R., Glick, E.E., Bush, W.V., Clardy, B.F., Stone, C.G., Woodward, M.B., and Zachry, D.L., 1976, Geologic map of Arkansas: Arkansas Geological Survey and U.S. Geological Survey, scale 1:500,000.

Hall, W.E., 1985, Stratigraphy of and mineral deposits in middle and upper Paleozoic rocks of the black-shale mineral belt, central Idaho, in McIntyre, D.H., ed., Symposium on the geology and mineral deposits of the Challis $1^{\circ} \times 2^{\circ}$ quadrangle, Idaho: U.S. Geological Survey Bulletin 1658-J, p. 117-131.

Hall, W.E., and Hobbs, S.W., 1987, Black shale terrane, in Fisher, F.S., and Johnson, K.M., eds., Preliminary manuscript for "Mineral-resource potential and geology of the Challis $1^{\circ} \times 2^{\circ}$ quadrangle, Idaho": U.S. Geological Survey Open-File Report $87-480$, p. $29-42$.
Ham, W.E., and Johnson, K.S., 1964, Copper deposits in Permian shale, Creta area: Oklahoma Geological Survey Circular 64, $32 \mathrm{p}$.

Hamilton, S.K., 1967, Copper mineralization in the upper part of the Copper Harbor Conglomerate at White Pine, Michigan: Economic Geology, v. 62, p. 885-904.

Hardeman, W.D., Miller, R.A., and Swingle, G.D., 1966, Geologic map of Tennessee: Tennessee Division of Geology, scale $1: 250,000$.

Harrison, J.E., 1972, Precambrian Belt basin of northwest United States: its geometry, sedimentation, and copper occurrences: Geological Society of America Bulletin, v. 38, p. 1215-1240.

Hawley, J.E., and Rimsaite, Y., 1953, Platinum metals in some Canadian uranium and sulphide ores: American Mineralogist, v. 38, p. 463-475.

Hayes, T.S., 1985, A model for genesis of red-bed-evaporite-associated stratabound copper deposits and potential within the Springfield $1^{\circ} \times 2^{\circ}$ quadrangle, in Martin, J.A., and Pratt, W.P., eds., Geology and mineral resource potential of the Springfield $1^{\circ} \times 2^{\circ}$ quadrangle, Missouri, as appraised in September 1985: U.S. Geological Survey Open-File Report 85-42-MR, p. 61 -71.

Hayes, T.S., and Einaudi, M.T., 1986, Genesis of the Spar Lake stratabound copper-silver deposit, Montana: Part 1. Controls inherited from sedimentation and pre-ore diagenesis: Economic Geology, v. 81, p. 1899-1931.

Hayes, T.S., Rye, R.O., Whelan, J.F., and Landis, G.P., 1989, Geology and sulphur-isotope geothermometry of the Spar Lake stratabound $\mathrm{Cu}-\mathrm{Ag}$ deposit in the Belt Supergroup, Montana, in Boyle, R.W., Brown, A.C., Jefferson, C.W., Jowett, E.C., and Kirkham, R.V., eds., Sediment-hosted stratiform copper deposits: Geological Association of Canada Special Paper 36, p. 319-338.

Heyl, A.V., 1982, Mineral deposit occurrence model for the Viburnum Trend subregion of the southeast Missouri base metal and barite district, in Erickson, R.L., compiler, Characteristics of mineral deposit occurrences: U.S. Geological Survey Open-File Report 82-795, p. 158-171.

Hills, F.A., 1979, Uranium, thorium, and gold in lower Proterozoic(?) Estes Conglomerate, Nemo District, Lawrence County, South Dakota: Contributions to Geology, University of Wyoming, v. 17 , no. 2 , p. $159-172$.

1987, Tectonic environment of Precambrian quartz-pebble conglomerate uranium deposits formed along the southern margin of the Archean shield in North America, in Uranium deposits in quartz-pebble conglomerates: Vienna, Austria, International Atomic Energy Agency, p. 41-59.

Himes, M.D., and Petersen, E.U., 1990, Geological and mineralogical characteristics of the Sheep Creek copper-cobalt sediment-hosted stratabound sulfide deposit, Meagher County, Montana, in Hausen, D.M., Halbe, D.N., Petersen, E.U., and Tafuri, W.J., eds., Gold '90, Proceedings of the Gold '90 Symposium, Salt Lake City, Utah, February 26 to March 1, 1990: Littleton, Colo., Society for Mining, Metallurgy, and Exploration, Inc., p. 533-546.

Hintze, L.F., 1980, Geologic map of Utah: Utah Geological and Mineral Survey, scale 1:500,000.

Hoatson, D.M., and Glaser, L.M., 1989, Geology and economics of platinum-group metals in Australia: Australian Bureau of Mineral Resources, Geology \& Geophysics Resource Report $5,81 \mathrm{p}$. 
Hoeve, J., and Quirt, D., 1989, A common diagenetic-hydrothermal origin for unconformity-type uranium and stratiform copper deposits?, in Boyle, R.W., Brown, A.C., Jefferson, C.W., Jowett, E.C., and Kirkham, R.V., eds., Sediment-hosted stratiform copper deposits: Geological Association of Canada Special Paper 36, p. 151-172.

Hoeve, Jan, and Sibbald, T.I.I., 1978, On the genesis of Rabbit Lake and other unconformity-type uranium deposits in northern Saskatchewan, Canada: Economic Geology, v. 73, p. 1450-1473.

Houston, R.S., and Ebbett, B.E., 1977, Geologic map of the Sierra Madre and western Medicine Bow Mountains, southeastern Wyoming: U.S. Geological Survey Miscellaneous Field Studies Map MF-827, scale 1:125,000.

Houston, R.S., and Karlstrom, K.E., 1979, Uranium-bearing quartz-pebble conglomerates: exploration model and United States resource potential: Laramie, University of Wyoming, Prepared for the U.S. Department of Energy, 376 p.

1987, Application of the time and stratabound model for the origin of uranium-bearing quartz-pebble conglomerate in southeastern Wyoming, USA, in Uranium deposits in Proterozoic quartz-pebble conglomerates: Vienna, Austria, International Atomic Energy Agency, p. 99-131.

Houston, R.S., Karlstrom, K.E., and Graff, P.J., 1979, Progress report on the study of radioactive quartz-pebble conglomerate of the Medicine Bow Mountains and Sierra Madre, southeastern Wyoming: U.S. Geological Survey Open-File Report 79-1131, $43 \mathrm{p}$.

Hughes, G.J., Jr., 1983, Basinal setting of the Idaho cobalt belt, Blackbird mining district, Lemhi County, Idaho, in Proceedings of the Denver Region Exploration Geologists Society Symposium, The Genesis of Rocky Mountain Ore Deposits: Changes with Time and Tectonics: Denver, Colo., Denver Region Exploration Geologists Society, p. 21-27.

Hulbert, L., 1987, Geological environments for platinum group element mineralization-a brief overview, in Gilboy, C.F., and Vigrass, L.W., eds., Economic minerals of Saskatchewan: Saskatchewan Geological Society Special Publication 8, p. 33-36.

Huntting, M.T., Bennett, W.A.G., Livingston, V.E., Jr., and Moen, W.S., 1961, Geologic map of Washington, Washington Division of Mines and Geology, scale 1:500,000.

Huyck, H.L.O., 1990, When is a metalliferous black shale not a black shale?, in Grauch, R.I., and Huyck, H.L.O., eds., Metalliferous black shales and related ore deposits-Proceedings, 1989 United States Working Group Meeting, International Geological Correlation Program Project 254: U.S. Geological Survey Circular 1958, p. 42-56.

Iowa Geological Survey, 1969, Geologic map of Iowa: Iowa Geological Survey, scale 1:500,000.

Isachsen, Y.W., and Fisher, D.W., 1970, Geologic map of New York, Adirondack sheet: New York State Museum and Science Service Map and Chart Series No. 15, scale 1:250,000.

Jennings, C.W., 1958, Geologic map of California, San Luis Obispo sheet: California Division of Mines, scale 1:250,000. 1959, Geologic map of California, Santa Maria sheet: California Division of Mines, scale 1:250,000.

1962, Geologic map of California, Long Beach sheet: California Division of Mines and Geology, scale 1:250,000.
Jennings, C.W., and Burnett, J.L., 1961, Geologic map of California, San Francisco sheet: California Division of Mines, scale $1: 250,000$.

Jennings, C.W., and Strand, R.G., 1958, Geologic map of California, Santa Cruz sheet: California Division of Mines, scale $1: 250,000$.

1960, Geologic map of California, Ukiah sheet: California Division of Mines, scale 1:250,000.

1969, Geologic map of California, Los Angeles sheet: California Division of Mines and Geology, scale 1:250,000.

Jessey, D.R., 1983, The occurrence of nickel and cobalt in the southeast Missouri mining district, in Kisvarsanyi, Geza, Grant, S.K., Pratt, W.P., and Koenig, J.W., eds., International conference of Mississippi Valley type lead-zinc deposits: Rolla, University of Missouri, p. 145-154.

Jillson, W.R., 1929, Geologic map of Kentucky: Kentucky Geological Survey, scale 1:500,000.

Johnson, G.H., and Keller, S.J., 1972, Geologic map of the $1^{\circ} \times 2^{\circ}$ Fort Wayne quadrangle, Indiana, Michigan, and Ohio, showing bedrock and unconsolidated deposits: Indiana Geological Survey, Regional Geologic Map No. 8, scale 1:250,000.

Johnson, K.S., 1976, Permian copper shales of southwestern Oklahoma, in Johnson, K.S., and Croy, R.L., eds., Stratiform copper deposits of the midcontinent region, a symposium: Oklahoma Geological Survey Circular 77, p. 3-14.

-1978, Stratigraphy and mineral resources of Guadalupian and Ochoan rocks in the Texas panhandle and western Oklahoma: New Mexico Bureau of Mines and Mineral Resources Circular 159, p. 57-62.

Johnson, K.S., and Croy, R.L., eds., 1976, Stratiform copper deposits of the midcontinent region, a symposium: Oklahoma Geological Survey Circular 77, 99 p.

Jowett, E.C., 1986, Genesis of Kupferschiefer Cu-Ag deposits by convective flow of Rotliegende brines during Triassic rifting: Economic Geology, v. 81, p. 1823-1837.

Jowett, E.C., Rydzewski, Andrzej, and Jowett, R.J., 1987, The Kupferschiefer $\mathrm{Cu}-\mathrm{Ag}$ ore deposits in Poland: a re-appraisal of the evidence of their origin and presentation of a new genetic model: Canadian Journal of Earth Sciences, v. 24, p. 2016-2037.

Kalliokoski, Jorma, Langford, F.F., and Ojakangas, R.W., 1978, Criteria for uranium occurrences in Saskatchewan and Australia as guides to favorability for similar deposits in the United States: Development of Geology and Geological Engineering, Michigan Technological University, Houghton, MI 49931, and U.S. Department of Energy, Grand Junction Office, GJBX-114, 480 p.

Karlstrom, K.E., and Houston, R.S., 1979, Stratigraphy and uranium potential of early Proterozoic metasedimentary rocks in the Medicine Bow Mountains, Wyoming: Wyoming Geological Survey Report of Investigation 13, $45 \mathrm{p}$.

Kasner Group, 1987, Working together to develop Canada's natural resources: Canadian Institute of Mining Bulletin, v. 80, p. 17 [advertisement].

King, P.B., and Beikman, H.M., 1974, Geologic map of the United States: U.S. Geological Survey, scale 1:2,500,000.

Kirkham, R.V., 1984, Volcanic redbed copper, in Eckstrand, R.O., ed., Canadian mineral deposit types: a geological synopsis: Geological Survey of Canada Report 36, p. 37. 
1989, Distribution, settings and genesis of sediment-hosted stratiform copper deposits, in Boyle, R.W., Brown, A.C., Jefferson, C.W., Jowett, E.C., and Kirkham, R.V., eds., Sediment-hosted stratiform copper deposits: Geological Association of Canada Special Paper 36, p. 3-38.

Kisvarsanyi, Geza, 1977, The role of the Precambrian igneous basement in the formation of the stratabound lead-zinc-copper deposits in southeast Missouri: Economic Geology, v. 72 , p. $435-442$.

Koenig, J.B., 1963, Geologic map of California, Santa Rosa sheet: California Division of Mines and Geology, scale 1:250,000.

Kucha, H., 1982, Platinum-group metals in the Zechstein copper deposits, Poland: Economic Geology, v. 77, p. 1578-1591.

Kucha, Henryk, 1983, Precious metal bearing shale from Zechstein copper deposits, Lower Silesia, Poland: Institute of Mining and Metallurgy Transactions, Sec. B, p. B72-B79.

LaPoint, D.J., 1976, A comparison of selected sandstone copper deposits in New Mexico, in Johnson, K.S., and Croy, R.L., eds., Stratiform copper deposits of the midcontinent region, a symposium: Oklahoma Geological Survey Circular 77, p. 80-96.

1979, Geology, geochemistry, and petrology of sandstone copper deposits in New Mexico: Boulder, University of Colorado, $\mathrm{Ph} . \mathrm{D}$. dissertation, $332 \mathrm{p}$.

1989, A model for the diagenetic formation of sandstone copper deposits in sedimentary rocks of Permian and Triassic age, in New Mexico, U.S.A., in Boyle, R.W., Brown, A.C., Jefferson, C.W., Jowett, E.C., and Kirkham, R.V., eds., Sediment-hosted stratiform copper deposits: Geological Association of Canada Special Paper 36, p. 357-370.

Lawton, D.E., and others, 1976, Geologic map of Georgia: Georgia Geological Survey, scale 1:500,000.

Leventhal, J.S., 1989, Geochemistry of minor and trace elements of 22 core samples from the Monterey Formation and related rocks in the Santa Maria basin, California: U.S. Geological Survey Bulletin 1581-B, 11 p.

Lewis, J.V., 1907, Copper deposits in the New Jersey Triassic: Economic Geology, v. 2, p. 242-257.

Lewis, J.V., and Kümmel, H.B., (revised by M.E. Johnson), 1950, Geologic map of New Jersey: New Jersey Department of Conservation and Economic Development, scale 1:250,000.

Link, P.K., and Mahoney, J.B., 1989, Stratigraphic setting of sediment-hosted mineralization in the eastern Hailey $1^{\circ} \times 2^{\circ}$ quadrangle, Blaine, Custer, and Camas Counties, south-central Idaho, in Winkler, G.R., Soulliere, S.J., Worl, R.G., and Johnson, K.M., eds., Geology and mineral deposits of the Hailey and western Idaho Falls $1^{\circ}$ by $2^{\circ}$ quadrangles, Idaho: U.S. Geological Survey Open-File Report 89-639, p. 53-69.

Love, J.D., and Christiansen, A.C., 1985, Geologic map of Wyoming: U.S. Geological Survey, scale 1:500,000.

Lydon, P.A., Gay, T.E., Jr., and Jennings, C.W., 1960, Geologic map of California, Westwood sheet: California Division of Mines, scale 1:250,000.

Macdonald, A.J., 1987, Ore deposit models \#12. The platinum group element deposits: classification and genesis: Geoscience Canada, v. 14 , no. 3, p. 155-166.

Matthews, R.A., and Burnett, J.L., 1965, Geologic map of California, Fresno sheet: California Division of Mines and Geology, scale $1: 250,000$.
Maughan, E.K., 1984, Geological setting and some geochemistry of petroleum source rocks in the Permian Phosphoria Formation, in Woodward, Jane, Meissner, F.F., and Clayton, J.R., eds., Hydrocarbon source rocks of the greater Rocky Mountain region: Denver, Colo., Rocky Mountain Association of Geologists, p. 281-294.

McCauley, J.F., 1961, Uranium in Pennsylvania: Pennsylvania Geological Survey Bulletin M43, $71 \mathrm{p}$.

McDowell, R.C., Grabowski, G.J., Jr., and Moore, S.L., 1981, Geologic map of Kentucky: U.S. Geological Survey and Kentucky Geological Survey, scale 1:250,000.

McKee, E.D., and Gutschick, R.C., 1969, History of the Redwall Limestone of northern Arizona: Geological Society of America Memoir 114, 726 p.

McKelvey, V.E., 1955, Search for uranium in the United States: U.S. Geological Survey Bulletin 1030-A, p. 1-64.

Meissner, F.F., Woodward, Jane, and Clayton, J.L., 1984, Stratigraphic relationships and distribution of source rocks in the greater Rocky Mountain region, in Woodward, Jane, Meissner, F.F., and Clayton, J.R., eds., Hydrocarbon source rocks of the greater Rocky Mountain region: Denver, Colo., Rocky Mountain Association of Geologists, p. 1-34.

Mertie, J.B., Jr., 1969, Economic geology of the platinum metals: U.S. Geological Survey Professional Paper 630, 120 p.

Miser, H.D., and others, 1954, Geologic map of Oklahoma: U.S. Geological Survey and Oklahoma Geological Survey, scale 1:500,000.

Missouri Geological Survey, 1979, Geologic map of Missouri: Missouri Geological Survey, scale 1:500,000.

Modreski, P.J., 1985, Stratabound cobalt-copper deposits in the Middle Proterozoic Yellowjacket Formation in and near the Challis quadrangle, in McIntyre, D.H., ed., Symposium on the geology and mineral deposits of the Challis $1^{\circ} \times 2^{\circ}$ quadrangle, Idaho: U.S. Geological Survey Bulletin 1658-R, p. 201-221.

Moore, R.C., and Landes, K.K., 1937, Geologic map of Kansas: State Geological Survey of Kansas, scale 1:500,000.

Morey, G.B., Sims, P.K., Cannon, W.F., Mudrey, M.G., Jr., and Southwick, D.L., 1982, Geologic map of the Lake Superior region, Minnesota, Wisconsin, and northern Michigan: Minnesota Geological Survey Map S-13, scale 1:1,000,000.

Morrison, S.J., and Parry, W.T., 1986, Formation of carbonatesulfate veins associated with copper ore deposits from saline basin brines, Lisbon Valley, Utah: fluid inclusions and isotopic evidence: Economic Geology, v. 81, p. 1853-1866.

Morton, R.D., 1976, The Western and Northern Australian uranium deposits-exploration guides or exploration deterrents for Saskatchewan?, in Dunn, C.E., ed., Uranium in Saskatchewan: Saskatchewan Geological Society Special Publication 3, p. 211-254.

Mosier, D.L., 1986, Grade and tonnage model of unconformity U-Au, in Cox, D.P., and Singer, D.A., eds., Mineral deposit models: U.S. Geological Survey Bulletin 1693, p. 249-250.

Mosier, D.L., and Bliss, J.D., 1992, Introduction and overview of mineral deposit modeling, in Bliss, J.D., ed., Developments in mineral deposit modeling: U.S. Geological Survey Bulletin 2004, p. 1-5.

Mosier, D.L., and Briskey, J.A., 1986, Grade and tonnage model of southeast Missouri $\mathrm{Pb}-\mathrm{Zn}$ and Appalachian $\mathrm{Zn}$ deposits, 
in Cox, D.P., and Singer, D.A., eds., Mineral deposit models: U.S. Geological Survey Bulletin 1693, p. 224-226.

Mosier, D.L., and Page, N.J, 1988, Descriptive and grade-tonnage models of volcanogenic manganese deposits in oceanic environments-a modification: U.S. Geological Survey Bulletin $1811,28 \mathrm{p}$.

Mosier, D.L., Singer, D.A., and Cox, D.P., 1986, Grade and tonnage model of sediment-hosted $\mathrm{Cu}$, in $\mathrm{Cox}$, D.P., and Singer, D.A., eds., Mineral deposit models: U.S. Geological Survey Bulletin 1693, p. 206-208.

Mountain, B.W., and Wood, S.A., 1988a, Chemical controls on the solubility, transport, and deposition of platinum and palladium in hydrothermal solutions: a thermodynamic approach: Economic Geology, v. 83, p. 492-510.

Mountain, B.W., and Wood, S.A., 1988b, Solubility and transport of platinum-group elements in hydrothermal solution: thermodynamic and physical chemical constraints, in Prichard, H.H., Potts, P.J., Bowles, J.F.W., and Cribb, S.J., eds., Proceedings of the symposium Geo-Platinum 87 held at the Open University, Milton-Keynes, Great Britain, April 22-23, 1987, Basking, Essex, Great Britain, Elsevier, p. 57-82.

Naldrett, A.J., 1981, Platinum-group element deposits, in Cabri, L.J., ed., Platinum-group elements: mineralogy, geology, recovery: Canadian Institute of Mining and Metallurgy Special Volume 23, p. 197-231.

Nash, J.T., and Hahn, G.A., 1986, Volcanogenic character of sediment-hosted $\mathrm{Co}-\mathrm{Cu}$ deposits in the Blackbird mining district, Lemhi County, Idaho-an interim report: U.S. Geological Survey Open-File Report 86-430, 29 p.

1989, Stratabound $\mathrm{Co}-\mathrm{Cu}$ deposits and mafic volcaniclastic rocks in the Blackbird mining district, Lemhi County, Idaho, in Boyle, R.W., Brown, A.C., Jefferson, C.W., Jowett, E.C., and Kirkham, R.V., eds., Sediment-hosted stratiform copper deposits: Geological Association of Canada Special Paper 36, p. 339-356.

Needham, R.S., 1987, A review of mineralization in the South Alligator Conservation Zone: Bureau of Mineral Resources, Australia, Record 1987/52, 24 p.

Needham, R.S., and Stuart-Smith, P.G., 1987, Coronation Hill UAu mine, South Alligator Valley, Northern Territory: an epigenetic sandstone-type deposit hosted by debris-flow conglomerate: Bureau of Mineral Resources Journal of Australian Geology and Geophysics, v. 10, p. 121-131.

Newland, D.H., ed., 1932, The Paleozoic stratigraphy of New York: International Geological Congress, 16th, Washington, D.C., Guidebook 4: Excursion A-4, p. 1-24.

Nininger, R.D., 1954, Minerals for atomic energy: New York, D. Van Nostrand Co., Inc., $367 \mathrm{p}$.

North Carolina Division of Mineral Resources, 1958, Geologic map of North Carolina: North Carolina Division of Mineral Resources, scale 1:500,000.

Nutt, C.J., 1981, A model of uranium mineralization in the Dripping Spring Quartzite, Gila County, Arizona: U.S. Geological Survey Open-File Report 81-524, 49 p.

Nutt, C.J., Frishman, David, Grauch, R.I., Nash, J.T., and Ludwig, K.R., 1986, Controls on distribution of ore in so-called "unconformity-type" uranium deposits in Australia and implications for United States uranium resources [abs.], in Carter, L.M.H., ed., USGS research on energy resources-1986, program and abstracts: U.S. Geological Survey Circular 974, p. $45-46$.

Ong, H.L., and Swanson, V.E., 1969, Natural organic acids in the transportation, deposition, and concentration of gold: Colorado School of Mines Quarterly, v. 64, p. 395-425.

Orris, G.J., and Bliss, J.D., 1986, Grade and tonnage model of placer Au-PGE, in Cox, D.P., and Singer, D.A., eds., Mineral deposit models: U.S. Geological Survey Bulletin 1693, p. 261-264.

Orth, C.J., Quintana, L.R., Gilmore, J.S., Barrick, J.E., Haywa, J.N., and Spesshardt, S.A., 1988, Pt-group metal anomalies in the Lower Mississippian of southern Oklahoma: Geology, v. 16, p. $627-630$.

Page, N.J, and Gray, Floyd, 1986, Descriptive model of Alaskan PGE, in Cox, D.P., and Singer, D.A., eds., Mineral deposit models: U.S. Geological Survey Bulletin 1693, p. 49-50.

Parnell, John, 1988, Native platinum in pyrobitumen from Fonda, New York: American Mineralogist, v. 73, p. 1170-1171.

Peck, D.L., 1961, Geologic map of Oregon west of the 121st meridian: U.S. Geological Survey Miscellaneous Geologic Investigations Map I-325, scale 1:500,000.

Pettijohn, F.J., 1975, Sedimentary rocks, 3d edition: San Francisco, Calif., Harper \& Row, Publishers, p. 282-284.

Pignolet, Susanne, and Hagni, R.D., 1983, Cobalt-nickel mineralization associated with lead-zinc-copper mineralization in the Mississippi Valley-type deposits at Fredericktown, Missouri, in Kisvarsanyi, Geza, Grant, S.K., Pratt, W.P., and Koenig, J.W., eds., International conference on Mississippi Valley type lead-zinc deposits: Rolla, University of Missouri, p. 187-194.

Poole, F.G., and Claypool, G.E., 1984, Petroleum source rock potential and oil correlation in the Great Basin, in Woodward, Jane, Meissner, F.F., and Clayton, J.R., eds., Hydrocarbon source rocks of the greater Rocky Mountain region: Denver, Colo., Rocky Mountain Association of Geologists, p. $179-230$.

Poole, F.G., and Desborough, G.A., 1980, Oil and metals in Ordovician and Devonian kerogenous marine strata of central Nevada: American Association of Petroleum Geologists Bulletin, v. 64, p. 717.

Pretorius, D.A., 1976, The nature of the Witwatersrand gold-uranium deposits, in Wolf, K.H., ed., Handbook of stratabound and stratiform ore deposits, v. 7: Amsterdam, Elsevier, p. 29-88.

1981, Gold and uranium in quartz-pebble conglomerates: Economic Geology 75th Anniversary Volume, p. 117-138.

Price, J.G., Henry, C.D., Standen, A.R., and Posey, J.S., 1985, Origin of silver-copper-lead deposits in red-bed sequences of Trans-Pecos Texas: Tertiary mineralization in Precambrian, Permian, and Cretaceous sandstones: Texas Bureau of Economic Geology Report of Investigations 145, 65 p.

Raicevic, D., and Cabri, L.J., 1976, Mineralogy and concentrations of $\mathrm{Au}$ - and Pt-bearing placers from the Tulameen River area in British Columbia: Canadian Institute of Mining and Metallurgy Bulletin, v. 49, no. 770, p. 111-119.

Rainer, Zangerl, and Richardson, E.S., Jr., 1963, The paleoecological history of two Pennsylvanian black shales: Fieldiana: Geology Memoirs, v. 4, 352 p.

Redden, J.A., 1987, Uraniferous Early Proterozoic conglomerates of the Black Hills, South Dakota, USA, in Uranium deposits 
in Proterozoic quartz-pebble conglomerates: Vienna, Austria, International Atomic Energy Agency, p. 75-97.

Rember, W.C., and Bennett, E.H., 1979a, Geologic map of the Challis quadrangle, Idaho: Idaho Bureau of Mines and Geology Geologic Map Series, scale 1:250,000.

1979b, Geologic map of the Dubois quadrangle, Idaho: Idaho Bureau of Mines and Geology Geologic Map Series, scale $1: 250,000$.

1979c, Geologic map of the Hailey quadrangle, Idaho: Idaho Bureau of Mines and Geology Geologic Map Series, scale 1:250,000.

1979d, Geologic map of the Idaho Falls quadrangle, Idaho: Idaho Bureau of Mines and Geology Geologic Map Series, scale 1:250,000.

Reynolds, S.J., 1988, Geologic map of Arizona: Arizona Geological Survey in cooperation with the U.S. Geological Survey, Map 26, scale 1:1,000,000.

Rickard, L.V., and Fisher, D.W., 1970a, Geologic map of New York, Finger Lakes sheet: New York State Museum and Science Service Map and Chart Series No. 15, scale 1:250,000.

1970b, Geologic map of the New York, Niagara sheet: New York State Museum and Science Service Map and Chart Series, No. 15, scale 1:250,000.

Ripley, E.M., Lambert, M.W., and Berendsen, Pieter, 1980, Mineralogy and paragenesis of red-bed copper mineralization in the lower Permian of south-central Kansas: Economic Geology, v. 75 , p. $722-729$.

Ripley, E.M., and Nicol, D.L., 1981, Sulfur isotopic studies of Archean slate and graywacke from northern Minnesota: evidence for the existence of sulfate reducing bacteria: Geochimica et Cosmochimica Acta, v. 45, p. 839-846.

Robertson, D.S., and Lattanzi, C.R., 1972, Uranium deposits of Canada: Geoscience Canada, v. 1, no. 2, p. 8-19.

Robinson, G.R., Jr., and Froelich, A.J., eds., 1985, Proceedings of the second U.S. Geological Survey workshop on the early Mesozoic basins of the eastern United States: U.S. Geological Survey Circular 946, 147 p.

Robinson, G.R., Jr., and Sears, C.M., 1988, Inventory of metal mines and occurrences associated with the early Mesozoic basins of the eastern United States-summary tables, in Froelich, A.J., and Robinson, G.R., Jr., eds., Studies of the early Mesozoic basins of the eastern United States: U.S. Geological Survey Bulletin 1776, p. 265-303.

Rodgers, John, 1985, Bedrock geologic map of Connecticut: Connecticut Geological and Natural History Survey and U.S. Geological Survey, scale 1:125,000.

Rogers, T.H., 1965, Geologic map of California, Santa Ana sheet: California Division of Mines and Geology, scale $1: 250,000$.

1966, Geologic map of California, San Jose sheet: California Division of Mines and Geology, scale 1:250,000.

1967, Geologic map of California, San Bernardino sheet: California Division of Mines and Geology, scale 1:250,000.

Rose, A.W., 1976, The effect of cuprous chloride complexes on the origin of red-bed copper and related deposits: Economic Geology, v. 71, p. 1036-1048.

1989, Mobility of copper and other heavy metals in sedimentary environments, in Boyle, R.W., Brown, A.C., Jefferson, C.W., Jowett, E.C., and Kirkham, R.V., eds., Sediment- hosted stratiform copper deposits: Geological Association of Canada Special Paper 36, p. 97-110.

Rose, A.W., Smith, A.T., Lustwerk, R.L., Ohmoto, H., and Hoy, L.D., 1986, Geochemical aspects of stratiform and red-bed copper deposits in the Catskill Formation (Pennsylvania, USA) and Redstone area (Canada). Sequence of mineralization in sediment-hosted copper deposits (Part 3), in Friedrich, G.H., Genkin, A.D., Naldrett, A.J., Ridge, J.D., Sillitoe, R.H., and Vokes, F.M., eds., Geology and metallogeny of copper deposits: New York, Springer-Verlag, p. 412-421.

Ross, C.P., 1963, The Belt Series in Montana: U.S. Geological Survey Professional Paper 345, $122 \mathrm{p}$.

Ross, C.P., Andrews, D.A., and Witkind, I.J., 1955, Geologic map of Montana: U.S. Geological Survey and Montana Bureau of Mines and Geology, scale 1:500,000.

Ross, C.P., and Forrester, J.D., 1947, Geologic map of the state of Idaho: U.S. Geological Survey and Idaho Bureau of Mines and Geology, scale 1:500,000.

Ruch, R.R., Russell, S.J., Malhotra, R., Steele, J.D., Bhagwat, S.B., Dreher, G.B., Cahill, R.A., Frost, J.K., Harvey, R.D., and Ashby, J.F., 1979, Determination of valuable metals in liquefaction process residues: Final report. Prepared for the U.S. Department of Energy, Report FE-8004-42, 187 p.

Schneider, A.F., and Keller, S.J., 1970, Geologic map of the $1^{\circ} \times 2^{\circ}$ Chicago quadrangle, Indiana, Illinois, and Michigan, showing bedrock and unconsolidated deposits: Indiana Geological Survey, Regional Geologic Map No. 4, scale $1: 250,000$.

Schultz, R.B., and Maynard, J.B., 1990, Midcontinent Virgilian (Upper Pennsylvanian) black shales in eastern Kansas, in Grauch, R.I., and Huyck, H.L.O., eds., Metalliferous black shales and related ore deposits-Proceedings, 1989 United States Working Group Meeting, International Geological Correlation Program Project 254: U.S. Geological Survey Circular 1958, p. 68-78.

Seasor, R.W., and Brown, A.C., 1989, Syngenetic and diagenetic concepts at the White Pine copper deposit Michigan, in Boyle, R.W., Brown, A.C., Jefferson, C.W., Jowett, E.C., and Kirkham, R.V., eds., Sediment-hosted stratiform copper deposits: Geological Association of Canada Special Paper 36, p. 257-268.

Shaffer, N.R., and Leininger, R.K., 1981, Heavy metals in organic-rich New Albany Shale of Indiana [abs.]: Geological Society of America Abstracts with Programs, v. 13, no. 7, p. 551.

Shride, A.F., 1967, Younger Precambrian geology in southern Arizona: U.S. Geological Survey Professional Paper 566, 89 p.

Singer, D.A., and Page, N.J, 1986, Grade and tonnage model of placer PGE-Au, in Cox, D.P., and Singer, D.A., eds., Mineral deposit models: U.S. Geological Survey Bulletin 1693, p. 265-269.

Smith, A.R., 1965, Geologic map of California, Bakersfield sheet, California Division of Mines and Geology, scale $1: 250,000$.

Smith, G.E., 1974, Depositional systems, San Angelo Formation (Permian), north Texas-facies control of red-bed copper mineralization: Texas Bureau of Economic Geology Report of Investigations $80,84 \mathrm{p}$.

Smith, J.G., Page, N.J, Johnson, M.G., Moring, B.C., and Gray, Floyd, 1982, Preliminary geologic map of the Medford $1^{\circ}$ 
3336 by $2^{\circ}$ quadrangle, Oregon and California: U.S. Geological Survey Open-File Report 82-955, scale 1:250,000.

Smith, R.C., II, Berkheiser, S.W., Jr., and Hoff, D.T., 1988, Locations and analyses of selected early Mesozoic copper occurrences in Pennsylvania, in Froelich, A.J., and Robinson, G.R., Jr., eds., Studies of the early Mesozoic basins of the eastern United States: U.S. Geological Survey Bulletin 1776, p. 320332.

Smoot, J.P., and Robinson, G.R., Jr., 1988, Sedimentology of stratabound base-metal occurrences in the Newark Supergoup, in Froelich, A.J., and Robinson, G.R., Jr., eds., Studies of the early Mesozoic basins of the eastern United States: U.S. Geological Survey Bulletin 1776, p. 356-376.

Snyder, F.G., and Gerdemann, P.E., 1968, Geology of the southeast Missouri lead district, in Ridge, J.D., ed., Ore deposits in the United States 1933/1967, Graton-Sales Volume I: American Institute of Mining, Metallurgical, and Petroleum Engineers, p. 326-358.

Soulé, J.H., 1956, Reconnaissance of the "red bed" copper deposits in southeastern Colorado and New Mexico: U.S. Bureau of Mines Information Circular 7740, $74 \mathrm{p}$.

Spoljaric, Nenad, and Jordan, R.R., 1966, Generalized geologic map of Delaware: Delaware Geological Survey, scale $1: 300,000$.

Stewart, J.H., and Carlson, J.E., 1978, Geologic map of Nevada: U.S. Geological Survey, scale 1:500,000.

Strand, R.G., 1962, Geologic map of California, Redding sheet: California Division of Mines and Geology, scale 1:250,000.

1963, Geologic map of California, Weed sheet: California Division of Mines and Geology, scale 1:250,000.

1967, Geologic map of California, Mariposa sheet: California Division of Mines and Geology, scale 1:250,000.

Strand, R.G., and Koenig, J.B., 1965, Geologic map of California, Sacramento sheet: California Division of Mines and Geology, scale 1:250,000.

Strauss, H., 1986, Carbon and sulfur isotopes in Precambrian sediments from the Canadian Shield: Geochimica et Cosmochimica Acta, v. 50, p. 2653-2662.

Stuckley, J.L., and Conrad, S.G., 1958, Explanatory text for geologic map of North Carolina: North Carolina Division of Mineral Resources Bulletin 71, p. 44.

Sutphin, H.B., and Wenrich, K.J., 1983, Structural control of breccia pipes on the southern Marble Plateau, Arizona: U.S. Geological Survey Open-File Report 83-908, 6 p.

Sweeney, M., Turner, P., and Vaughan, D.J., 1986, Stable isotope and geochemical studies of the role of early diagenesis in ore formation, Konkola Basin, Zambian Copper Belt: Economic Geology, v. 81 , p. $1838-1852$.

Tankard, A.J., Jackson, M.P.A., Eriksson, K.A., Hobday, D.K., Hunter, D.R., and Minter, W.E.Z., 1982, Chapter 4: The golden Proterozoic, in Crustal evolution of southern Africa: 3.8 billion years of Earth history: New York, Springer-Verlag, p. 115-150.

Thacker, J.L., and Anderson, K.H., 1977, The geologic setting of the southeast Missouri lead district-regional geologic history, structure and stratigraphy: Economic Geology, v. 72, p. 339-348.

Tooker, E.W., 1980, Preliminary map of copper provinces in the conterminous United States: U.S. Geological Survey OpenFile Report 79-576-D, scale 1:5,000,000.
Tourtelot, E.B., 1970, Selected annotated bibliography of minorelement content of marine black shales and related sedimentary rocks, 1930-1965: U.S. Geological Survey Bulletin 1293, $118 \mathrm{p}$.

Tweto, Ogden, 1979, Geologic map of Colorado: U.S. Geological Survey and Geological Survey of Colorado, scale $1: 500,000$.

Van der Flier-Keller, Elizabeth, 1990, Platinum group elements in Canadian coal: Energy Sources, v. 12, p. 225-238.

1991, Platinum-group elements in Tulameen coal, British Columbia, Canada: Economic Geology, v. 86, p. 387-395.

Van der Flier-Keller, Elizabeth, and Fyfe, W.S., 1987, Geochemistry of two Cretaceous coal-bearing sequences: James Bay lowlands, northern Ontario, and Peace River basin, northeast British Columbia: Canadian Journal of Earth Sciences, v. 24, p. 1038-1052.

Van der Flier-Keller, Elizabeth, and Goodarzi, F., 1988, Platinum group elements in the Tulameen coal deposit, southwestern British Columbia [abs.]: Geological Association of Canada Program with Abstracts, v. 13, p. A128.

Vine, J.D., and Tourtelot, E.B., 1970, Geochemistry of black shale deposits-a summary report: Economic Geology, v. 65, p. 253-272.

Walker, G.W., 1977, Geologic map of Oregon east of the 121st meridian: U.S. Geological Survey Miscellaneous Geologic Investigations Map I-902, scale 1:500,000.

Waugh, T.C., and Brady, L.L., 1976, Copper occurrences associated with Permian rocks in south-central Kansas, in Johnson, K.S., and Croy, R.L., eds., Stratiform copper deposits of the midcontinent region, a symposium: Oklahoma Geological Survey Circular 77, p. 76-79.

Wayne, W.J., Johnson, G.H., and Keller, S.J., 1966, Geologic map of the $1^{\circ} \times 2^{\circ}$ Danville quadrangle, Indiana and Illinois, showing bedrock and unconsolidated deposits: Indiana Geological Survey, Regional Geologic Map No. 2, scale $1: 250,000$.

Wells, J.H., 1969, Placer examination, principles, and practice: U.S. Bureau of Land Management Technical Bulletin 4, 209 p.

Wenrich, K.J., 1985, Mineralization of breccia pipes in northern Arizona: Economic Geology, v. 80, p. 1722-1735.

Wenrich, K.J., Van Gosen, B.S., Balcer, R.A., Scott, J.H., Mascarenas, J.F., Bedinger, G.M., and Burmaster, Betsi, 1988, A mineralized breccia pipe in Mohawk Canyon, Arizona-lithologic and geophysical logs: U.S. Geological Survey Bulletin $1683,66 \mathrm{p}$.

Wenrich, K.J., Van Gosen, B.S., and Sutphin, H.B., 1990, Genesis and distribution of uraninite in solution-collapse breccia pipes, northwestern Arizona: U.S. Geological Survey Circular 1060, p. 86-91.

Wenrich, K.J., Verbeek, E.R., Sutphin, H.B., Van Gosen, B.S., and Modreski, P.J., 1987, The Apex Mine, Utah-a Colorado Plateau-type solution-collapse breccia pipe: U.S. Geological Survey Circular 995, p. 73-74.

Wewerka, E.M., Williams, J.M., Vanderborgh, N.E., Harmon, A.W., Wagner, P., Wanek, P.L., and Olsen, J.D., 1978, Trace element characterization of coal wastes-second annual progress report, prepared for the U.S. Department of Energy (LA-7360-PR) and Environmental Protection Agency (EPA600/7-78-028a), 144 p. 
Wherry, E.T., 1908, The Newark copper deposits of southeastern Pennsylvania: Economic Geology, v. 3, p. 726-738.

Wilde, A.R., Bloom, M.S., and Wall, V.J., 1989, Transport and deposition of gold, uranium, and platinum-group elements in unconformity-related uranium deposits: Economic Geology Monograph 6, p. 637-650.

Willman, H.B., and others, 1967, Geologic map of Illinois: Illinois State Geological Survey, scale 1:500,000.

Wilson, E.D., Moore, R.T., and Cooper, J.R., 1969, Geologic map of Arizona: Arizona Bureau of Mines and U.S. Geological Survey, scale 1:500,000.

Winston, Don, 1986, Generalized geologic map of the Belt-Purcell Basin, Montana, Idaho, Washington, and Wyoming, USA; Alberta and British Columbia, Canada, in Roberts, S.M., ed., Belt Supergroup: Montana Bureau of Mines and Geology Special Paper 94, pl. 1, scale appprox. 1:1,250,000.

Wood, S.A., Mountain, B.W., and Fenlon, B.J., 1989, Thermodynamic constraints on the solubility of platinum and palladi- um in hydrothermal solutions: reassessment of hydroxide, bisulfide, and ammonia complexing: Economic Geology, v. 84 , p. $2020-2028$.

Yeend, W.E., 1986, Descriptive model of placer Au-PGE, in Cox, D.P., and Singer, D.A., eds., Mineral deposit models: U.S. Geological Survey Bulletin 1693, p. 261.

Yeend, W.E., and Page, N.J, 1986, Descriptive model of placer PGE-Au, in Cox, D.P., and Singer, D.A., eds., Mineral deposit models: U.S. Geological Survey Bulletin 1693, p. 265 .

Zen, E-An, ed., 1983, Bedrock geologic map of Massachusetts: U.S. Geological Survey in cooperation with the Commonwealth of Massachusetts, Department of Public Works, scale 1:250,000.

Zientek, M.L., Allcott, G.H., Page, N.J, and Menzie, W.D., 1988, Opportunities for a platinum-group-element resource appraisal of the United States: U.S. Geological Survey OpenFile Report 88-254, 14 p. 


\section{APPENDIX-LIST OF PGE-BEARING AND SOME LESS COMMON MINERALS USED IN TEXT AND THEIR IDEAL CHEMICAL COMPOSITIONS WHERE KNOWN}

$\begin{array}{ll}\text { Braggite } & (\mathrm{Pt}, \mathrm{Pd}) \mathrm{S} \\ \text { Bravoite } & (\mathrm{Ni}, \mathrm{Fe}) \mathrm{S}_{2} \\ \text { Carrollite } & \mathrm{Cu}\left(\mathrm{Co}, \mathrm{Ni}_{2} \mathrm{~S}_{4}\right. \\ \text { Cooperite } & \mathrm{PtS} \\ \text { Fletcherite } & (\mathrm{Cu}, \mathrm{Ni}, \mathrm{Co})_{3} \mathrm{~S}_{4} \\ \text { Geversite } & \mathrm{PtSb}_{2} \\ \text { Haycockite } & \mathrm{Cu}_{4} \mathrm{Fe}_{5} \mathrm{~S}_{8} \\ \text { Hollingworthite } & \mathrm{RhAsS} \\ \text { Iridarsenite } & \mathrm{IrAs}_{2} \\ \text { Iridian ruthenium } & (\mathrm{Ru}, \mathrm{Ir}) \\ \text { Isoferroplatinum } & \mathrm{Pt}_{3} \mathrm{Fe} \\ \text { Laurite } & \mathrm{RuS}_{2} \\ \text { Michenerite } & \mathrm{PdBiTe} \\ \text { Moncheite } & \mathrm{PtTe}_{2} \\ \text { Mooihoekite } & \mathrm{Cu}_{9} \mathrm{Fe}_{9} \mathrm{~S}_{16} \\ \text { Oosterboschite } & \left(\mathrm{Pd}, \mathrm{Cu}_{7} \mathrm{Se}_{5}\right. \\ \text { Polydymite } & \mathrm{Ni}_{3} \mathrm{~S}_{4} \\ \text { Ruthenarsenite } & \mathrm{RuAs}_{2} \\ \text { Ruthenian iridium } & (\mathrm{Ir}, \mathrm{Ru}) \\ \text { Ruthenosmiridium } & (\mathrm{Ir}, \mathrm{Os}, \mathrm{Ru}) \\ \text { Siegenite } & (\mathrm{Co}, \mathrm{Ni})_{3} \mathrm{~S}_{4} \\ \text { Sobolevskite } & \mathrm{Pd}_{1.01} 1.10 \mathrm{Bi} \\ \text { Sperrylite } & \mathrm{PtAs}_{2} \\ \text { Trogtalite } & \mathrm{CoSe}_{2} \\ \text { Vaesite } & \mathrm{NiS}_{2} \\ & \end{array}$

